\title{
Revisiting the Andean butterfly Eryphanis zolvizora group (Lepidoptera, Nymphalidae): one or several species?
}

\author{
Patrick BLANDIN ${ }^{1}$, Roger BRISTOW ${ }^{2}$, Andrew NEILD ${ }^{3}$, Juan Carlos DE SOUSA ${ }^{4}$, Yuvinka \\ GARECA $^{5}$ \& Blanca HUERTAS ${ }^{3,6}$ \\ ${ }^{1}$ Muséum National d'Histoire Naturelle, Entomologie, 57 rue Cuvier, 75005 Paris, France \\ E-mail: patrick.blandin@yahoo.fr (corresponding author) \\ 22 Sid Bank, Sid Lane, Sidmouth, Devon EX10 9AW, UK \\ E-mail: devonbristows@,btinternet.com \\ ${ }^{3}$ The Natural History Museum, Entomology Department, Cromwell Road, SW7 5BD, London, UK \\ E-mails: andrew.neild@blueyonder.co.uk, B.Huertas@nhm.ac.uk \\ ${ }^{4}$ Museo del Instituto de Zoología Agrícola, Facultad de Agronomía, Universidad Central de Venezuela, \\ Maracay, Apdo. 4579, Aragua, Venezuela \\ E-mail: mesosemia@yahoo.com \\ ${ }^{5}$ Museo de Historia Natural Alcide d’Orbigny, Entomologia, CP4324, Av. Potosi N 1458 (esq. Av. \\ América), Cochabamba, Bolivia \\ E-mail: yuvinkagar@yahoo.com
}

\footnotetext{
${ }^{1}$ urn:1sid:zoobank.org:author:F79EECF9-4E10-4826-BA99-01DE1EB0DD0E

${ }^{2}$ urn:1sid:zoobank.org:author:E9AD6AA1-2C47-4358-B606-0A84042D872D

${ }^{3}$ urn:lsid:zoobank.org:author:268E6AD0-5E7A-4073-B530-6CE39D963474

${ }^{4}$ urn:Isid:zoobank.org:author:68F7180E-1695-4716-B794-1900B02881D8

${ }^{5}$ urn:lsid:zoobank.org:author:17D6BF6C-A94B-4057-8057-454C3DF0CEA2

${ }^{6}$ urn:lsid:zoobank.org:author:F96FCD0A-4A22-4782-B077-4588E193134A
}

\begin{abstract}
Eryphanis zolvizora (Hewitson, 1877) is a rare Andean endemic butterfly, described from Bolivia, which has been historically classified either as a unique species, or as part of a group of three allopatric species from Bolivia, Ecuador and Colombia. In this paper, the group is revised using more than 200 specimens housed in 35 European and North and South American public and private collections. For the first time, the presence of the group in Western Ecuador and Venezuela is confirmed, and important data on Peruvian populations are provided. In some populations, individual variations of genitalia are observed. Nevertheless, male genitalia allow the distinction of four geographical groups. Considering also habitus characters, eight taxa are distinguished and considered to be subspecies, of which five are new: Eryphanis zolvizora inca ssp. nov., Eryphanis zolvizora chachapoya ssp. nov., Eryphanis zolvizora casagrande ssp. nov., Eryphanis zolvizora reyi ssp. nov., and Eryphanis zolvizora isabelae ssp. nov. In the present state of knowledge, these taxa are allopatric, except for a possible geographic overlap in central Peru, where data are insufficient to prove sympatry. The "several subspecies vs. several species" dilemma is discussed, considering its impact for conservation action and policies.
\end{abstract}

Keywords. Morphinae, Brassolini, Eryphanis zolvizora group, subspecies, taxonomic inflation. 
Blandin P., Bristow R., Neild A., Carlos de Sousa J., Gareca Y. \& Huertas B. 2014. Revisiting the Andean butterfly Eryphanis zolvizora group (Lepidoptera, Nymphalidae): one or several species? European Journal of Taxonomy 71: 1-66. http://dx.doi.org/10.5852/ejt.2014.71

\section{Introduction}

Within the butterfly family Nymphalidae, the sub-family Morphinae includes two tribes, the Morphini and Brassolini, both endemic to the Neotropical region. The former includes three genera as follows: Antirrhea Hübner, 1822, Caerois Hübner, 1819 and Morpho Fabricius, 1807, the last the most familiar, as it includes big and bright blue species that are emblematic of the Amazons. Following the most recent checklist (Casagrande 2004), the tribe Brassolini comprises 18 genera including the genus Caligo Hübner, 1819 (the well known large Owl butterflies). Since Fruhstorfer's review (1912), Stichel's catalogue (1932), and before Casagrande's checklist, five genera have been revised. More recently, Penz (2008) produced a phylogenetic review of the genus Eryphanis Boisduval, 1870. This genus was created for three species which have been included previously in the genus Pavonia Godart, 1824 (an invalid name according to Hemming 1967), or in the genus Caligo Hübner, 1819, or even in the genus Opsiphanes Doubleday, 1849. All species and subspecies currently recognized by Casagrande (2004) were known as early as 1912 (Fruhstorfer 1912). Between Stichel's catalogue and Casagrande's checklist, the only changes concern the name of a species, E. polyxena (Meerburgh, 1780) being a junior synonym of $E$. automedon (Cramer, 1775), and one subspecies included in the synonymy of another subspecies within E. polyxena. Moreover, Casagrande (2004) indicated no new subspecies or species to be described. Thus, the systematics of Eryphanis could be considered as well established at that time.

This consensus was challenged by Penz (2008), who studied male and female genitalia for the first time in this genus. She separated E. lycomedon (C. Felder \& R. Felder, 1862) from E. automedon, E. bubocula (Butler, 1872) from E. aesacus (Herrich-Schäffer, 1850), E. opimus Staudinger, 1887 from E. zolvizora (Hewitson, 1977), and together with DeVries she described E. greeneyi Penz \& DeVries, 2008, a new species close to E. zolvizora and E. opimus, these three species forming the Eryphanis zolvizora group.

Penz's work (2008) illustrates the taxonomic issues that arise with uncommon taxa distributed throughout immense regions such as the Neotropics. Should slightly different specimens collected in localities separated by hundreds or thousands of kilometres be considered as subspecies of a unique, polytypic species, or as distinct species? In such little-known groups, the delimitation of species is variable, depending on the 'lumper' or 'splitter' taxonomist's culture. The Eryphanis zolvizora group provides an interesting model to address this issue, which is a matter of intense debate (amongst many others, see for example Cracraft 2000 and James 2010). Beyond theoretical considerations on the nature of species, its evolutionary significance and its ecological role, practical questions arise: by raising subspecies to species level, splitters contribute to 'taxonomic inflation', with potential consequences on conservation policies (Isaac et al. 2004).

Eryphanis zolvizora (Hewitson, 1877) was described from two Bolivian specimens lacking precise locality data. Staudinger (1887) described Eryphanis opimus as a different species, based on three specimens, two from Manizales, central Cordillera, Colombia, and one from Chanchamayo, central Peru. Stichel $(1904 ; 1909)$ placed the two taxa in one species, and added specimens from Peru and Ecuador to the nominate sub-species. Fruhstorfer (1912) followed Stichel's classification. He indicated that E. $z$. zolvizora occurs in Peru, but without more precise locality details. Considering E. z. opimus, he wrote that in Ecuador and Peru a rather similar variety exists, which was not sufficiently studied, even though Staudinger outlined some weak differences. Stichel (1932) maintained that the nominate subspecies included the Peruvian and Ecuadorian populations, a position followed by D'Abrera (1987). Casagrande 
(2004), in her checklist, also recognised only one species, divided into the nominate subspecies and opimus as a Colombian subspecies. Penz (2008) showed that there are clear morphological differences in male genitalia between Bolivian and Colombian specimens, and she observed differences in female genitalia between Bolivian and Ecuadorian specimens. She also took into consideration wing shape and ornamentation. Despite having studied a very limited number of specimens $(3 \hat{\jmath}, 1$ ㅇ from Bolivia, $7 \hat{\jmath}, 4$ 우 from Ecuador, and only $1 \hat{\delta}$ from Colombia), she divided the group into three species. It is true that genitalia differences are used to support separation at the specific level, but the possibility that geographical variations of genitalia exist within a single species cannot be excluded. Therefore, in the case of the Eryphanis zolvizora group, we think that plausible taxonomic decisions cannot be taken without knowing the characteristics of populations distributed throughout its range from Bolivia to Venezuela, and especially Peru.

Fruhstorfer (1912) considered Eryphanis zolvizora as a very rare species, reflected in the small numbers of specimens housed in most public and private collections. Here, we aim to provide a comparative study

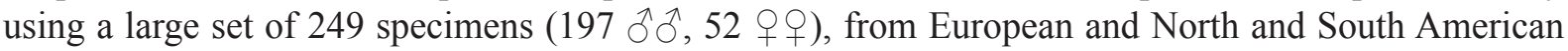
public and private collections. Firstly, we present a geographical survey of the Eryphanis zolvizora group. It exists throughout the Central and Northern Andes, from Bolivia to Venezuela, a country where the existence of zolvizora-like populations had not been reported before. We also confirm the existence of populations in western Ecuador. Data on altitudinal distribution are discussed. We dissected many specimens to compare genitalia, and we specify differences between populations from different areas. Moreover, we discovered individual variations of some genitalia characters. Several new taxa are recognised. We discuss two competing taxonomic arrangements - several species vs. one polytypic species - which are possible in the present state of knowledge.

\section{Material and methods}

A historical survey of the discovery of the Eryphanis zolvizora group is provided in Appendix 1 and a detailed list of the specimens studied here is provided in Appendix 2. For the purpose of this study, we divided Peru into a southern part, including Puno, Madre de Dios and Cusco Departments, a central part, including Junín and Pasco Departments, and a northern part, including Huánuco, La Libertad, Cajamarca, San Martín and Amazonas Departments. Private and public collections visited are listed and their respective acronyms used throughout the text are indicated below:

$\begin{array}{lll}\text { AMNH } & = & \text { American Museum of Natural History, New York, USA } \\ \text { AN } & = & \text { Andrew Neild collection, London, UK } \\ \text { ANSP } & = & \text { Academy of Natural Sciences, Philadelphia, USA } \\ \text { BMNH } & = & \text { Natural History Museum, London, UK } \\ \text { CAS } & = & \text { California Academy of Sciences, San Francisco, USA } \\ \text { CBF } & = & \text { Colección Boliviana de Fauna, La Paz, Bolivia } \\ \text { FLMNH } & = & \text { McGuire Center for Lepidoptera and Biodiversity, Florida Museum of } \\ & & \text { Natural History, University of Florida, Gainesville, USA } \\ \text { FP } & = & \text { Francisco Piñas collection, Quito, Ecuador } \\ \text { HAGAM } & = & \text { Herbert Art Gallery \& Museum, Coventry, UK } \\ \text { IAvH } & = & \text { Instituto Alexander von Humboldt, Bogotá, Colombia } \\ \text { ICNUN } & = & \text { Instituto de Ciencias Naturales, Bogotá, Colombia } \\ \text { IRSN } & = & \text { Institut Royal des Sciences Naturelles, Brussels, Belgium } \\ \text { JCS } & = & \text { Juan Carlos De Sousa Coelho collection, Funchal, Madeira } \\ \text { JFLC } & = & \text { Jean-François Le Crom collection, Bogotá, Colombia } \\ \text { JS } & = & \text { Julián Salazar collection, Manizales, Colombia } \\ \text { LACM } & = & \text { Natural History Museum of Los Angeles County, USA } \\ \text { MCC } & = & \text { Mauro and Clara Costa collection, Caracas, Venezuela }\end{array}$




\begin{tabular}{|c|c|c|}
\hline MECN & $=$ & Museo Ecuatoriano de Ciencias Naturales, Quito, Ecuador \\
\hline MHNC & $=$ & $\begin{array}{l}\text { Museo de Historia Natural Alcide d’Orbigny, Entomología, Cochabamba, } \\
\text { Bolivia }\end{array}$ \\
\hline MHNNKM & $=$ & Museo de Historia Natural Noel Kempff Mercado, Santa Cruz, Bolivia \\
\hline MIZA & $=$ & Museo del Instituto de Zoología Agrícola, Maracay, Venezuela \\
\hline MJP & $=$ & $\begin{array}{l}\text { Museo de Historia Natural 'Javier Prado', Universidad Nacional Mayor de } \\
\text { San Marcos, Lima, Peru }\end{array}$ \\
\hline MNHN & $=$ & $\begin{array}{l}\text { Muséum National d'Histoire Naturelle, Paris, France (CG: collection générale; } \\
\text { PBB: collection Patrick Blandin (Brassolini); PBGL: specimens collected } \\
\text { during Patrick Blandin and Gilbert Lachaume studies in northern Peru) }\end{array}$ \\
\hline MPM & $=$ & Milwaukee Public Museum, Wisconsin, USA (pictures provided by C. Penz) \\
\hline MZUJ & $=$ & Zoological Museum of the Jagiellonian University, Krakow, Poland \\
\hline NNM & $=$ & Nationaal Natuurhistorisch Museum, Leiden, The Netherlands \\
\hline PW & $=$ & Peter Wilson collection, Cornwall, UK \\
\hline $\mathrm{R}$ & $=$ & Romero Family collection, Maracay, Venezuela \\
\hline RAMM & $=$ & Royal Albert Memorial Museum, Exeter, UK \\
\hline SA & $=$ & Stéphane Attal collection, Paris, France \\
\hline UFPC & $=$ & Universidade Federal do Paraná, Curitiba, Paraná, Brazil \\
\hline UMO & $=$ & Oxford University Museum of Natural History, Oxford, UK \\
\hline USNM & $=$ & $\begin{array}{l}\text { National Museum of Natural History, Smithsonian Institution, Washington DC, } \\
\text { USA }\end{array}$ \\
\hline ZMHB & $=$ & Zoologisches Museum der Humboldt-Universität, Berlin, Germany \\
\hline ZMUA & $=$ & Zoologisch Museum, Amsterdam, The Netherlands \\
\hline
\end{tabular}

Other abbreviations used throughout the text:

$\begin{array}{lll}\mathrm{D} & = & \text { dorsal, upperside } \\ \mathrm{DFW} & = & \text { dorsal, upperside forewing } \\ \mathrm{DHW} & = & \text { dorsal, upperside hindwing } \\ \text { FW } & = & \text { forewing } \\ \text { FWL } & = & \text { horewing length (measured from the base to the tip of the wing) } \\ \text { HT } & = & \text { hindwing } \\ \text { HW } & = & \text { length } \\ \text { L } & = & \text { lectotype } \\ \text { LT } & = & \text { paralectotype } \\ \text { PLT } & = & \text { syntype } \\ \text { PT } & = & \text { ventral, underside } \\ \text { ST } & = & \text { ventral, underside forewing } \\ \text { V } & = & \text { ventral, underside hindwing }\end{array}$

When necessary, authors of this paper are indicated by corresponding initials: PB (Patrick Blandin); RB (Roger Bristow); AN (Andrew Neild); JCSC (Juan Carlos De Sousa Coelho); YG (Yuvinka Gareca); BH (Blanca Huertas).

In addition to the characters which appeared important to Penz (2008), we have studied several additional characters, such as the colour of the androconial patch in the anal area of the hindwing, which varies between Eryphanis species and sometimes between subspecies (unpublished observations). We recognize the following characters which may have a diagnostic role (Figs 1,2): 
a) importance of projection of $\mathrm{Cu} 1$ on $\mathrm{HW}$, evaluated by the value in millimetres $(\mathrm{mm})$ of the index $\mathrm{P}$ $=\mathrm{LCu} 1-((\mathrm{LM} 3+\mathrm{LCu} 2) / 2)$, where $\mathrm{LM} 3, \mathrm{LCu} 1$ and $\mathrm{LCu} 2$ are the length between the tips of the veins $\mathrm{M} 3, \mathrm{Cu} 1$ and $\mathrm{Cu} 2$ and the point of origin of $\mathrm{Cu} 2$ at the cubital cell vein (Fig. 1a);

b) presence (vs. absence or incompleteness) on DFW of an orange mark between veins R5-M1, extending the submarginal band towards the anterior wing margin, thus forming Penz's "proximal branch" of the submarginal band (Fig. 1b);

c) size and shape of the orange marks forming the submarginal band on DFW (Fig. 1c);

d) development of violet-blue iridescence on the dorsal surface (Fig. 1d);

e) length and colour of the male androconial patch in the anal area of DHW (Fig. 1e);

f) ground colour of the ventral surface, and colour of the median area, between the proximal and distal white stripes (Fig. 2f) (we compared recently collected specimens to old specimens collected more

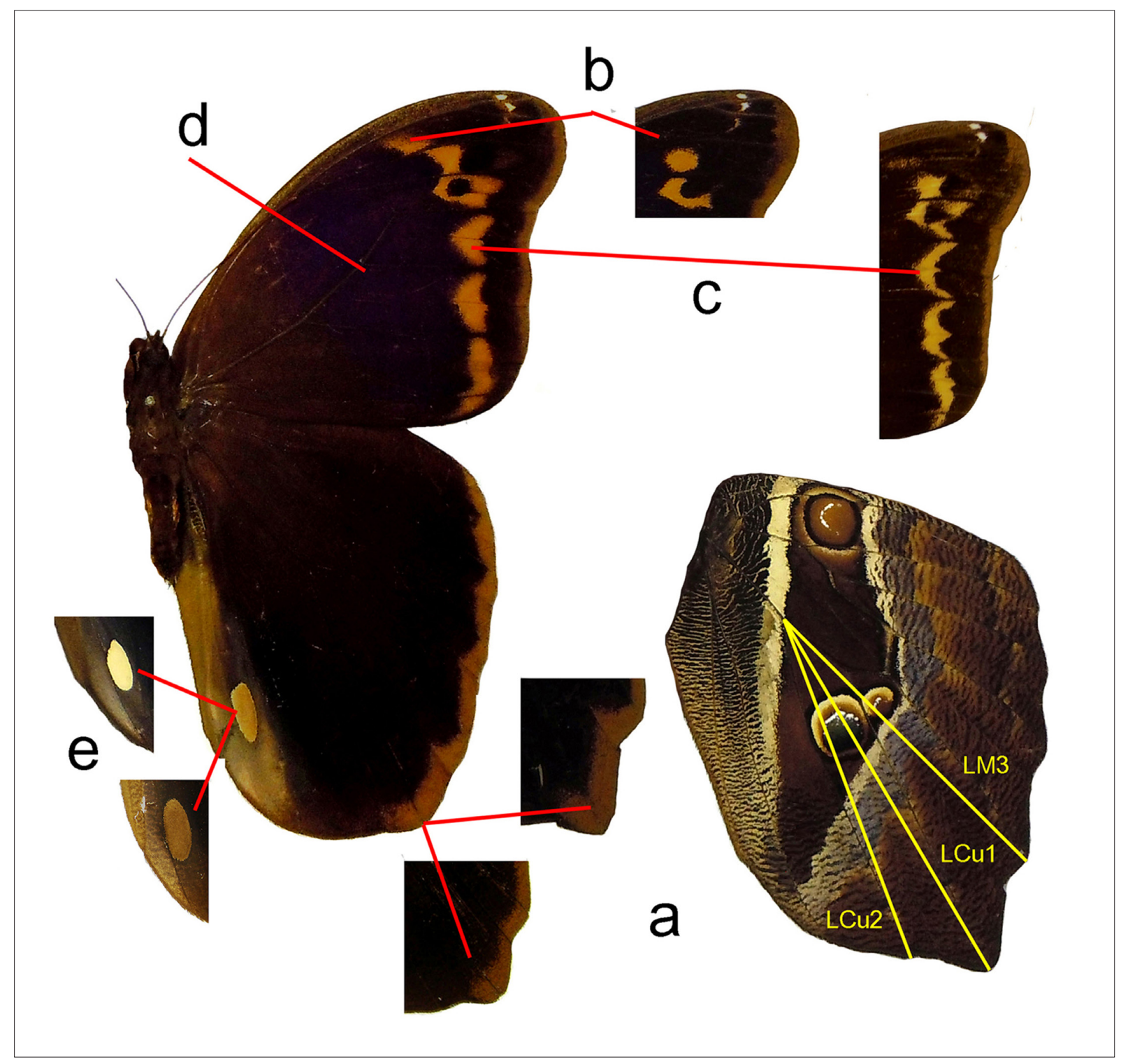

Fig. 1. Characters studied on the habitus (recto) and their major variations. a. HW projection, estimated by $\mathrm{P}=\mathrm{LCu} 1-((\mathrm{LM} 3+\mathrm{LCu} 2) / 2)$ in milimetres $)$. b. Orange mark between veins R5-M1. c. Size and shape of the orange marks. d. Violet-blue iridescence. e. Male androconial patch. 
than a century ago, and we did not observe significant differences between ventral surfaces, but we observed the opposite on dorsal surfaces, which are paler in old specimens);

g) shape and size of the isolated white spot situated approximately at the middle of the VFW cell, between $\mathrm{Cu} 1$ and $\mathrm{Cu} 2$ (Fig. 2g);

h) presence and size of a white spot at the angle formed by the cubital vein of the VFW cell and $\mathrm{Cu} 2$ (Fig. 2h);

i) presence (vs. absence or incompleteness) on the VFW of a connection ('bridge') between the basal and median white stripes in cell Cu2-2A (Fig. 2i);

j) length on the VHW of posterior extension of the proximal and distal white stripes (Fig. 2j);

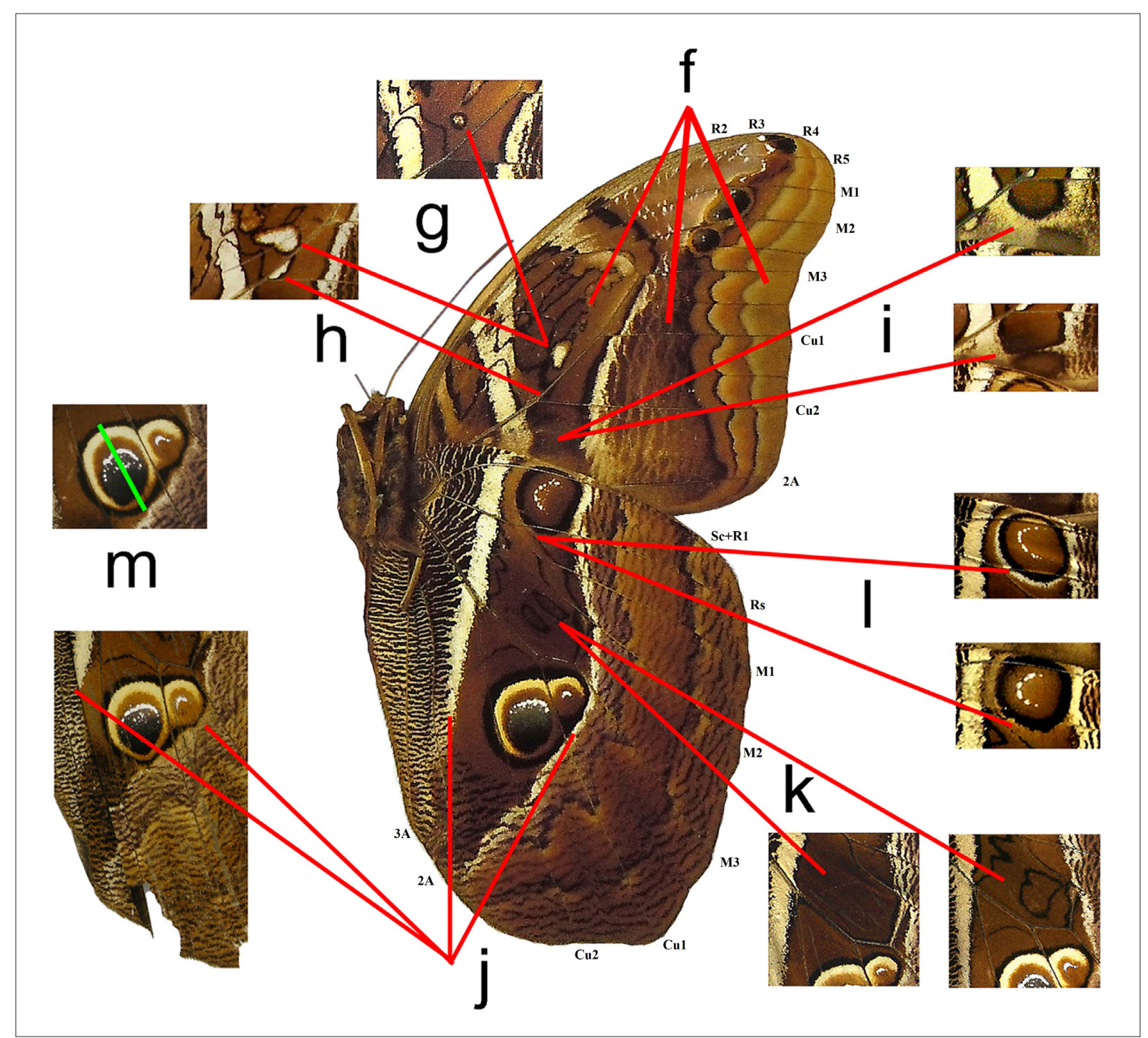

Fig. 2. Characters studied on the habitus (verso), and their major variations. f. Ground colour of the ventral surface and of the median area. g. Isolated white spot on FW cell. $\mathbf{h}$. White spot at the angle formed by the cubital vein of the FW cell and Cu2. i. 'Bridge' between white stripes in FW cell Cu2-2A. j. Length on HW of posterior extension of the white stripes. k. Black designs in the HW cell, and black curved line anterior to the $\mathrm{Cu} 1-\mathrm{Cu} 2$ ocellus. I. Ring around the HW costal ocellus. m. Widest diameter $\Phi$ of the HW Cu1-Cu2 ocellus. 
k) on the VHW, prominence (vs. absence or incompleteness) of the black designs in the cell, and of a black, curved line between veins $\mathrm{Cu} 1$ and $\mathrm{Cu} 2$, anterior to the $\mathrm{Cu} 1-\mathrm{Cu} 2$ ocellus (Fig. 2k);

1) presence (vs. absence or incompleteness) of a white ring around the VHW costal ocellus; completeness or incompleteness of the inner black ring (Fig. 21);

m) size of the VHW Cu1-Cu2 ocellus, evaluated by its widest diameter $\Phi$ (parallel to $\mathrm{Cu} 1$ ), measuring from the outer margin of the prominent dark brown ring (Fig. $2 \mathrm{~m}$ ).

Most of the studied specimens were photographed. Photographs were taken with different cameras and in different light conditions. Despite our best efforts to correct them, there are still disparities in colour
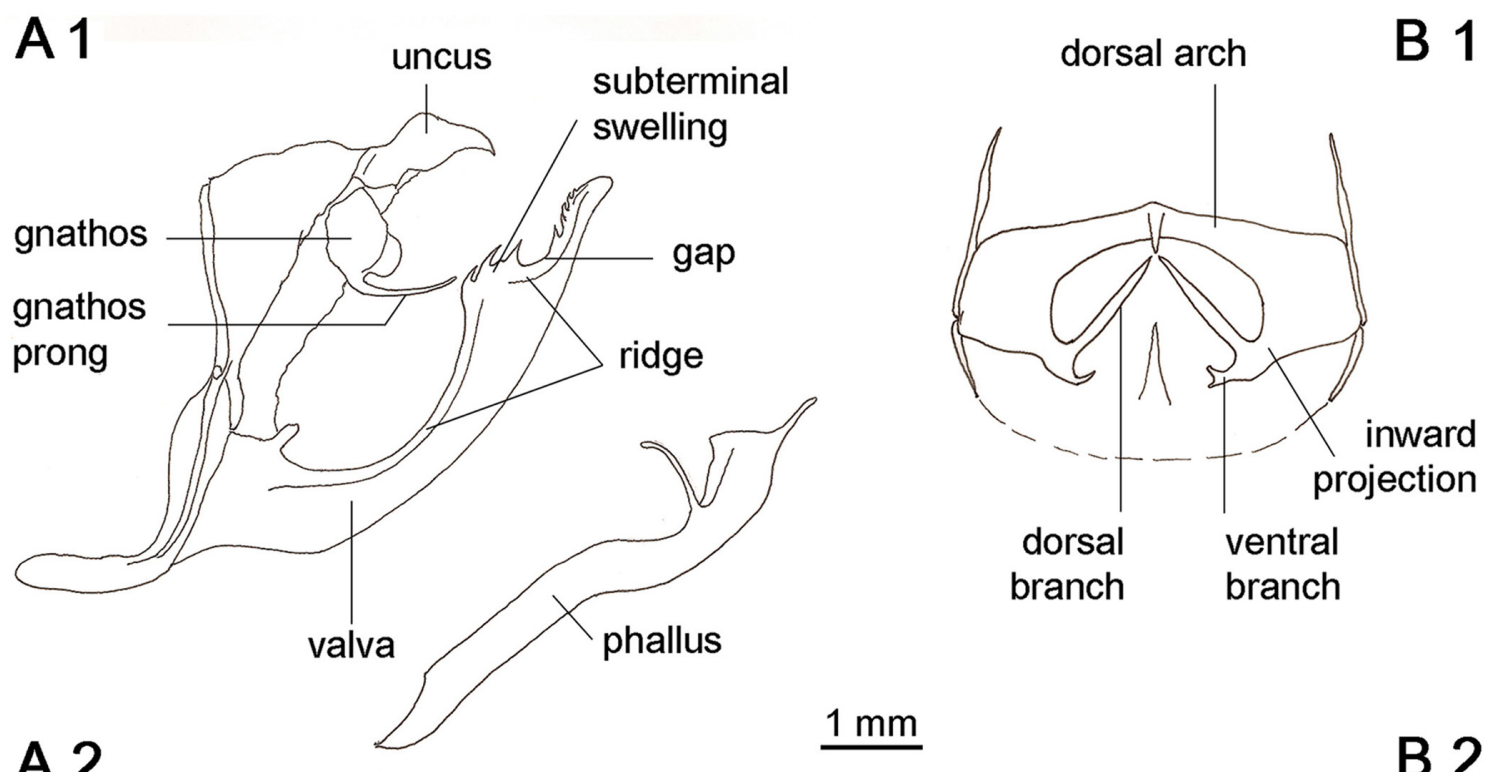

A 2

$\underline{1 \mathrm{~mm}}$
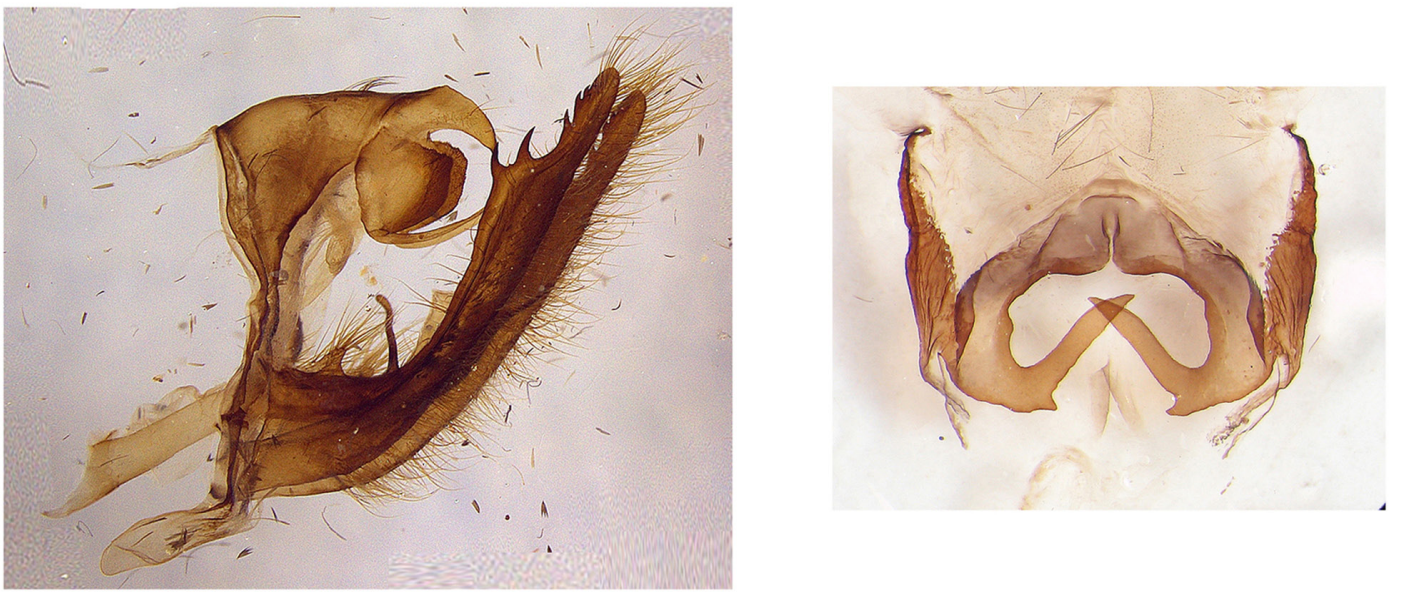

Fig. 3. Characters studied on genitalia. A1. Male from Bolivia (Eryphanis zolvizora zolvizora (Hewitson, 1877); MNHN, PBB 2286). A2. Male from Central Peru (La Suiza, Pasco; UFPC; PT of Eryphanis zolvizora chachapoya ssp. nov.; picture by M. M. Casagrande). B1. Female from Bolivia (Eryphanis zolvizora zolvizora (Hewitson, 1877); MNHN, CG). B2. Female from Venezuela (Rancho Grande, Aragua; PT of Eryphanis zolvizora isabelae ssp. nov.; 118-JCSC; picture by J.-C. de Sousa). 


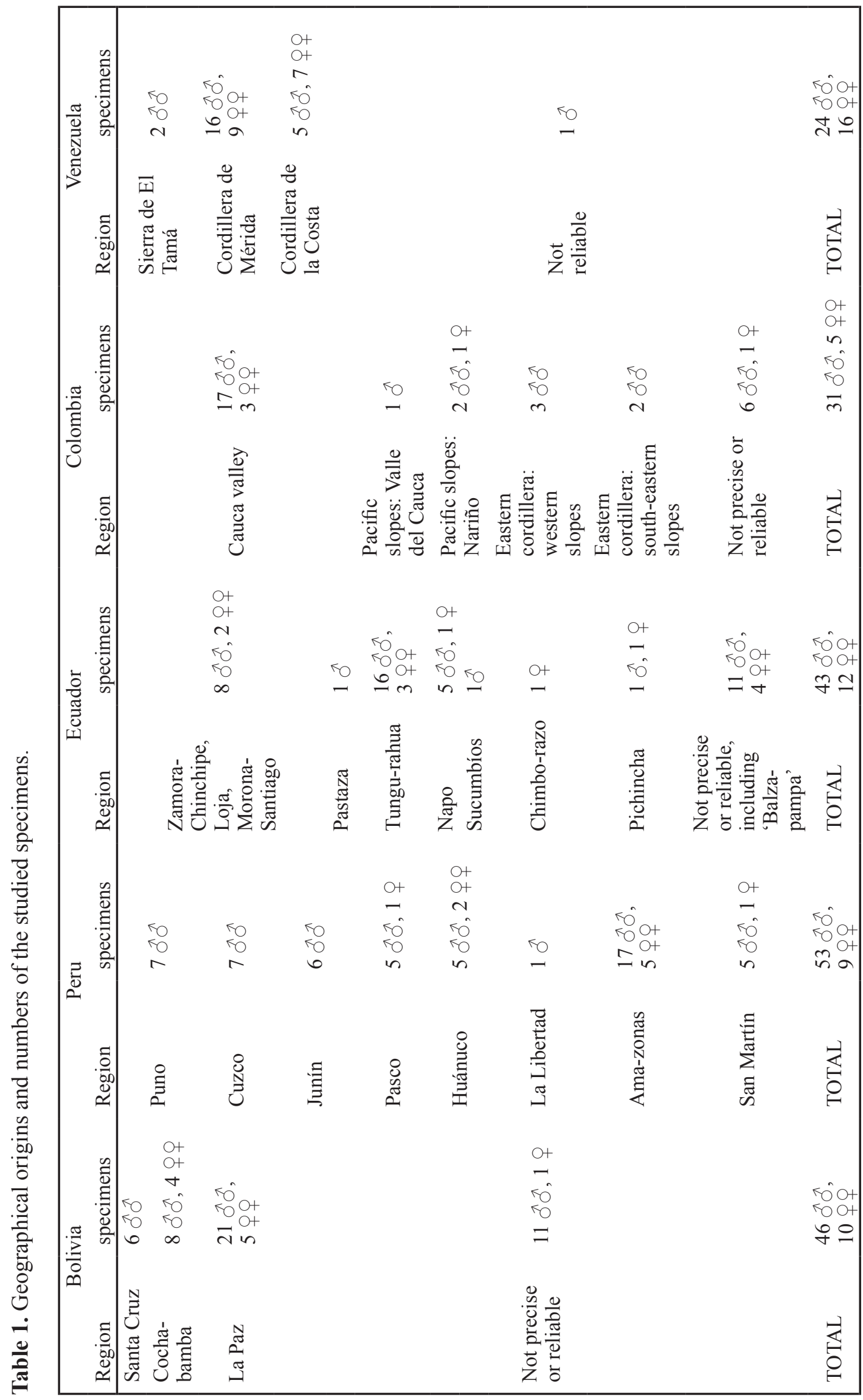


Table 2. Altitudinal range of the Eryphanis zolvizora group.

\begin{tabular}{|c|c|c|l|}
\hline Country & $\begin{array}{c}\text { Lower reliable } \\
\text { altitudes }\end{array}$ & $\begin{array}{c}\text { Higher reliable } \\
\text { altitudes }\end{array}$ & More or less doubtful low altitudes \\
\hline Bolivia & $1000 \mathrm{~m}$ & $2600 \mathrm{~m}$ & Buena Vista; Chapare <400 m \\
\hline Peru & $1300-1400 \mathrm{~m}$ & $2800 \mathrm{~m}$ & Chirimayo, "1000 ft" \\
\hline Ecuador & $1500 \mathrm{~m}$ & $2163 \mathrm{~m}$ & $\begin{array}{l}\text { R. Arajuno, 700 m; Napo, } 465 \mathrm{~m} \\
\text { Santo Domingo (Pichincha), 200 m }\end{array}$ \\
\hline Colombia & $900 \mathrm{~m}$ & $2500 \mathrm{~m}$ & $\begin{array}{l}\text { Buenaventura-Queremal, 200 m } \\
\text { Puerto Nariño, 150 m }\end{array}$ \\
\hline Venezuela & $1150 \mathrm{~m}$ & $2100 \mathrm{~m}$ & \\
\hline
\end{tabular}

balance, contrast, and saturation, and relatively subtle colour differences are not always obvious on the photographs of variable quality that we have reproduced on our composite figures.

Measurements of FWL, length of the androconial patch, LM3, LCu1, LCu2 and $\Phi$ were taken directly from specimens, or from scaled pictures, the precision being $\pm 0.5 \mathrm{~mm}$. Where necessary, we indicate the number (n) of measurements, and minimum ( $\min )$ and maximum (max) values. On some damaged specimens, LCul could not be measured and the P index could not be calculated. The specimens on which measurements were made are indicated in Appendix 2.

Genitalia were prepared using a $10 \%$ solution of $\mathrm{KOH}$ and stored in a glycerol/ $70 \%$ ethanol solution (3:1). Structures were observed using an optical stereo microscope with light and white field. Descriptive terms (Fig. 3) are those used by Penz (2008). The specimens which were dissected are indicated in Appendix 2.

\section{Results}

\section{Geographic distribution and altitudinal range}

In a synthesis of brassoline biogeography, Blandin (1977) included E. zolvizora in the group of species associated with Andean montane forest and provided a map showing its distribution from Bolivia to Colombia, indicating a few areas along the Andes. Even today, tens if not hundreds of kilometres separate "neighbouring" localities. However, thanks to our survey of more than 150 specimens with correct data (Table 1), a regional pattern becomes apparent. The zolvizora group is distributed in the whole Tropical Andes Hotspot, as defined in Mittermeier et al. (2004). In the Central Andes, it exists along the eastern Andean slopes from Bolivia (Santa Cruz Department) to the Peruvian north-eastern cordilleras (San Martín and Amazonas Departments). In the Northern Andes, it extends along the Ecuadorian and Colombian eastern cordilleras, and then along the Cordillera de Mérida and the Cordillera de la Costa in Venezuela. In western Ecuador, its existence is confirmed, and it extends northwards along the Pacific side of the Colombian western cordillera. The E. zolvizora group is also represented in Colombia on the oriental slopes of the western cordillera, in the central cordillera (at least on its western slopes), and on both sides of the eastern cordillera.

Most reliable altitudinal data range from 900 to $2800 \mathrm{~m}$ (Table 2; see Appendix 2 for detailed data). Fassl (1915a) indicated E. opimus on both sides of the western Colombian cordillera at heights between 2000 and $2500 \mathrm{~m}$. In Venezuela, most specimens were taken between about 1150 and $1500 \mathrm{~m}$ elevation, although this is most likely a reflection of the lack of access to higher elevations at each site rather than an indication of the true upper limit of the species, as a few specimens have been collected between 1900 
to $2100 \mathrm{~m}$. These altitudes correspond to cloud forests in the broadest sense. These ecosystems exist, in large mountain ranges as the Andes, between 1500 and $3500 \mathrm{~m}$ (Brown \& Kappelle 2001). According to some authors, cloud forests can be observed as low as $1300 \mathrm{~m}$, for example on eastern Peruvian slopes (Brack Egg \& Mendiola Vargas 2004). These cloud forests are characterized by bamboos belonging to the genus Chusquea. Harold Greeney reared E. greeneyi on Chusquea scandens at the Yanayacu Biological Station, c. 2100 m, in eastern Ecuador (Penz 2008). It is likely that the distribution of the E. zolvizora group depends on the altitudinal range and geographical extent of cloud forest Chusquea species.

Given this information, lower elevations are most likely the result of mislabelling. From Bolivia, two specimens in the FLMNH collected in 1925 and 1994 are labelled 'Buenavista', a lowland locality (under $400 \mathrm{~m}$ ) in Santa Cruz Department. We have confirmed that zolvizora populations do exist in the Andean slopes of Santa Cruz Department, but not in the vicinity of Buena Vista. Perhaps there was a confusion with Bellavista, where E. zolvizora has been collected recently. There is also one male in MNHN (PBB 260), probably mislabelled, from "Chapare $300 \mathrm{~m}$ ". A Peruvian specimen (BMNH) is labelled "Chirimayo, $1000 \mathrm{ft}$, Ockenden, July 1901"; it is likely that there is a typographic error, as Ockenden's data are generally reliable. From eastern Ecuador, some specimens with altitudes as low as 700 m (a specimen labelled "Río Arajuno", Napo Province, Ecuador, in MNHN) and $465 \mathrm{~m}$ (a specimen labelled [Puerto] Napo, Napo Province, Ecuador; PW) almost certainly are mislabelled. It should be noted that in Ecuador (and other countries), data from commercial collectors are often unreliable. The female labelled from Santo Domingo, $200 \mathrm{~m}$, in Pichincha Province, is supposed to have been collected at a higher altitude along the road to Quito. A Colombian specimen (IAvH), labelled "Buenaventura-Queremal, 200 m, Valle de Cauca", was collected by Schmidt-Mumm, who often made errors, indicating with apparent precision (altitude, longitude, latitude) incorrect localities (J.-F. Le Crom, pers. comm.). We consider that this specimen was probably collected in the mountains, along the road from Buenaventura to Cali. There is also a male labelled from Puerto Nariño, in the Amazonian lowlands, which is certainly mislabelled.

However, one cannot exclude the possibility that cloud forests may exist at altitudes lower than $1000 \mathrm{~m}$, in orographic situations favouring cold and hyper-humid local conditions. For example, in Venezuela, along the Río Frío in the eastern El Tamá range, one of the authors (AN) regularly but infrequently encountered and received reports of lower montane forest species as low as $650 \mathrm{~m}$. This seems to be related to local topography, with extremely steep slopes and very humid and luxuriant valleys. The observations above allow us to stress the fact that the Eryphanis zolvizora group exhibits significant variation in altitudinal range.

\section{Morphological characters}

Male habitus (Figs 4A-F, 5A-F, 6A-D)

FWL generally varies between 55 and $67 \mathrm{~mm}$ in all populations. Only one dwarf specimen was encountered, from Barinitas (Venezuela), with a FWL of $52 \mathrm{~mm}$; it has not been included in the measurement statistics.

The hindwing projection is reduced in Bolivian specimens (average $\mathrm{P}=3.3$, cf. Table 3 ) and medium (average $\mathrm{P}=4.4$ ) in the southern and central Peruvian specimens. The northern Peruvian specimens and 4 specimens from central Peru (San Francisco, "Río Perené", La Suiza, Huancabamba) have a strong projection, as well as northern Peruvian and eastern Ecuadorian specimens (average $\mathrm{P}=5.6$ and 5.5, respectively). Colombian specimens from the valley of the Río Cauca and Venezuelan specimens have reduced or medium projections, the average values of P ranging from 3.6 to $4.3 \mathrm{~mm}$. In other regions of the Northern Andes (western Ecuador and Nariño Department on one hand, north of the Colombian Cordillera Oriental on the other), individual values of P range from 4.0 to $5.5 \mathrm{~mm}$. 


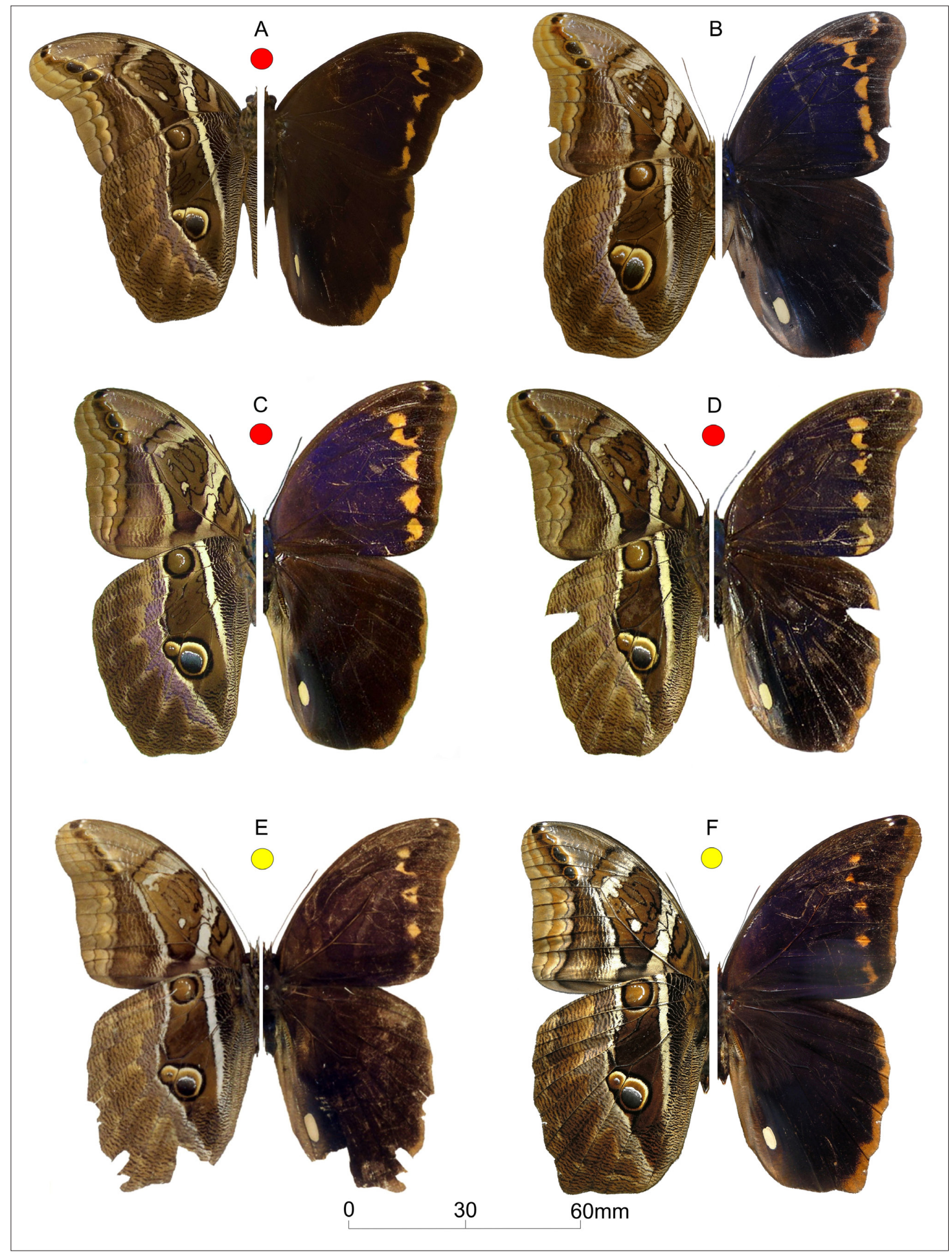

Fig. 4. Habitus of males. Red spot: holotype (HT) or lectotype (LT). Yellow spot: syntype (ST) or paratype (PT). A. Eryphanis zolvizora zolvizora (Hewitson, 1877), LT (Bolivia; BMNH). B. The southernmost known specimen of E. z. zolvizora (Manchones, Santa Cruz, Bolivia; MHNC). C. Eryphanis zolvizora inca ssp. nov., HT (Aguas Calientes, Cuzco, Peru; MJP). D. Eryphanis zolvizora chachapoya ssp. nov., HT (Huamanpata, Amazonas, Peru; MJP). E. Eryphanis z. chachapoya ssp. nov., ST of Eryphanis opimus Staudinger, 1887, from Chanchamayo, Junín, Peru (BMNH). F. PT of E. z. chachapoya ssp. nov. with small spots (Alto Nieva, Amazonas, Peru; MNHN, PBGL 706). 


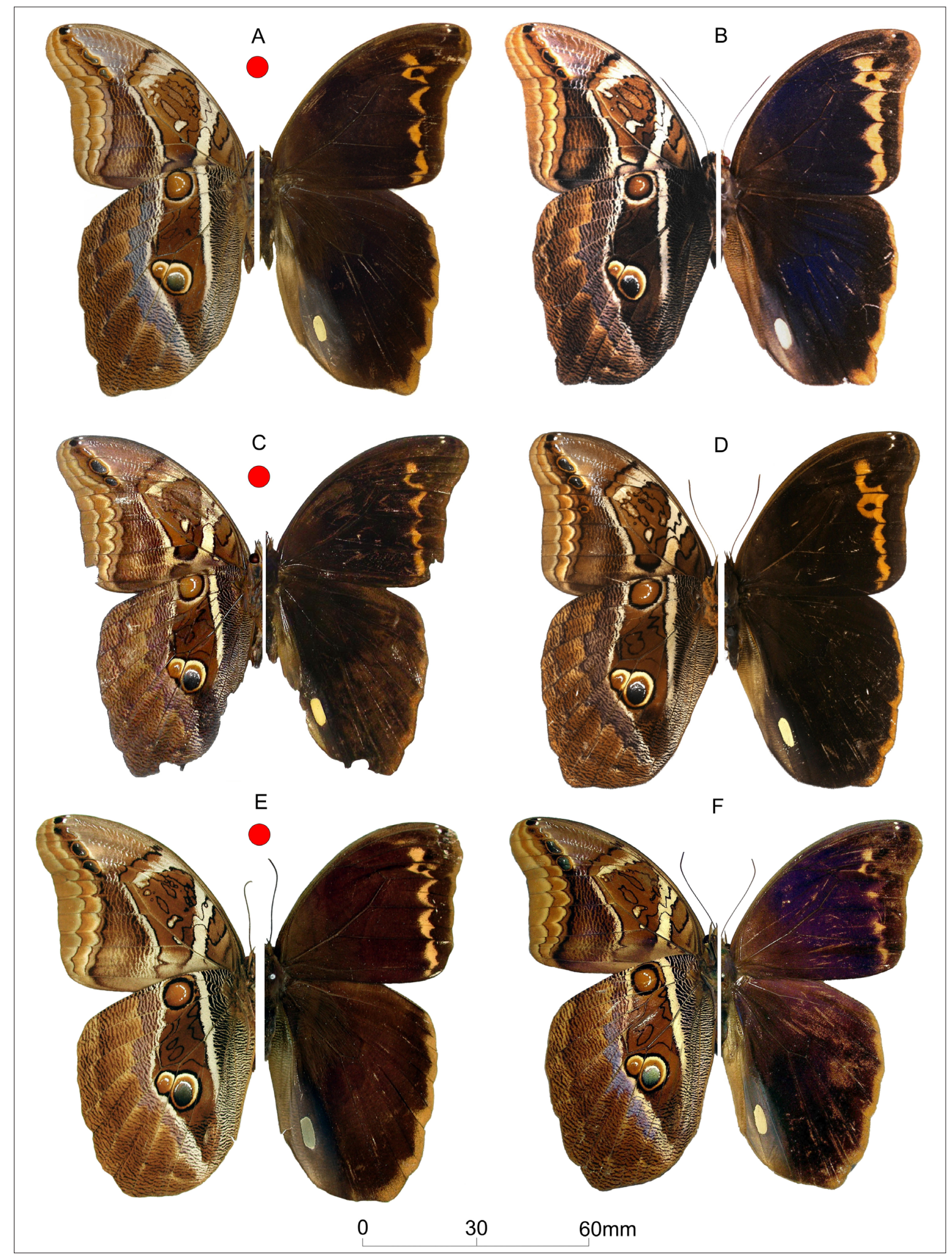

Fig. 5. Habitus of males. Red spot: holotype (HT) or lectotype (LT). A. Eryphanis zolvizora greeneyi Penz \& DeVries, 2008, stat. rev., HT (Yanayacu, Napo, Ecuador; BMNH). B. E. z. greeneyi, specimen with increased forewing spots (Baeza, Napo, Ecuador, Pinas). C. Eryphanis zolvizora casagrande ssp. nov., HT (Altaquer, Nariño, Colombia; ICNUN). D. E. z. casagrande from Western Ecuador (Las Gralarias, Pichincha; FLMNH). E. Eryphanis zolvizora opimus (Staudinger, 1887), LT (Manizales, Colombia; ZMHB). F. E. z. opimus, specimen with reduced spots (Cauca, Colombia; MNHN, CG). 
The ground colour of the male dorsal surface is a dark brown (faded into a paler brown in old specimens). There is a violet-blue iridescence on the median part of the wings. This iridescence is very faint in Bolivian specimens, notably on the HW, and more pronounced in Venezuelan specimens, notably from the Cordillera de la Costa. Specimens from southern Peru have a more brilliant violet than Bolivian males, on both the FW and HW; however, there are individual variations. Specimens from northern Peru and eastern and western Ecuador are intermediate. In most Colombian specimens, the iridescence is notably pronounced, but generally less than in Venezuelan specimens.

On the DFW, orange marks form a submarginal band. Bolivian males have a supplementary orange mark in R5-M1 (sometimes not very pronounced) forming a proximal branch to this submarginal band. This mark appears, more or less faded, in a majority of specimens from southern Peru. It is more often absent in other populations, or very faint in some Colombian specimens. The other orange marks

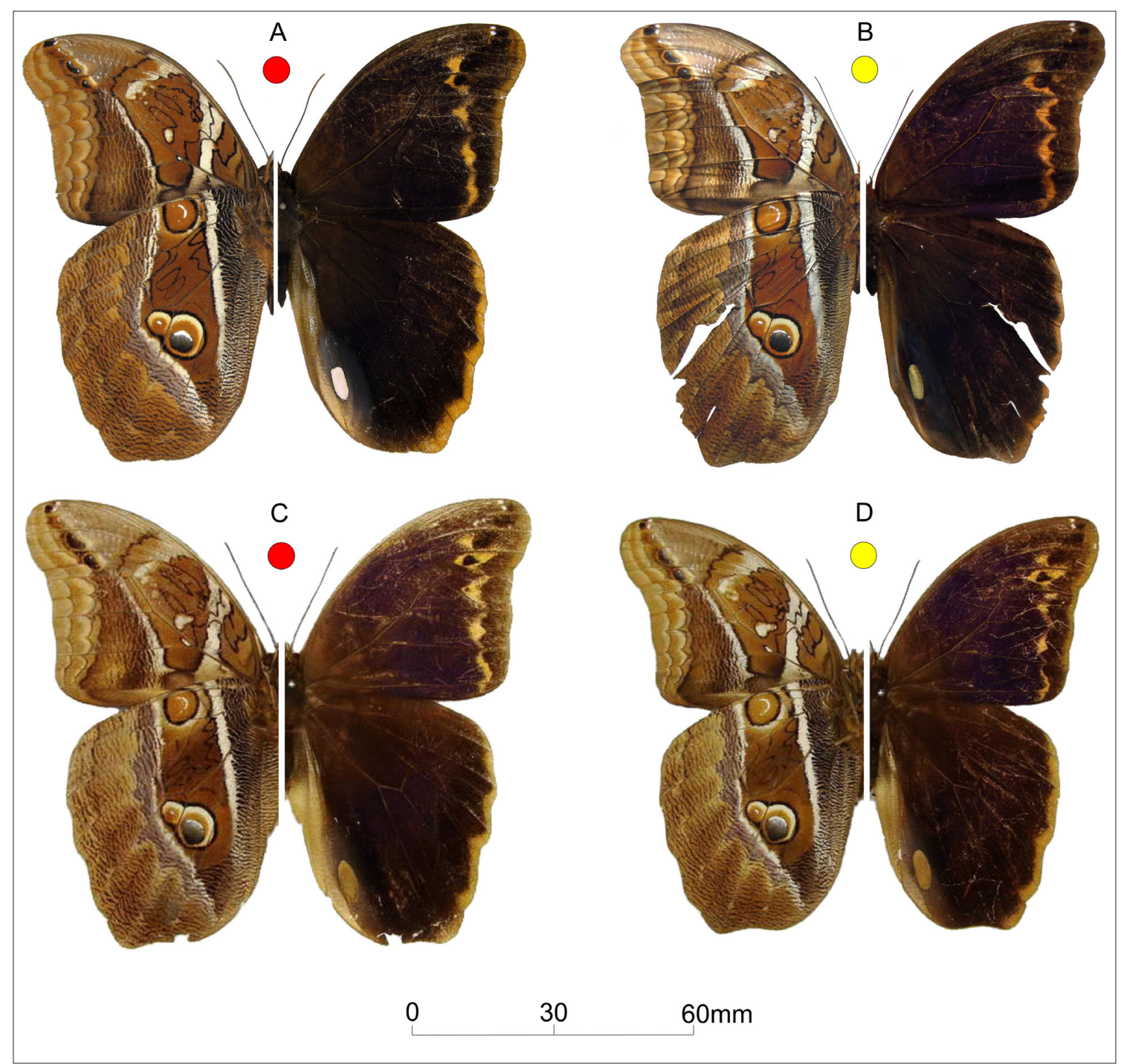

Fig. 6. Habitus of males. Red spot: holotype (HT). Yellow spot: paratype (PT). A. Eryphanis zolvizora reyi ssp. nov., HT (La Chimenea, Barinas, Venezuela; MIZA). B. E. z. reyi ssp. nov., PT (Charalá, Colombia; MNHN, PBB 2321). C. Eryphanis zolvizora isabelae ssp. nov., HT (Choroní, Aragua, Venezuela; R, to be donated to MIZA). D. E. z. isabelae ssp. nov., PT; specimen with reduced forewing spots (Choroní, Aragua, Venezuela; R). 
Table 3. Variation of the hindwing projection index $\mathrm{P}$ in males $(\mathrm{n}=$ number of individuals on which measurements have been made, directly or on scaled pictures).

\begin{tabular}{|l|c|c|c|c|}
\hline \multirow{2}{*}{ Country } & \multirow{2}{*}{$\mathrm{n}$} & \multicolumn{3}{c|}{$\mathrm{P}(\mathrm{mm})$} \\
\cline { 3 - 5 } & & Average value & Minimum value & Maximum value \\
\hline Bolivia & 14 & 3.3 & 2.0 & 4.5 \\
\hline $\begin{array}{l}\text { Southern Peru and 2 specimens from } \\
\text { central Peru }\end{array}$ & 14 & 4.4 & 3.7 & 5.8 \\
\hline $\begin{array}{l}\text { Northern Peru and 4 specimens from } \\
\text { central Peru }\end{array}$ & 27 & 5.6 & 4.8 & 6.5 \\
\hline Eastern Ecuador & 11 & 5.5 & 4.6 & 6.5 \\
\hline Pichincha, Western Ecuador & 1 & 4.4 & - & - \\
\hline Nariño, Western Colombia & 1 & 5.5 & - & - \\
\hline Cauca Valley, Colombia & 6 & 3.9 & 3.0 & 4.5 \\
\hline North of eastern cordillera, Colombia & 2 & 4.9 & 4.8 & 5.0 \\
\hline $\begin{array}{l}\text { El Tamá and Mérida ranges, } \\
\text { Venezuela }\end{array}$ & 15 & 3.6 & 2.5 & 4.5 \\
\hline Cordillera de la Costa, Venezuela & 4 & 4.3 & 3.5 & 5.5 \\
\hline
\end{tabular}

forming the submarginal band vary widely in size. In Bolivia and southern Peru, males have generally large marks; on veins $\mathrm{M} 3, \mathrm{Cu} 1$ and $\mathrm{Cu} 2$ they are clearly separated (often more widely in southern Peru). In northern Peru the marks can be very large, as in several specimens from Amazonas, but also small, as in several specimens from San Martín and Huánuco. The same variability exists in Ecuador, Colombia and Venezuela. We hypothesize that this variation is a matter of intra-population variation, as clearly illustrated by specimens from the Santo Domingo Valley (Barinas, Venezuela). In Colombian and Venezuelan specimens, where the marks are large, they are often crescent shaped, and they are barely separated by the veins, which remain brown-black.

The length of the androconial patch in the HW anal fold varies from 5.0 to $9.0 \mathrm{~mm}$ (Table 4). Considering the variation between specimens of the same geographical group, we cannot conclude that there is any geographical variation other than in the Venezuelan Cordillera de la Costa, where the androconial length is clearly longer. Moreover, in this population, the androconial patch is pale greyish-brown, while it is a bright creamy, pale citrus yellow in all other populations, except a few specimens that also exhibit a pale greyish-brown.

The ventral background colour is ochre-brown, with little geographical variation. In Bolivian and southern Peruvian specimens, the ochre-brown often shows a yellowish tinge on the distal part of the wings, notably on the FW margins. The median area, between the white stripes, presents a contrasting darker ochre-brown colour. In northern Peru a majority of specimens exhibits a darker pattern: the FW margins are less yellow, and the median area is generally a dark chocolate-brown. Eastern Ecuadorian specimens are often more yellowish than northern Peruvian ones. Colombian and Venezuelan specimens have a lighter, yellowish aspect; the median area is lighter than in specimens from other countries. However, these differences do not have a definite value: for example, in northern Peru and Ecuador 
Table 4. Variations of the length of the male HW androconial patch $(n=$ number of individuals on which measurements have been made, directly or on scaled pictures).

\begin{tabular}{|l|c|c|c|c|}
\hline \multirow{2}{*}{ Country } & \multirow{2}{*}{$\mathrm{n}$} & \multicolumn{2}{c|}{ Length of the androconial patch (mm) } \\
\cline { 3 - 5 } & & average & minimum & maximum \\
\hline Bolivia & 14 & 7.1 & 6.0 & 8.0 \\
\hline $\begin{array}{l}\text { Southern Peru and 2 specimens from } \\
\text { central Peru }\end{array}$ & 14 & 7.4 & 6.4 & 8.5 \\
\hline $\begin{array}{l}\text { Northern Peru and 4 specimens from } \\
\text { central Peru }\end{array}$ & 31 & 7.3 & 5.0 & 9.0 \\
\hline Eastern Ecuador & 12 & 6.8 & 5.8 & 8.0 \\
\hline Pichincha, Western Ecuador & 1 & 8.3 & - & - \\
\hline Nariño, Western Colombia & 1 & 7.5 & - & - \\
\hline Cauca Valley, Colombia & 6 & 8.1 & 7 & 9.0 \\
\hline North of eastern cordillera, Colombia & 2 & 7.6 & 6.6 & 8.5 \\
\hline $\begin{array}{l}\text { El Tamá and Mérida ranges, } \\
\text { Venezuela }\end{array}$ & 16 & 7.0 & 5.8 & 7.5 \\
\hline Cordillera de la Costa, Venezuela & 6 & 9.0 & 8.3 & 9.5 \\
\hline
\end{tabular}

Table 5. Variations of the larger diameter $(\Phi)$ of the $\mathrm{Cu} 1-\mathrm{Cu} 2$ ocellus on male ventral hindwing. $(\mathrm{n}=$ number of individuals on which measurements have been made, directly or on scaled pictures).

\begin{tabular}{|l|c|c|c|c|}
\hline \multirow{2}{*}{ Country } & \multirow{2}{*}{$\mathrm{n}$} & \multicolumn{3}{c|}{$\Phi(\mathrm{mm})$} \\
\cline { 3 - 5 } & & Average value & Minimum value & Maximum value \\
\hline Bolivia & 14 & 12.0 & 10.5 & 14.7 \\
\hline $\begin{array}{l}\text { Southern Peru and 2 specimens from } \\
\text { central Peru }\end{array}$ & 14 & 12.1 & 10.1 & 14.7 \\
\hline $\begin{array}{l}\text { Northern Peru and 4 specimens from } \\
\text { central Peru }\end{array}$ & 31 & 10.0 & 8.5 & 11.5 \\
\hline Eastern Ecuador & 12 & 9.5 & 8.0 & 10.8 \\
\hline Pichincha, Western Ecuador & 1 & 10.5 & - & - \\
\hline Nariño, Western Colombia & 1 & 10.1 & - & - \\
\hline Cauca valley, Colombia & 6 & 10.7 & 9.5 & 11.9 \\
\hline North of eastern cordillera, Colombia & 2 & 10.0 & 9.9 & 10.0 \\
\hline $\begin{array}{l}\text { El Tamá and Mérida ranges, } \\
\text { Venezuela }\end{array}$ & 15 & 9.5 & 7.0 & 11.0 \\
\hline Cordillera de la Costa, Venezuela & 5 & 8.7 & 7.0 & 10.5 \\
\hline
\end{tabular}


as well, there are some specimens where the median area is not a dark chocolate-brown, but a lighter tobacco ochre-brown, as in southern Peru on the one hand, and as in Colombia on the other.

Both the VFW and VHW are crossed by two conspicuous white stripes. On the VFW, they are clearly separated in the cell Cu2-2A in Bolivian and southern Peruvian specimens, the inner margin of the distal stripe just forming a small tooth. In northern Peruvian and eastern Ecuadorian specimens, this tooth is often more developed, forming a dark projection which can connect with the outside black margin of the proximal stripe; exceptionally, this black connection is more or less filled with white scales. In specimens from western Ecuador and Nariño in south-western Colombia, the connection is complete, forming a white bridge with black margins. On the contrary, Colombian specimens from the Cauca Valley have just a short tooth, as in Bolivian males. In males from the north of the eastern Colombian cordillera and from Venezuela, the tooth is elongated and more often reaches the proximal stripe. On the VHW, the white stripes generally extend far posterior to the $\mathrm{Cu} 1-\mathrm{Cu} 2$ ocellus, especially the distal stripe. However, in the Nariño males the two stripes are shorter, reaching no more than the anterior edge of the ocelli.

Within the VFW cell, there is an isolated white patch next to the base of Cu1-Cu2. In specimens from the Cordillera de la Costa (northern Venezuela), this patch is generally much larger than in any other population, and roughly triangular or in the form of an inverted heart. At the angle formed by the cubital vein of the cell and $\mathrm{Cu} 2$, there is in the population of the Cordillera de la Costa an elongated white spot, which is always much smaller or even absent in all other populations.

In Bolivia and southern Peru, the VHW costal ocellus is circled by a brown, incomplete ring, a little paler than the median area. In northern Peru, this ring is lighter, and more or less covered by white scales, thus contrasting more strongly with the dark-brown median area. This is also the case in eastern Ecuadorian specimens, where the ring is often almost completely covered with bright white scales. In the only western Ecuadorian male that we have studied, the costal ocellus is circled by an almost complete white ring. It is the same in males from south-western Colombia (Nariño). In Colombian specimens from Cauca Valley, the ring is generally a poorly contrasting pale brown, with sometimes a few whitish scales. On the contrary, specimens from the eastern cordillera and from Venezuela (Cordillera de Mérida and Cordillera de la Costa) have whitish scales more developed. In all populations, there is an inner black circle, which is generally complete, notably in specimens from the Cauca Valley, but which is interrupted along the costa in specimens from the Cordillera de Mérida.

The size of the VHW Cu1-Cu2 ocellus is variable in all populations. However, it is clearly larger in Bolivian and southern Peruvian specimens. It is notably smaller in northern Peru and the Northern Andes, having the smallest values in northern Venezuela (Table 5).

The dark brown lines in the VHW cell, and the dark brown curved line above the Cu1-Cu2 ocellus, are well developed in Bolivian specimens. This is also the case for southern Peruvian specimens, but the dark brown curved line is sometimes faded, or even absent. In northern Peruvian specimens, all these lines are strongly faded, if not completely absent. They are not very well developed in eastern Ecuadorian specimens, being sometimes as faded as in northern Peru. On the contrary, they are well developed in western Ecuadorian, Colombian and Venezuelan specimens.

Female habitus (Figs 7A-F, 8A-B)

FWL generally varies between 61 and $68 \mathrm{~mm}$ in all populations. The general colour on both dorsal and ventral surfaces is lighter than in males, and there is usually an intense, median, violet-blue sheen to both FW and HW. Bolivian specimens have a fainter iridescence than all other females. On the contrary, in the northern Venezuelan populations, the dorsal colour is lighter, and more bluish, than in other populations. Other characters vary between populations as in males. In the females from Nariño (south- 


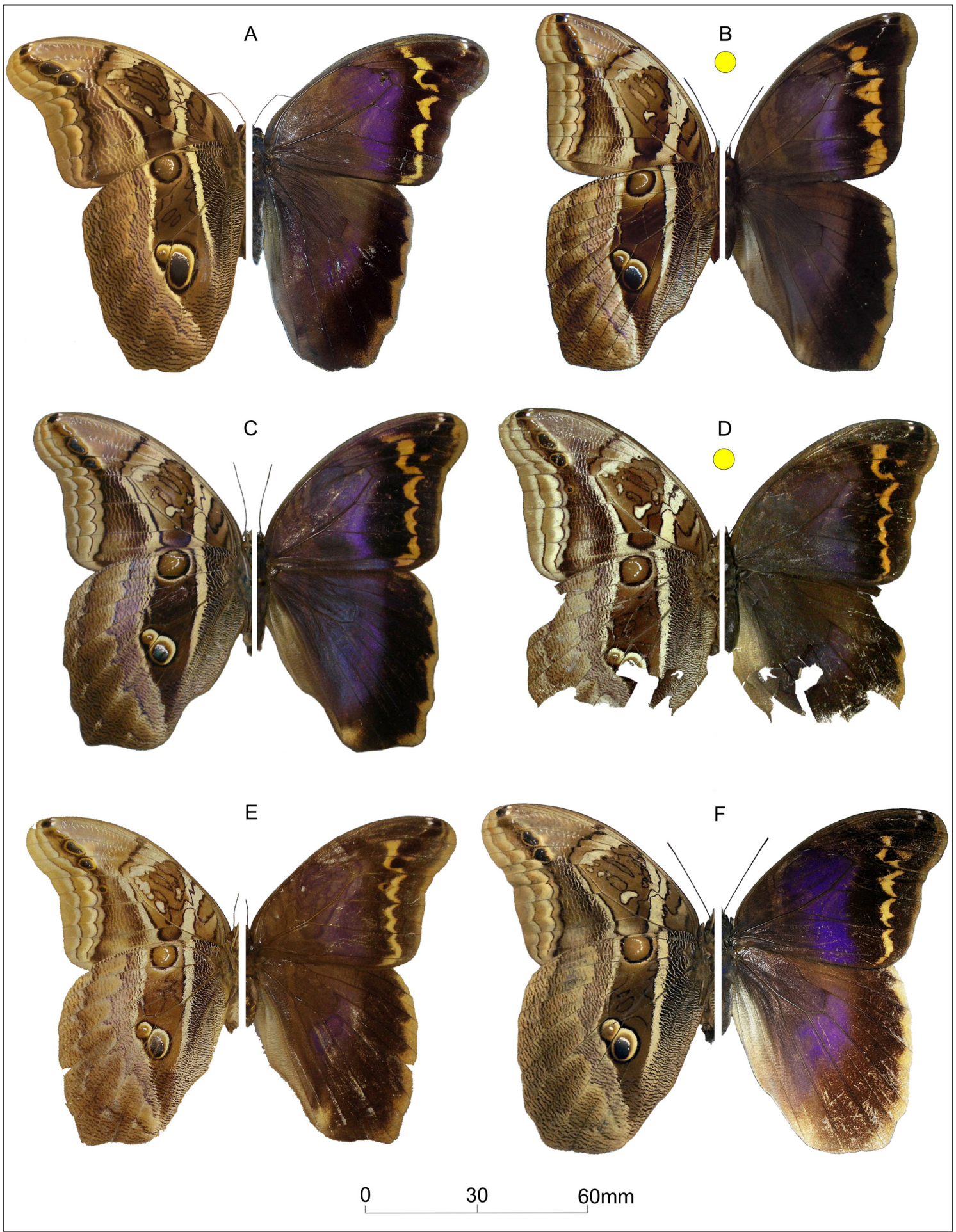

Fig. 7. Habitus of females. Yellow spot: paratype (PT). A. Eryphanis zolvizora zolvizora (Hewitson, 1877) (San Jacinto, Bolivia; BMNH). B. Eryphanis zolvizora chachapoya ssp. nov., PT (San José de Molinopampa, Amazonas, Peru; MNHN, PBGL 198). C. Eryphanis zolvizora greeneyi Penz \& DeVries, 2008, stat. rev. (Ecuador; JFLC). D. Eryphanis zolvizora casagrande ssp. nov., PT (La Planada, Nariño, Colombia; IAvH). E. E. z. casagrande ssp. nov. (Huigra, Chimborazo, Ecuador; ANSP). F. Eryphanis zolvizora opimus (Staudinger, 1887) (Río Agua (presumably Río Aguacatal), Valle del Cauca, Colombia; $\mathrm{BMNH})$. 


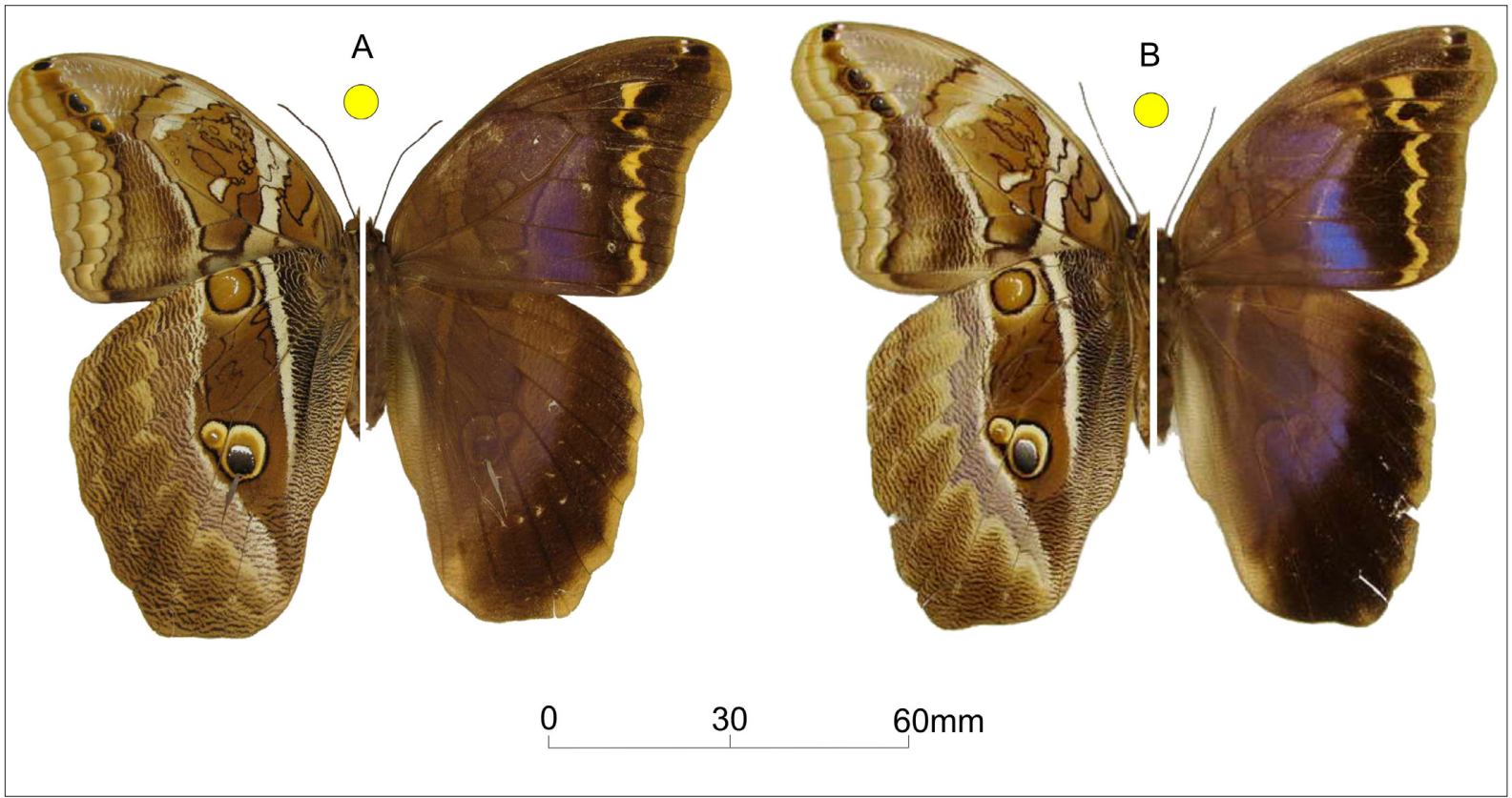

Fig. 8. Habitus of females. Yellow spot: paratype (PT). A. Eryphanis zolvizora reyi ssp. nov., PT (La Chimenea, Barinas, Colombia; MIZA). B. Eryphanis zolvizora isabelae ssp. nov., PT (Colonia Tovar, Aragua, Venezuela; MCC).

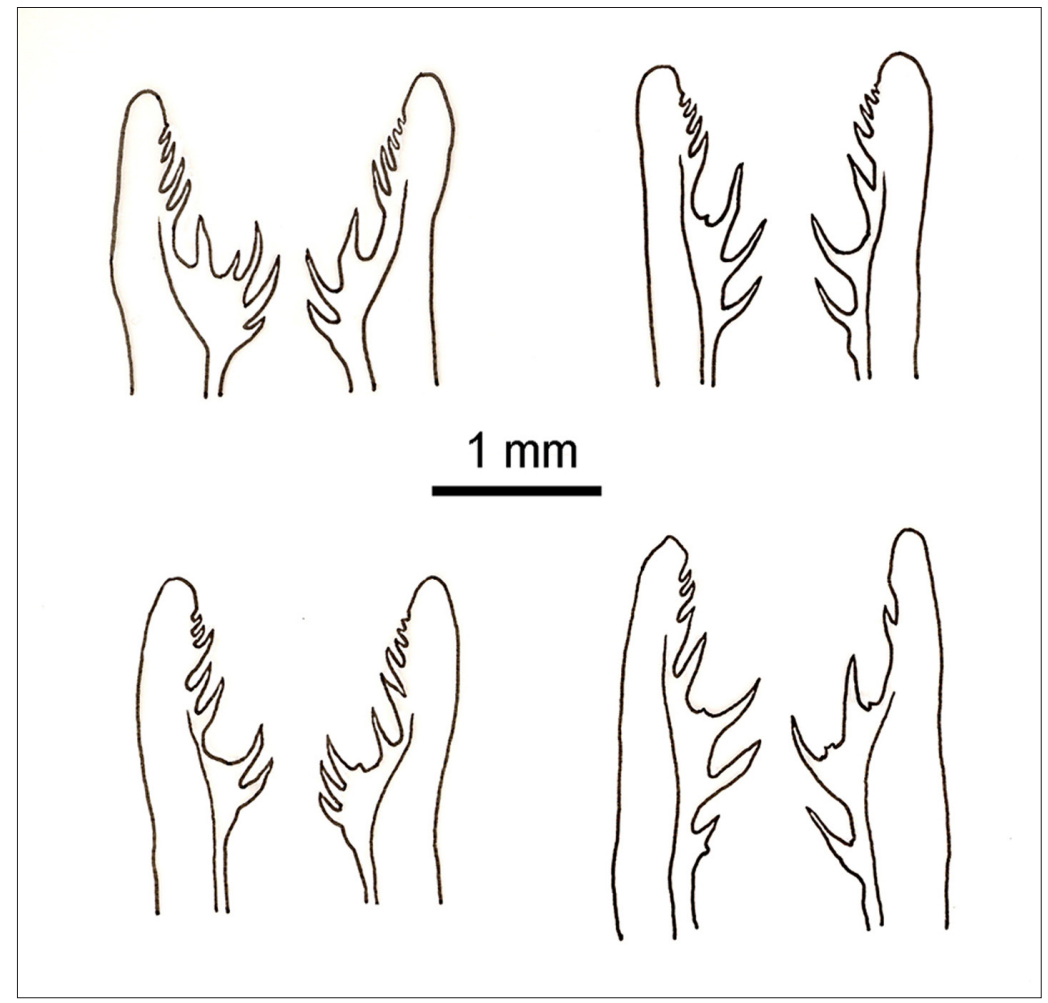

Fig. 9. Inter- and intra-individual variations of the extremities of valvae in a population of E. zolvizora chachapoya ssp. nov. from San José de Molinopampa, Amazonas, Peru (MNHN). 
BLANDIN P. et al., Revision of the Andean Eryphanis zolvizora group

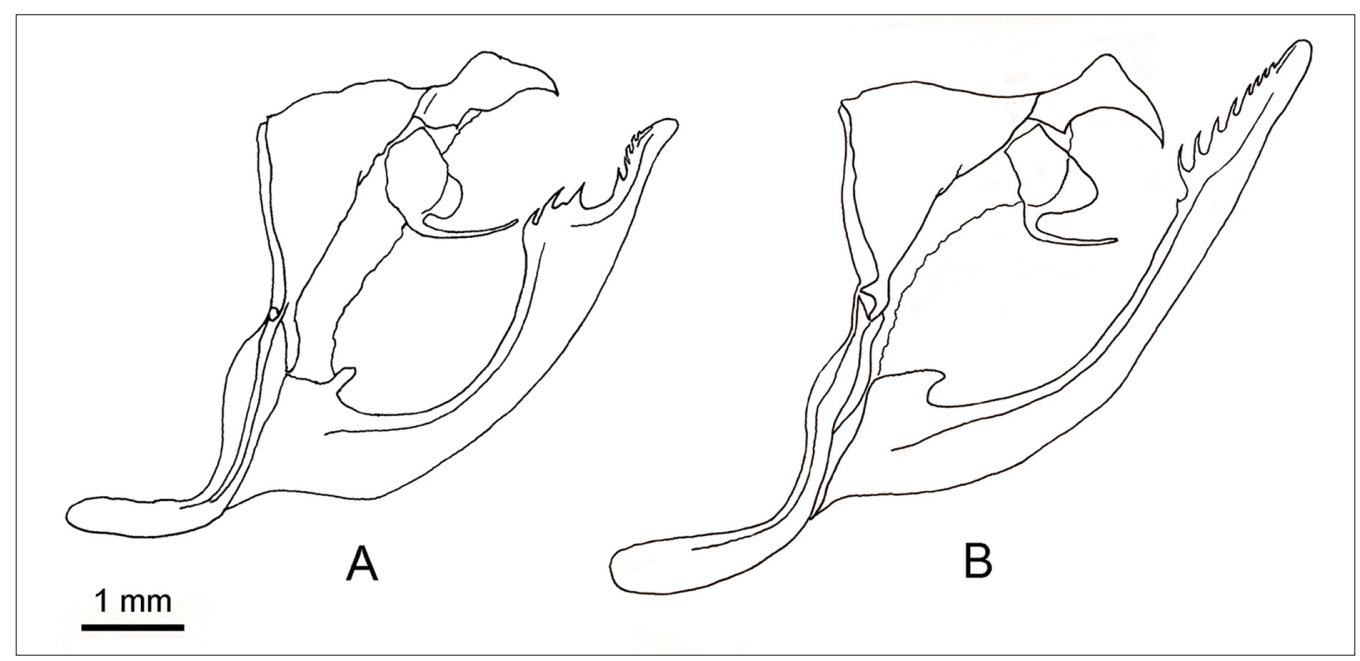

Fig. 10. Male genitalia. A. Eryphanis zolvizora zolvizora (Caranavi, Bolivia; MNHN, PBB 2286). B. Eryphanis zolvizora inca ssp. nov., PT (Llactohuaman, Cusco, Peru; MJP).

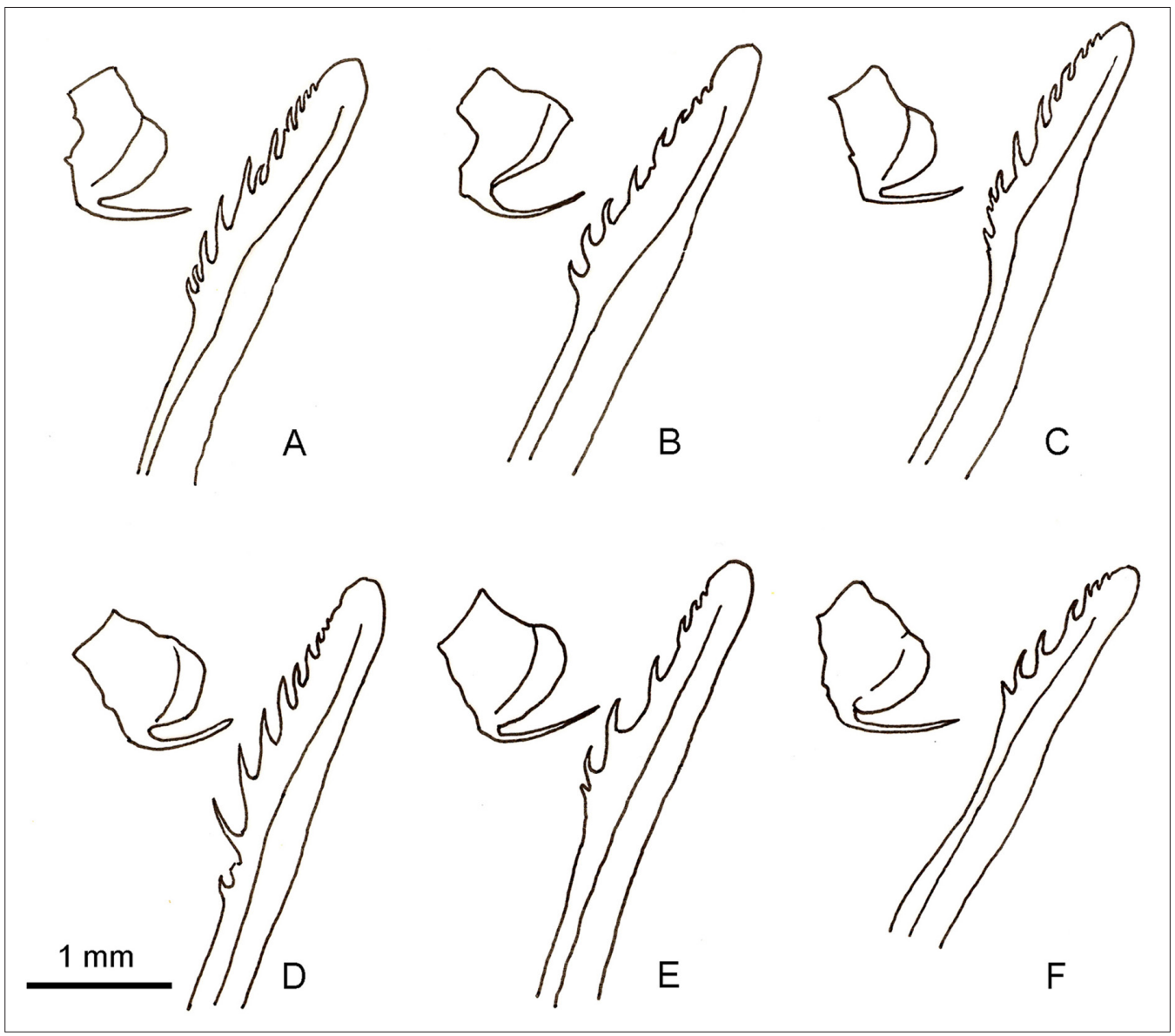

Fig. 11. Gnathos and valva extremity in various specimens of Eryphanis zolvizora inca ssp. nov. A. PT from Santo Domingo, Puno, Peru (BMNH 8223). B. PT from San Lorenzo, Cusco, Peru (MNHN, PPB 2115). C. HT from Aguas Calientes, Cusco, Peru (MJP). D. PT from Alfamayo, Cusco, Peru (MNHN, PBB 2184). E. PT from Calabaza, Junín, Peru (MNHN, PBB 2308). F. Specimen from Oxapampa, Pasco, Peru (MJP).

19 
western Colombia) and Huigra (western Ecuador), on the VFW, a complete connection between the white stripes forms a white "bridge"; the VHW white stripes are longer than in males, but they remain very slightly shorter than in most other females.

Male genitalia (Figs 3A1-A2, 9, 10A-B, 11A-E, 12A-J, 13A-I, 14A-F)

In all specimens, the uncus is humped; the gnathi are more or less quadrangular or trapezoid, with long, narrow and sharp prongs; the valvae are long and globally narrow; dorsally, they show a longitudinal, clearly delimited ridge bearing a row of spines. The phallus has a more or less perpendicular prong anterior to its distal opening, and the distal end of the phallus forms a prong beyond the opening. Diagnostic characters are provided by the gnathi (size and shape) and by the valvae (shape; number and arrangement of spines). It should be emphasized that we have observed individual variations of valvae characters within some populations. Moreover, there are commonly intra-individual differences between the right and left valvae, with variations in spine number (Fig. 9).

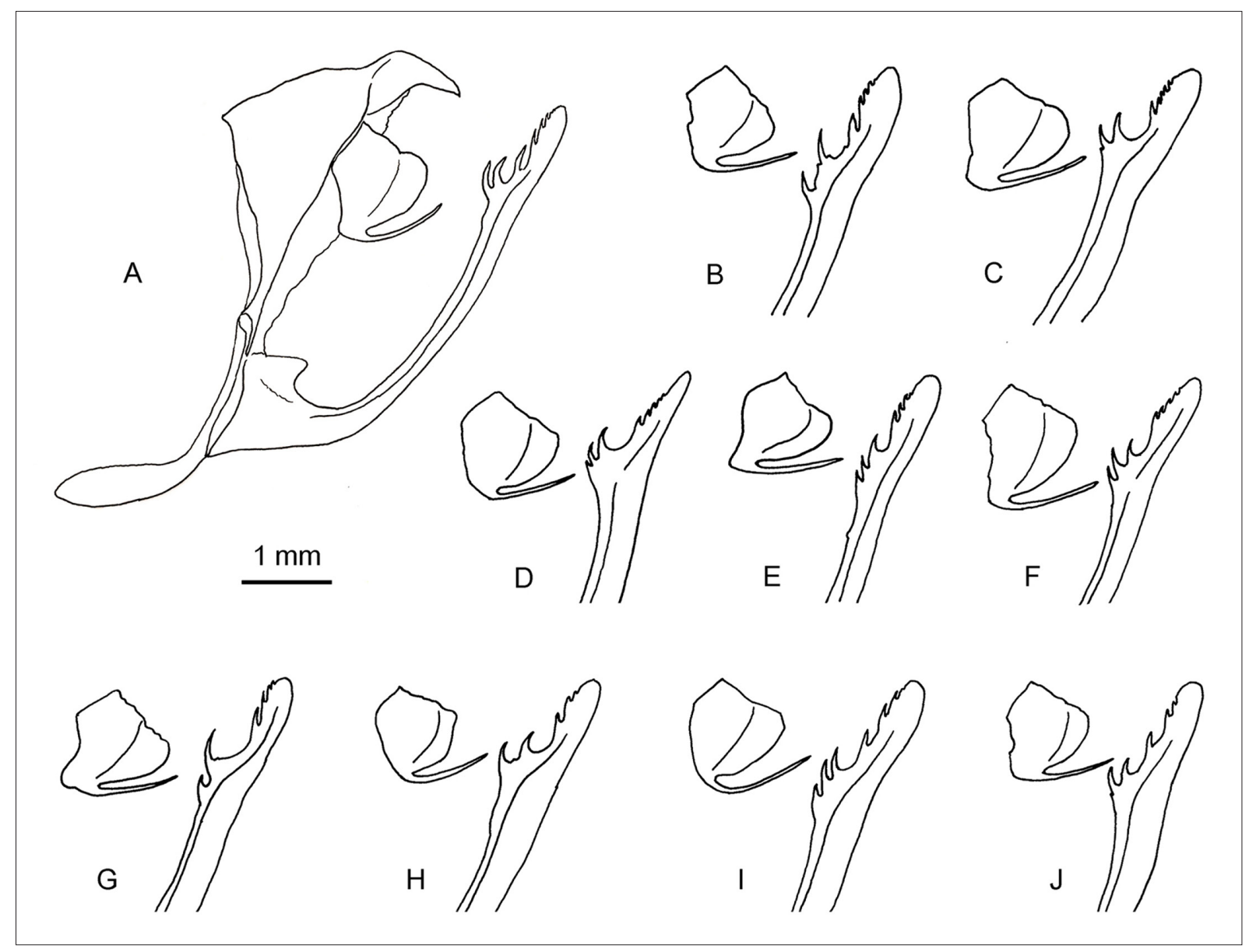

Fig. 12. Male genitalia of various specimens of Eryphanis zolvizora chachapoya ssp. nov. A. PT from San José de Molinopampa, Amazonas, Peru (MNHN, PBGL 190). B. PT from Alto Nieva, Amazonas, Peru (MNHN, PBB 2157). C. Specimen from San Augustín, San Martín, Peru (MNHN, PBGL 521). D. PT from Cumpang, La Libertad, Peru (MJP). E. HT from Huamanpata, Amazonas, Peru (MJP). F. Specimen from Carpish, Huánuco, Peru (MNHN, PBB 2311). G. Specimen from San Francisco, Chanchamayo, Junin, Peru (MNHN, PBB 1407). H. PT from La Suiza, Pasco, Peru (UFPC). I. PT from Huancabamba, Pasco, Peru (BMNH 8224). J. PT from Cushi, Pasco, Peru (BMNH 8225). 
In Bolivian specimens, the valva is characterized by a subterminal swelling, where the ridge has 2-3 strong teeth; beyond the swelling, there is a smooth, rounded gap, followed toward the extremity by a row of small, regular spines. The gnathos is relatively small, the ventral region being reduced, with the prong quite close to the ventral margin (Fig. 3A1).

In specimens from southern and central Peru, the valva is regular, without swelling; the ridge bears a row of more than 6 spines, the size of which varies more or less regularly towards the extremity; the gnathos, as in Bolivian specimens, is smaller than in specimens from northern Peru (Fig. 11A-E). The northernmost specimens presenting these features are labelled "Río Perené" (Junín Department; genitalia MJPZOLV 005PB) and "Oxapampa" (Pasco Department; genitalia MJPZOLV 007PB).

In specimens from northern Peru (Huánuco, La Libertad, Amazonas and San Martín Departments) the gnathos is large, and its ventral region is strongly developed. The valva axis has no swelling, or only a weak one, but the ridge more often has a pronounced swelling, bearing 2-3 very strong spines; distally, there is more often a clear gap, followed by a short distal row of short spines, the size of which reduces towards the extremity (Fig. 12A-J). In central Peru, a specimen labelled "Río Perené" (genitalia MJPZOLV 06PB) and three other specimens (San Francisco, Chanchamayo, Junín, MNHN PBB 1407;

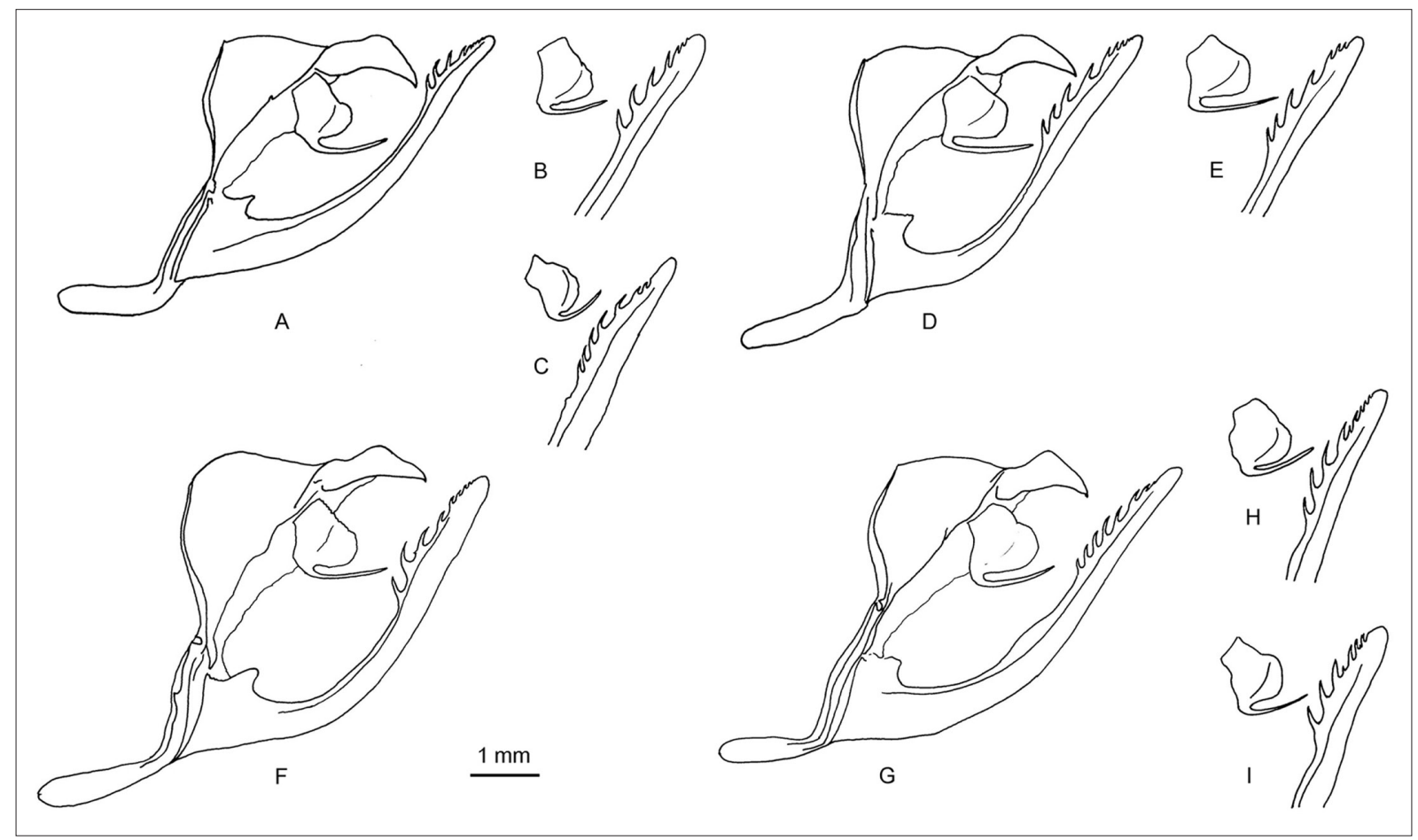

Fig. 13. A-C. Male genitalia of Eryphanis zolvizora greeneyi Penz \& DeVries, 2008, stat. rev. A. Specimen from Rio Blanco, Ecuador (MNHN, PBB 729). B. Specimen from Rio Blanco, Ecuador (MNHN, PBB 537). C. Specimen from Rio Blanco, Ecuador (MNHN, PBB 257). - D-F. Male genitalia of Eryphanis zolvizora casagrande ssp. nov. D. HT from Altaquer, Nariño, Colombia (ICNUN). E. PT from Ricaurte, Nariño, Colombia (IAvH; drawing by Jean-François Le Crom, JFL 336). F. Specimen from Las Gralarias, Pichincha, Ecuador (FLMNH). - G-I. Male genitalia of Eryphanis zolvizora opimus (Staudinger, 1887). G. Specimen from Manizales, Caldas, Colombia (BMNH 8228). H. Specimen from Arménia, Quindio, Colombia (MNHN, CG). I. Specimen from Pereira, Risaralda, Colombia (BMNH 8227). 
Huancabamba, Pasco, BMNH VIAL 8224; and Oxapampa, La Suiza, Pasco, UFPC) present genitalia with similar characteristics (Figs 3A2, 12H).

In eastern Ecuadorian specimens the valva is regular, without swelling; the ridge bears a row of more than 6 spines, the size of which varies more or less regularly towards the extremity. The gnathos is smaller than in specimens from northern Peru, more or less of the same size as those in Bolivia and southern Peru (Fig. 13A-C). The only male we studied from western Ecuador (Fig. 13F), the two males from Nariño (Fig. 13D-E), other Colombian males (Fig. 12G-I) and Venezuelan males (Fig. 14A-F) have similar characteristics, but the gnathos can be larger. Taking into account probable individual variability of valva features, it is not possible to separate either Colombian specimens or Venezuelan specimens from Ecuadorian specimens.

Female genitalia (Figs 3B1-B2, 15A-O)

The sterigma forms a dorsal arch, with two symmetric projections directed inward. These projections are generally divided in one dorsal branch and one shorter ventral branch, of which size and shape are

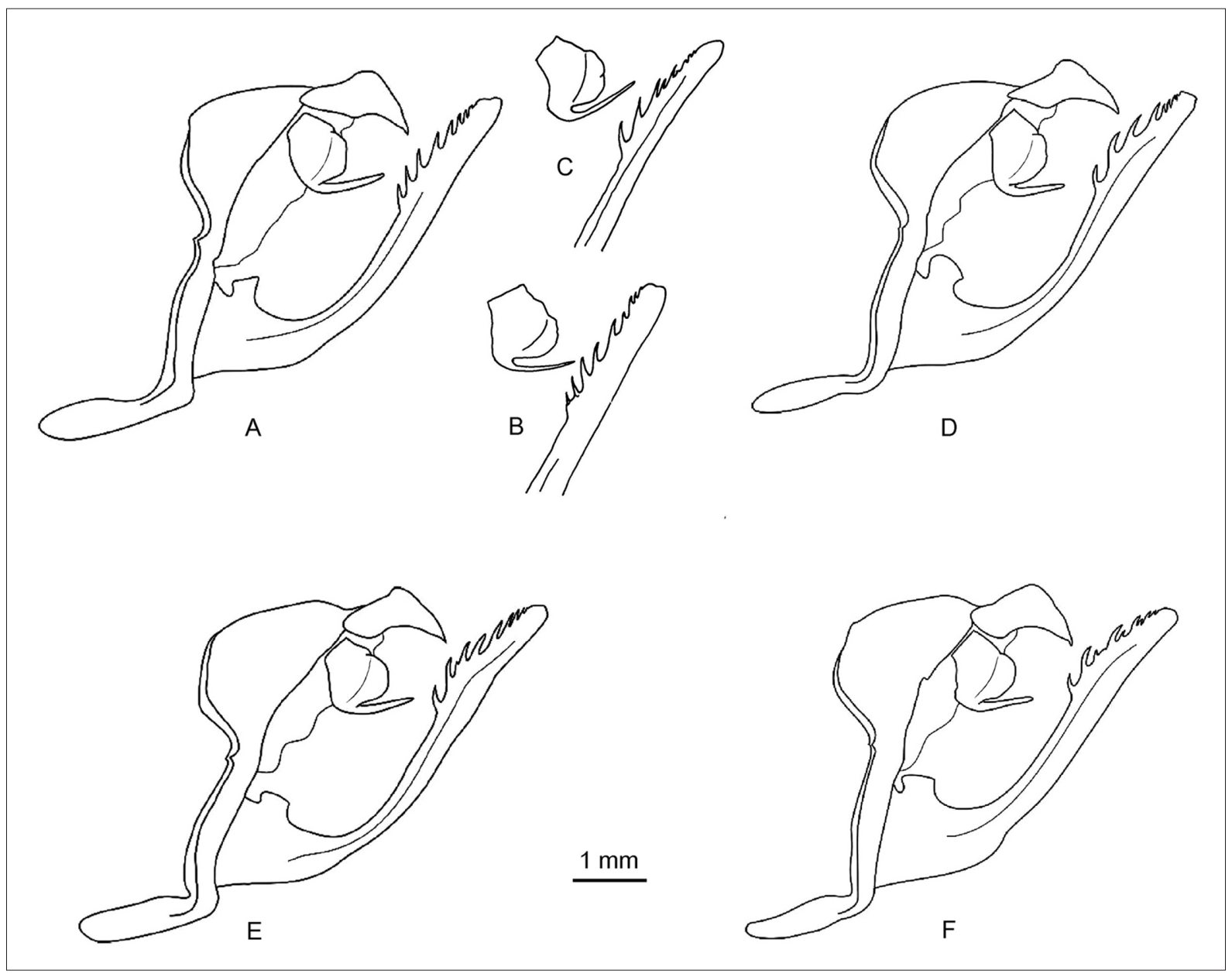

Fig. 14. A-C. Male genitalia of Eryphanis zolvizora reyi ssp. nov. A. PT from La Mina, Barinas, Venezuela (R, 115-JCSC). B. PT from San Isidro, Barinas, Venezuela (MNHN, PBB 2324). C. PT from Charalá, Santander, Colombia (MNHN, PBB 2321). D-F. Male genitalia of Eryphanis zolvizora isabelae ssp. nov. D. PT from Choroní, Aragua, Venezuela (R, 112-JCSC). E. PT from Choroní, Aragua, Venezuela (MIZA, 117-JCSC). F. PT from Choroní, Aragua, Venezuela (R, 111-JCSC). 


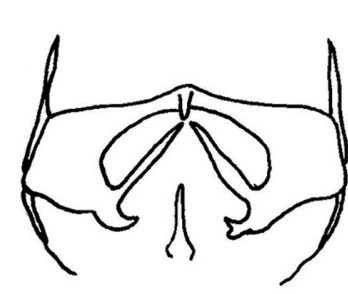

A

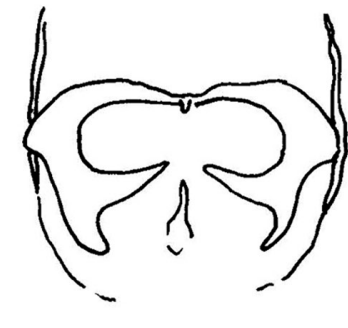

E

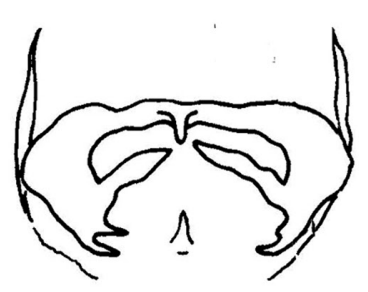

।

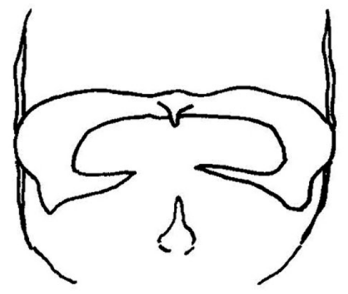

B

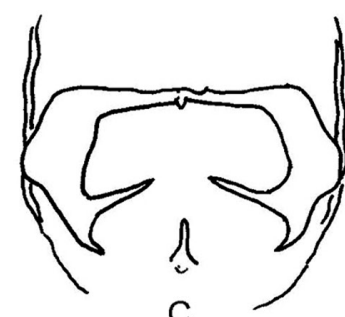

c

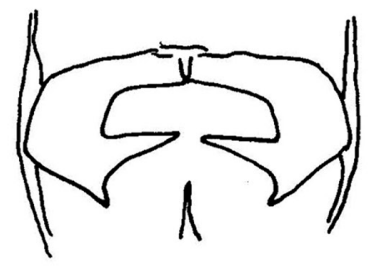

G

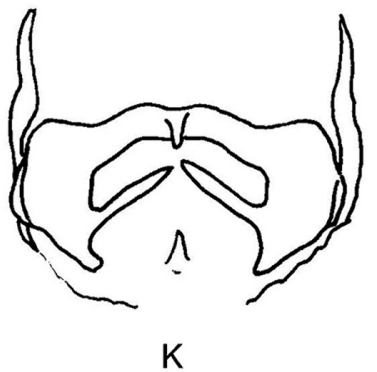

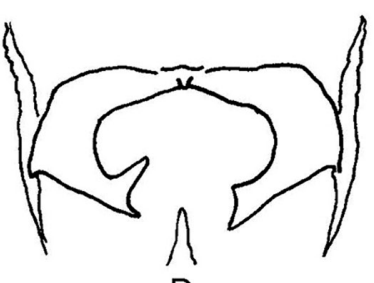

$\mathrm{D}$

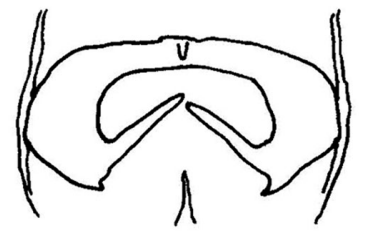

$\mathrm{H}$

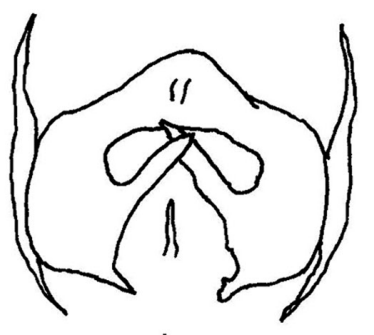

$\mathrm{L}$

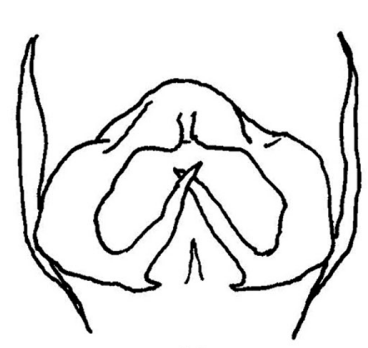

M

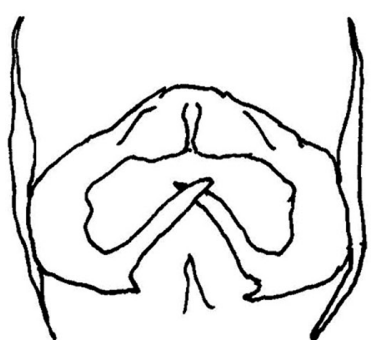

$\mathrm{N}$

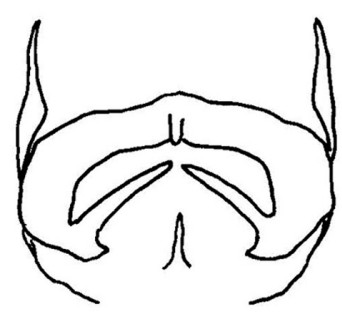

$\mathrm{O}$

Fig. 15. Female sterigma. A. Eryphanis zolvizora zolvizora (Hewitson, 1877) (Bolivia; MNHN, CG). B-H. Eryphanis zolvizora chachapoya ssp. nov. B. PT from Cushi, Pasco, Peru (BMNH 8226). C. PT from Carpish, Huánuco, Peru (MNHN, PBB 2285). D. Specimen from Mallqui, Huánuco, Peru (MNHN, PBB 2327). E. PT from San José de Molinopampa, Amazonas, Peru (MNHN, PBGL 198). F. PT from Nieva, Amazonas, Peru (MNHN, PBGL 596). G. PT from Alto Nieva, Amazonas, Peru (MNHN, PBGL 519). H. Specimen from Alto Nieva, Amazonas, Peru (MNHN, PBGL 520). I. Eryphanis zolvizora greeneyi Penz \& DeVries, 2008, stat. rev., specimen fromValladolid, Zamora-Chinchipe, Ecuador (MNHN, PBB 2288). J. Eryphanis zolvizora casagrande ssp. nov., PT from La Planada, Nariño, Colombia (IAvH; drawing by Jean-François Le Crom, JFL 337). K. E. zolvizora opimus (Staudinger, 1887), specimen from 'Colombie' (MNHN, CG). L. Eryphanis zolvizora reyi ssp. nov., PT from La Mina, Barinas, Venezuela (R, 116-JCSC). M-O. E. zolvizora isabelae ssp. nov. M. PT from Choroní, Aragua, Venezuela (R, 114-JCSC). N. PT from Rancho Grande, Aragua, Venezuela (MIZA, 118-JCSC). O. PT from La Llanada, Distrito Federal, Venezuela (MNHN, PBB 2322). 
variable, probably at the intra-populational level; moreover, specimens sometimes present differences between the two ventral branches. The shape, positioning and orientation of the dorsal branches seem to provide diagnostic characters, but, as there are individual variations, more specimens should be studied for definite conclusions.

Bolivian females ( 2 specimens dissected) have projections with long, narrow and sharp dorsal branches, directed dorsally towards the internal side of the arch; their extremities can cross (Fig. 15A). The Bolivian specimen studied by Penz (2008, fig. 2G) shows similar characteristics. Unfortunately, no southern Peruvian female was available for dissection. In northern Peruvian females $(7$ specimens dissected; Fig.15B-H), the pointed dorsal branches are generally shorter than in Bolivian females, and their extremities are more distant from the internal side of the arch. Nevertheless, there are individual variations, as illustrated by three specimens from the Nieva Valley (Amazonas Department): the sterigma of one specimen is rather similar to those of Bolivian females (Fig. 15H). In the southern Ecuadorian female from Valladolid (Fig. 15I), the dorsal branches are close to the internal side of the arch; moreover, they have notably irregular outlines; these features are rather similar to those of the $E$. greeneyi female figured by Penz (2008, fig. $2 \mathrm{H})$. In the female from Nariño, the dorsal branches are rather similar to those of E. greeneyi, with irregular outlines, but they are more distant from the internal side of the arch (Fig. 15J). In a Colombian female probably coming from the Cauca Valley (Fig. 15K), the dorsal branches have a regular outline similar to northern Peruvian females, but their extremities are notably less distant from the internal side of the arch; nevertheless, the differences with one of the Peruvian females (cf. Fig. 15H) are weak. In one female from the Santo Domingo Valley in western Venezuela, the inward projections are thicker; consequently, the dorsal branches are shorter, but their extremities cross close to the internal side of the arch (Fig. 15L); however, in another female, also from the Cordillera de Mérida, the sterigma is fairly similar to that of the female from the Cauca Valley. On the contrary, in females from the Cordillera de la Costa, the projections are narrower, and the bases of the dorsal branches are widely separated from the internal side of the arch; nevertheless, their extremities are close to it, and can cross (Fig. 15M-O).

\section{One or several species: taxonomic decision}

Considering male genitalia, four groups are clear-cut: a Bolivian group, a southern Peruvian group, a northern Peruvian group, and a Northern Andean group, including populations from Ecuador, Colombia and Venezuela. Female genitalia possibly allow the separation of a Bolivian group, a northern Peruvian group, an eastern Ecuador population, and a Colombian-Venezuelan population (and, possibly, the population from the Cordillera de la Costa). However, as individual variations do exist, as observed in females from northern Peru, more specimens are needed to check the diagnostic role of female genitalia. Consequently, we have established the diagnoses without indicating the characters of female genitalia (but they are described under description sections).

When wing characters are taken into account, the Bolivian, southern and northern Peruvian groups are confirmed, but the Northern Andean group must be divided into an eastern Ecuadorian group, a western Ecuadorian and south-western Colombian group, a group in the Cauca Valley, a group in the northern Colombian eastern cordillera and the Venezuelan Cordillera de Mérida, and a group in northern Venezuela (Cordillera de la Costa). We consider these eight groups as different taxa.

In the present state of knowledge, these geographical groups seem allopatric. Contact or transition zones are not documented. In central Peru, a few specimens suggest a possible geographical overlap between the southern and the northern Peruvian groups. In MJP (coll. Paul Martin), there are two specimens labelled "Río Perené", one belonging to the southern group, the other to the northern group; moreover, in the same collection, there is a specimen of the southern group labelled "Oxapampa", and we know a specimen from the northern group labelled "La Suiza, Oxapampa" (UFPC). Unfortunately, the localities of the 
three specimens in MJP are unreliable (Gerardo Lamas, pers. comm.), making any definite conclusion impossible. However, from the area of Chanchamayo, a classic locality in the Junín Department, there is a specimen of the southern group labelled "Chanchamayo" in the AMNH, and a specimen of the northern group labelled "San Francisco, Chanchamayo" in the MNHN. Moreover, Staudinger's opimus syntype from Chanchamayo (Fig. 4E) probably belongs to the northern group. Therefore, we can conclude that the two groups are both represented in a limited area, and that a geographical overlap is not impossible.

If we consider male genitalia, currently used to separate species in butterfly systematics, it is obvious that Bolivian specimens show clear differences with specimens from southern Peru and other areas. Southern Peruvian specimens have some similarities with specimens from the Northern Andes. Specimens from northern Peru have some unique features in the valvae. Therefore, there are arguments to consider at least four species. However, habitus characters show affinities between Bolivian and southern Peruvian specimens on the one hand, and between Bolivian and Northern Andean specimens on the other. There are also strong similarities between northern Peruvian and eastern Ecuadorian specimens. As a consequence, separations suggested by male genitalia do not fit exactly with separations suggested by the habitus. Therefore, as no sympatry is documented between any pair of neighbouring geographical groups, we chose to classify the E. zolvizora group as one species, divided into eight subspecies: Eryphanis zolvizora zolvizora (Hewitson, 1877) limited to Bolivia; a new subspecies for southern Peruvian populations; another for northern Peruvian populations; E. zolvizora greeneyi (Penz \& DeVries, 2008), stat. rev., for eastern Ecuador; a new subspecies for western Ecuador and southwestern Colombia (Nariño Department); E. zolvizora opimus Staudinger, 1887, from the Cauca Valley; a new subspecies for the north of Colombian eastern cordillera and western Venezuela (Cordillera de Mérida); and a new subspecies for the Venezuelan Cordillera de la Costa.

\title{
Systematics
}

\author{
Class Hexapoda Blainville, 1816 \\ Order Lepidoptera Linnaeus, 1758 \\ Superfamily Papilionoidea Latreille, 1802 \\ Family Nymphalidae Rafinesque, 1815 \\ Subfamily Morphinae Newman, 1834 \\ Tribe Brassolini Boisduval, 1836 \\ Genus Eryphanis Boisduval, 1870
}

The arrangements of the taxonomy of the Eryphanis zolvizora group made in this revision are listed below, modifying the arrangements published by Casagrande (2004) and Penz (2008):

Eryphanis zolvizora (Hewitson, 1877)

zolvizora zolvizora (Hewitson, 1877)

zolvizora opimus Staudinger, 1887

zolvizora greeneyi Penz \& DeVries, 2008, stat. rev.

zolvizora inca Blandin ssp. nov.

zolvizora chachapoya Blandin ssp. nov.

zolvizora casagrande Bristow ssp. nov.

zolvizora reyi Bristow, Neild, De Sousa \& Huertas ssp. nov.

zolvizora isabelae Neild \& De Sousa ssp. nov.

Taxa are presented below in a South-North arrangement because the species was described from Bolivia. Diagnoses are detailed for males, as they have been studied in larger numbers than females. Important diagnostic characters are shared by male and female habitus, except the characters of the male androconial patches. Male genitalia also provide important diagnostic characters. Because of the low 
number of dissected females, and the existence of some important individual variations, female genitalia do not provide obvious diagnostic characters.

Eryphanis zolvizora zolvizora (Hewitson, 1877)

Figs 3A1, 4A-B, 7A, 10A, 15A

Pavonia zolvizora Hewitson, 1877. Illustrations of new species of exotic butterflies selected chiefly from the collections of W. Wilson Saunders and William C. Hewitson. Vol. IV, London, John Van Voorst, (Morphinae: Pavonia II, plate [6]).

Caligo zolvizora - Kirby 1877: 847. - Weymer \& Maasen 1890: 62.

Pavonia zolvizora - Kirby 1879: 110.

Eryphanis zolvizora zolvizora - Stichel 1904: 33; 1909: 157; 1932: 157. — Fruhstorfer 1912: 312. — Casagrande 2004: 203.

Eryphanis zolvizora - D’Abrera 1987: 406. - Penz 2008: 14, figs 1G, 2G, 4G, 5G, 6G (re-description).

\section{Diagnosis}

Poorly developed HW projection (Figs 1a, 4A-B); moderately developed oblique orange spot on DFW between the R5 and M1 veins (Figs 1b, 4A-B); VHW costal ocellus circled by a brown, incomplete ring without white scales (Figs 21, 4A-B); large $\mathrm{Cu} 1-\mathrm{Cu} 2$ ocellus (average widest diameter: 12mm) (Figs $2 \mathrm{~m}, 4 \mathrm{~A}-\mathrm{B})$. The valva is characterized by a subterminal swelling, where the ridge has $2-3$ strong teeth; beyond, a smooth rounded gap followed by a row of small regular spines. Gnathos is relatively small, its ventral region being reduced (Figs 3A1, 10A).

\section{Type material}

\section{Lectotype, here designated}

O, two white labels, printed and written in black: //Bolivia (Buckley) [hand written] Hewitson Coll. 79-69. Pavonia [printed] zolvizora Hew. 2 [hand written]// B.M. Type No. Rh [printed] 6110 Pavonia zolvizora $\widehat{o}^{\Uparrow}$ Hew. [hand written]// (BMNH).

\section{Paralectotype, here designated}

${ }^{2}$, one label, hand written in black: //Hewitson 1// (BMNH).

\section{Type locality}

Bolivia.

\section{Description}

Male

The FWL varies from 57 to $67 \mathrm{~mm}$. The hindwing projection is poorly developed (average $\mathrm{P}=3.3 ; \mathrm{n}$ = 14; cf. Table 3). Between the R5 and M1 veins there is an oblique orange spot forming the proximal branch of the submarginal band. The DFW five submarginal orange spots are large, but clearly separated by the veins (Figs 1c, 4A-B). Their form and size are variable (however, the M3-Cu1 spot is generally triangular, rarely crescent-like), but they are never strongly reduced. The wings on the dorsal surface are dark brown, with a weak violet iridescence on FW and absent on HW (Fig. 4A-B). The androconial patch in the anal area of the DHW is 6.0-8.0 mm long (cf. Table 4); its colour is a bright creamy, pale citrus yellow, sometimes weakly greyish, thus less bright (Fig. 4A-B). The underside is strongly patterned (Fig. 4A-B); the ochre-brown background often shows a yellowish tinge on the distal part of the wings, notably on FW margins; the colour of the median area is a contrasting ochre-brown. In the VFW cell, the isolated white spot is more often small or medium; however, it is sometimes elongated and in contact with a chain of whitish spots connected with the white distal limit of the cell (Figs 2g, 4A-B). There is no 
white spot in the angle formed by the cubital vein of the VFW cell and $\mathrm{Cu} 2$, or it is extremely small (Figs 2h, 4A-B). On the VFW, the two white stripes are clearly separated in the cell Cu2-2A; the inner margin of the distal stripe, which generally forms a small, blunt tooth, is underlined by a thick black line (Figs 2i, 4A-B). On the VHW, the white stripes extend far beyond the $\mathrm{Cu} 1-\mathrm{Cu} 2$ ocellus, notably the distal one, which reaches vein $2 \mathrm{~A}$ (Figs 2j, 4A-B). Dark brown lines are well developed in the HW cell, as well as a dark brown curved line above the $\mathrm{Cu} 1-\mathrm{Cu} 2$ ocellus (Figs 2k, 4A-B). The VHW costal ocellus is circled by a brown, incomplete ring, a little paler than the median area; there are no white scales on this ring; the black ring is generally complete (Fig. 4A-B). The Cu1-Cu2 ocellus is large (Fig. 4B); its widest diameter $(\Phi)$ generally varies between 10.5 and $14.5 \mathrm{~mm}$ (cf. Table 5; NB: in the lectotype, the ocellus is relatively small, see Fig. 4A, an uncommon feature). The genitalia do not present significant individual variations.

\section{Female}

The FWL varies from 62 to $68 \mathrm{~mm}$. The hindwing projection is as reduced as in males. The basal $2 / 3^{\text {rd }}$ of the dorsal surface is a lighter brown than in males, with a distal violet tinge on the DFW and DHW, brighter than in the male (Fig.7A). On the DFW, the orange spots exhibit the same characteristics as in males. The ventral surface can be lighter than in males, notably on the distal parts (Fig. 7A), but some specimens are hardly different from males. The sterigma has inward projections with short, pointed ventral branches (sometimes with 2 points) and long, narrow dorsal branches which are dorsally oriented and can cross in the middle (Fig. 15A).

\section{Flight periods}

Eryphanis z. zolvizora has been collected from January to May and from September to November.

\section{Distribution}

Bolivia. For a long time, the distribution of E. z. zolvizora was poorly known, as most specimens had been essentially collected near the roads from Cochabamba to Villa Tunari (Cochabamba Department), and in some localities in the "Coroico - Caranavi" area (La Paz Department). Recent collecting by Bolivian entomologists has provided new localities, notably in Santa Cruz Department, where the area of Manchones represents the southernmost locality (ca. 18 ${ }^{\circ} 45^{\prime} \mathrm{S}$ ) known. Reliable altitudes range from $1000 \mathrm{~m}$ to $2600 \mathrm{~m}$. We suppose that E. z. zolvizora exists locally in all cloud forests along the northern part of the Bolivian Andes. Referring to Fruhstorfer (1912), Penz (2008) suggests that perhaps $E$. zolvizora (E. z. zolvizora according to our conception) reaches southern Peru. However, all specimens we know from southern Peru (Puno Department) belong to E. z. inca ssp. nov. Nevertheless, it should be noted that there is no information about populations existing near the Bolivian-Peruvian border.

\section{Remarks}

The species name zolvizora (originally described in the genus Pavonia) was authored by Hewitson in his Illustrations of new species of exotic butterflies selected chiefly from the collections of W. Wilson Saunders and William C. Hewitson, issued in five volumes between 1852 and 1877 (Lamas et al. 1995). The date of publication of zolvizora is variously given as 1876 (e.g. in Stichel 1909) or 1877 (e.g. in Lamas et al. 1995), and the volume of the publication is given as IV (published 1867-1871 according to the date on the title page) (Stichel 1932) or V (published 1872-1876 according to the date on the title page) (Stichel 1909; Lamas et al. 1995). The contents of the 5 volumes of 'Illustrations' were issued, unpaginated (1286 pp - including blank pages and 300 plates), in a series of unnumbered parts. The text for zolvizora is on the reverse of the page with Pavonia seleucida which has 'Published January $1^{\text {st }}$ 1877' printed at the bottom. Two copies of 'Illustrations' inspected by the authors (at the USNM Library available online (www.biodiversitylibrary.org) and in the UMO Library, Oxford), have the text preceded by two plates. However, two copies inspected at the BMNH, including Lord Rothschild's bequest copy, 
have the text before the plates. The first plate is of P. seleucida (with the page note 'W.C. Hewitson del et lith Oct. 1876'), the second of P. zolvizora (with the page note 'W.C. Hewitson del et lith Nov. 1876 '). The original copy acquired by the BMNH has the date of publication of the text of P. zolvizora pencilled in as '1.i.1877' (recorded also in Griffin 1932). The USNM copy has the dates of publication of the plates pencilled in as Jan. 11877 (presumably after Griffin 1932). This date for plates and text would suggest that they belong to Vol. V, but in the Systematic Index for all five volumes Pavonia I ([pl. 5], P. seleucida) and II ([pl. 6], P. zolvizora) are clearly part of Vol. IV, supposedly published 1867-71. However, in Vol. 5, under 'CORRECTIONS' it states that 'An index is given by which the binder will be able to arrange the plates'. It is possible that some copies of The Illustrations were bound in the order that they were issued or acquired by the different libraries, which could account for Pavonia being included in Vol. V, rather than in Vol. IV where the Index indicates it was intended to be published. In summary, as the plates and parts in the various volumes of the 4 sets examined were not bound in order as they were issued, but according to the order laid down by Hewitson, it seems to us to be correct to regard P. zolvizora as part of Vol. IV (as in all 4 copies examined), and we regard the name P. zolvizora to have been published on the 1 Jan. 1877 (but see Lamas et al. 1995).

The specimen identified as the type of E. zolvizora at the BMNH, a male collected by C. Buckley (Fig. 4A), has no precise locality, being labelled as follows: "Bolivia (Buckley) Hewitson Coll. 79-69. Pavonia zolvizora Hew. 2". Following Kirby's catalogue of Hewitson's Butterflies at the BMNH (Kirby 1879: 110), it is known that there is another specimen labelled 'Hewitson 1', part of the type series at the BMNH; it was found during recent curation conducted by $\mathrm{BH}$. Therefore, these two specimens are syntypes. The specimen we have chosen to be the lectotype was formerly considered to be the holotype. Consequently, the second specimen is a paralectotype.

Eryphanis zolvizora inca Blandin ssp. nov.

Figs 4C, 10B, 11

\section{Diagnosis}

On the DFW, the R5-M1 orange mark is more or less faded, sometimes missing (Fig. 4C); HW projection slightly pronounced (Fig. 4C); VHW costal ocellus is circled by a brown incomplete ring without white scales (Fig. 4C); on VHW, the widest diamaeter of the Cu1-Cu2 ocellus averages $12 \mathrm{~mm}$ (Fig 4C). The valva is regular, without swelling; the dorsal ridge bears a row of more than 6 spines, the size of which varies more or less regularly; gnathos is small (Figs 10B, 11).

\section{Etymology}

The holotype was collected by Dr. Gerardo Lamas close to Machu Picchu, the emblematic site of the famous Inca civilization, in the Cusco area.

\section{Type material (14 specimens)}

\section{Holotype}

PERU: $\widehat{0}$, white label printed in black: // PERU - CU [Cusco]- Aguas Calientes $2050 \mathrm{~m} \mathrm{1309-7231}$ [1309’S 72³1’W] 21.x.2001 [21 Oct. 2001] G. Lamas// (MJP).

\section{Paratypes}

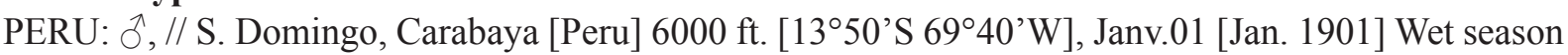

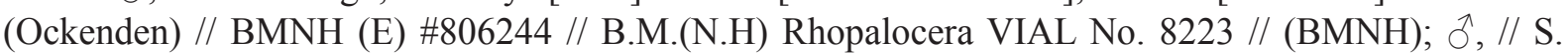
Domingo, Carabaya [Peru], $4500 \mathrm{ft}$. [13 $50^{\circ} \mathrm{S} 69^{\circ} 40^{\prime} \mathrm{W}$ ], 01 [1901], Dry season, [Ockenden] // BMNH (E) \#808079 // B.M.(N.H) Rhopalocera VIAL No. 8576 // (BMNH); §̊, // S. Domingo, Carabaya [Peru], 4500 ft., [1350'S 6940'W], 01 [1901]. Dry season. [Ockenden] // BMNH (E) \# $808078 / /(B M N H)$;

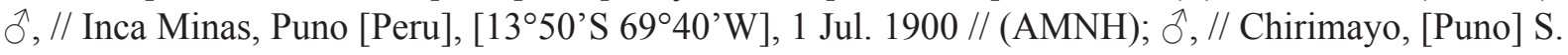


E. Peru. VI.01 [Jun. 1901] Dry [dry season] (Ockenden) $1000 \mathrm{ft}$ [13²7'S 70¹8'W] // BMNH (E) \# 808081 // (BMNH); đ̂, // Inambari, [Puno] Peru // BMNH (E) \# 525986 // (BMNH); đે, // San Lorenzo, Río Marcapata, Cusco, Pérou [Peru] // PBB 2115 // (MNHN, PBB); đ̃, // Llacatahuamán, Quebrada Bagre [Cusco, Peru], 1700 m, [1252’S 73³0’W], 27/07/1998 [27 Jul. 1998], G. Valencia leg. (Cusco)

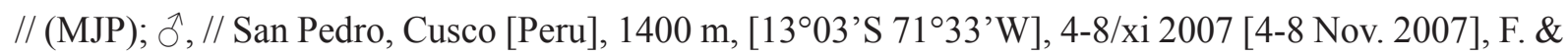
A. West leg. // (MJP); đ̃, // Alfamayo, route [road] Ollantaytambo-Quillabamba, Cusco, Pérou [Peru], M. Cabrera leg. // PBB 2184 // (MNHN, PBB); Õ, // Pérou Marchu Pijchu [sic] [Peru, Machu Picchu] alt. 2000m 10/7/1934 [10 Jul. 1934] A. Larichesy // IRSN IG 10375 // IRSSNB; O̊, // PE. [Peru] 1012 87 [10 Dec. 1987] Macchu Picchu [sic] [Machu Picchu] Coll. J. Dubois // (MNHN, CG); ô, // Calabaza, Pampa Hermosa, Prov. Satipo, Junín, Pérou [Peru] 2200 m, [11²9’2.02”S 7447’39.25”W], Avril 2008 [Apr. 2008] // PBB 2308 // (MNHN, PBB).

\section{Other material examined}

Several specimens are not included as paratypes (data in Appendix 2), notably two males in MJP, labelled respectively "Rio Perené (Junín)" (genitalia MJPZOLV 005PB, MJP) and "Oxapampa (Pasco)" (genitalia MJPZOLV 007PB) as their localities are not reliable (Gerardo Lamas, pers. comm.).

\section{Description}

The FWL varies from 60 to $65 \mathrm{~mm}$. The holotype FWL is $62 \mathrm{~mm}$. The hindwing projection (average $\mathrm{P}=$ $4.4 ; \mathrm{n}=13$; cf. Table 3 ) is more pronounced than in E. z. zolvizora, and less pronounced than in specimens from northern Peru (E. z. chachapoya ssp. nov.). On the DFW the R5-M1 orange mark is more or less faded, sometimes missing. The other orange marks are generally large; the violet iridescence is more pronounced on FW and HW than in E. z. zolvizora and in E. z. chachapoya ssp. nov.; the androconial patch is a creamy, pale citrus yellow (Fig. 4C). The background colour of the ventral surface, as in $E$. z. zolvizora, is less dark than in E. z. chachapoya ssp. nov.; on the VFW, the isolated white spot in the cell is of medium size, more or less oval, or irregular; there is no white spot in the angle formed by the cubital vein of the cell and $\mathrm{Cu} 2$, or it is very small; the inner margin of the distal white stripe on VFW, between $\mathrm{Cu} 2$ and 2A, generally forms a small, blunt tooth (Fig. 4C). On the VHW, the white stripes extend far beyond the $\mathrm{Cu} 1-\mathrm{Cu} 2$ ocellus, notably the distal one, which reaches vein $2 \mathrm{~A}$; in the cell the dark brown lines are generally developed as in E. z. zolvizora, but the dark brown curved line above the $\mathrm{Cu} 1-\mathrm{Cu} 2$ ocellus is sometimes absent; the costal ocellus is circled by a brown incomplete ring, a little paler than the median area and without white scales; the black ring is generally complete (Fig. 4C). On average, the VHW Cu1-Cu2 ocellus is as large as in E. z. zolvizora ( $\Phi$ average value: $12.1 \mathrm{~mm} ; \mathrm{n}=13$; cf. Table 5) and larger than in all other subspecies. The genitalia do not present significant individual variations.

\section{Flight periods}

Specimens have been collected in January, April, June, July and October.

\section{Distribution}

Peru. E. z. inca ssp. nov. extends in southern and central Peru from Puno Department to Junín Department, and possibly to the south of Pasco Department. 
Eryphanis zolvizora chachapoya Blandin ssp. nov.

Figs 3A2, 4D-F, 7B, 9, 12, 15B-H

\section{Diagnosis}

HW projection is strongly pronounced (Figs 1a, 4D, F); on the DFW the R5-M1 orange patch is often missing or very reduced (Fig. 4D-F); on the VFW the two white stripes are generally separated in the cell $\mathrm{Cu} 2-2 \mathrm{~A}$, but the inner margin of the distal stripe forms a projection towards the outer black margin of the proximal stripe (Fig. 4D-F); the dark brown lines on the VHW cell and the curved line above the $\mathrm{Cu} 1-\mathrm{Cu} 2$ ocellus are faint or absent (Fig. 4D-F); the VHW costal ocellus is circled by a clear ring contrasting with the median area; in many specimens it is widely covered with white scales (Fig. 4D-F); large VHW Cu1-Cu2 ocellus (average widest diameter: $10 \mathrm{~mm}$ ). The valva axis has no swelling, or only a weak one; the ridge usually with a pronounced swelling, bearing 2-3 very strong spines; towards the extremity there is more often a gap, followed by a short distal row of short spines diminishing towards the extremity; gnathos is large and its ventral region is strongly developed (Fig. 12).

\section{Etymology}

Named after the pre-Inca Chachapoya civilization which existed in northern Peru, mainly in the present Amazonas and San Martín Departments; the Chachapoyas were also called "Warriors of the Clouds".

\section{Type material (23 specimens)}

\section{Holotype}

PERU: $\widehat{\delta}$, a white label printed in black ink: // PERU, AM [Amazonas], Valle de Huamanpata, Lejia

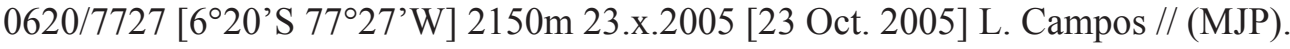

\section{Paratypes}

PERU: đ̃ , // San Francisco, Chanchamayo, Junín, Pérou, Jan. 1964, Mme Harris leg. // PBB 1407 //

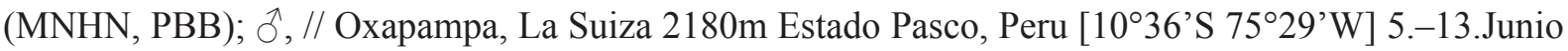

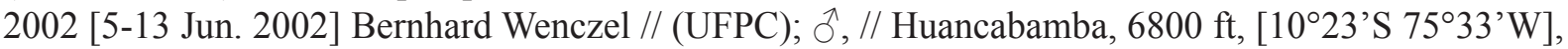
Pasco [Peru] // BMNH VIAL 8224 // BMNH (E)\# 806245 // (BMNH); đ, // Cushi [Pasco, Peru], 1820 m, (W. Hoffmans) // BMNH (E)\# 806246; VIAL 8225 // (BMNH); ô, // Cushi [Pasco, Peru], 1900 m,

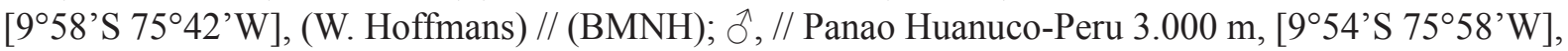
I-1982 [Jan. 1982] Schunke Leg // (UFPC); Õ, // Carpish, 2300 m, Huánuco, Pérou, Jan. 2006 // PBB

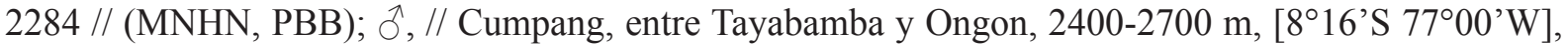
21/10/79 [21 Oct. 1979], T. Parker, leg. (La Libertad) [Peru] // genitalia MJPZOLV 004PB // (MJP); Oૈ, // Environs de Mendoza, [06²3'S 77²7W], Amazonas, Pérou, Jun. 1994, B. Calderón leg.// PBB 1900

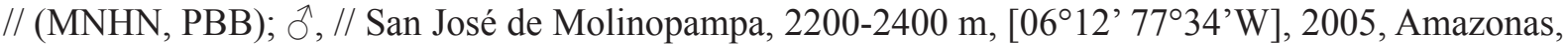
Pérou, B. Calderón leg. // PBGL 166 // (MNHN, CG); ô, // San José de Molinopampa, 2200-2400 m, [06²' ${ }^{\circ} 77^{\circ} 34^{\prime} \mathrm{W}$ ], 2008, Amazonas, Pérou // PBB 2309 // (MNHN, PBB); Ô, // Le long de l'alto río Nieva, 2250 m, [0542'40”S 7747'15”W], 4-9 Mar. 2009, Amazonas, Pérou, José Ananias Tafur leg.

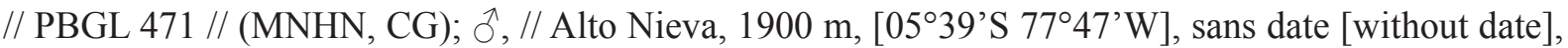

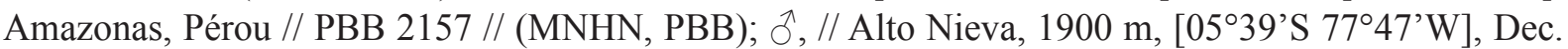
2012, Amazonas, Pérou, Joël Clever Pintado leg. // PBGL 706 // (MNHN, CG); ठ̊, // Villa Hermosa, 1500 m, [05³6’S 77²7'W], Dec. 2010, Amazonas, Pérou, Joël Clever Pintado leg. // PBGL 594 // (MNHN,

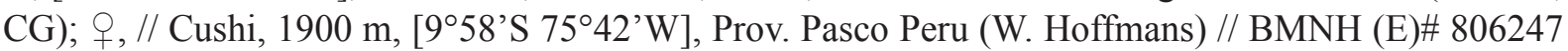
VIAL 8226 // (BMNH); + , // Carpish, 2300 m, Huánuco, Pérou, Jul. 2005 // PBB 2285 // (MNHN, PBB); ㅇ, // San José de Molinopampa, 2200-2400 m, [6 $\left.6^{\circ} 12^{\prime} \mathrm{S} 77^{\circ} 34^{\prime} \mathrm{W}\right], 5$ Jan. 2007, Amazonas, Pérou, B. Calderon leg. // PBGL 198 // (MNHN, CG); , // Alto Nieva, 1900-2000 m, [5³9’00”S 7746’30”W], Mar. 2010, Amazonas, Pérou, Joël Clever Pintado leg. // PBGL 519 // (MNHN, CG); ㅇ, // Nieva, 1900 m, [540’S 77³6’W], Sep. 2011, Amazonas, Pérou, Joël Clever Pintado leg. // PBGL 596 // (MNHN, 
CG); + , río Jenesis [sic], env. 1400 m, [5³2-33’S 77²48-49’W], 11/2012 [Nov. 2012], Amazonas, Peru,

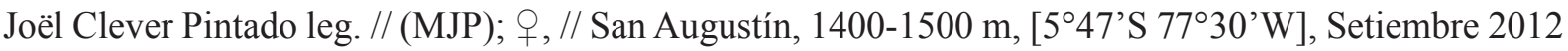
[Sep. 2012], San Martín, Peru, Joël Clever Pintado leg. // (MJP).

\section{Other material examined}

Data on the 21 specimens not included in the paratypes are given in Appendix 2. Among them, a male in MJP, labelled "Rio Perené (Junín)" (genitalia MJPZOLV 006PB) has an unreliable locality (Gerardo Lamas, pers. comm.). One of the syntypes of E. z. opimus from Chanchamayo (in ZMHB) has the HW projection as well developed as in E. z. chachapoya ssp. nov. (estimated value of P index: 5.8). The inner projection of the distal white stripe on VFW is well developed. The ring of the VHW costal ocellus is whitish and contrasts strongly with the brown median area, and the diameter of the $\mathrm{Cu} 1-\mathrm{Cu} 2 \mathrm{VHW}$ ocellus is $10.5 \mathrm{~mm}$. These features are comparable with E. z. chachapoya ssp. nov., but not with $E$. $z$. inca ssp. nov.

\section{Description}

\section{Male}

The FWL varies from 55 to $65 \mathrm{~mm}$. The holotype FWL is $61 \mathrm{~mm}$. Average $\mathrm{P}=5.5(\mathrm{n}=27$; cf. Table 3). On the DFW the R5-M1 orange patch is often missing or very reduced. The other orange marks are well separated; their size is very variable; the violet iridescence is less pronounced than in E. z. inca ssp. nov.; the androconial patch is a bright creamy, pale citrus yellow (Fig. 4D-F). The background colour of the ventral surface is generally darker than in E. z. inca ssp. nov.; the isolated white spot in the VFW cell is of medium size, more or less oval, or irregular; there is no white spot in the angle formed by the cubital vein of the VFW cell and Cu2, or it is extremely small (Fig. 4D-F). On the VFW the two white stripes are generally separated in the cell $\mathrm{Cu} 2-2 \mathrm{~A}$; nevertheless, the inside margin of the distal stripe forms a marked inner projection, which often connects with the outside black margin of the proximal stripe (Fig. 4E); exceptionally ( 3 of 35 specimens), the projection is filled with white scales and forms a complete bridge between the two white stripes, as in E. z. casagrande ssp. nov. (Fig. 2i). On the VHW, the white stripes extend far beyond the $\mathrm{Cu} 1-\mathrm{Cu} 2$ ocellus, notably the distal one, which reaches vein $2 \mathrm{~A}$. The dark brown lines on the VHW cell and curved line above the $\mathrm{Cu} 1-\mathrm{Cu} 2$ ocellus are very faint or even absent (Fig. 4D-F). The VHW costal ocellus is circled by a clear ring contrasting with the median area; moreover, in many specimens it is widely covered with white scales (Figs 21, 4D-F). On average, the VHW Cu1-Cu2 ocellus ( $\Phi$ average value: $10.0 \mathrm{~mm} ; \mathrm{n}=31$; cf. Table 5 ) is clearly smaller than in $E$. z. inca ssp. nov. (Fig. 4D-F). The valva axis has no swelling, or only a weak one; the ridge more often has a pronounced swelling, bearing 2-3 very strong spines; towards the extremity, there is more often a clear gap, followed by a short distal row of short spines, the size of which reduces towards the extremity; gnathos is large, and its ventral region is strongly developed (Fig. 12). Individual variations of the valvae have been observed within a local population, but diagnostic characters are not blurred (cf. Fig. 9).

\section{Female}

The FWL varies from 61 to $67 \mathrm{~mm}$. Diagnostic characters correspond to those of the males (Fig. 7B). The violet iridescence is limited but bright. The underside is lighter than in males. The dorsal branches of the sterigma inner projections are generally shorter than in E. z. zolvizora and E. z. greeneyi, and they are more separated from the internal side of the arch; nevertheless, there are individual variations, and one specimen has the sterigma similar to that of E. z. zolvizora specimens (Fig. 15B-H).

\section{Flight periods}

Specimens have been collected in January, March, June, July, September, October, November and December. 


\section{Distribution}

Peru. E. z. chachapoya ssp. nov. is distributed from Junín Department (central Peru) to Amazonas and San Martín Departments (northern Peru).

\section{Remarks}

This taxon is created for populations from central to northern Peru, which are clearly distinct from E. $z$. zolvizora and E. z. inca ssp. nov. considering wing characters as well as genitalia. Wing characters are closer to the Ecuadorian E. z. greeneyi, but the male genitalia are clearly distinct.

Eryphanis zolvizora greeneyi Penz \& DeVries, 2008 stat. rev. Figs 5A-B, 7C, 13A-C, 15I

Eryphanis greeneyi Penz \& DeVries, 2008; Penz 2008: 15-17, figs 1H, 2H, 4H, 5H, $6 \mathrm{H}$.

\section{Diagnosis}

HW projection strongly pronounced (Fig. 5A); on the DFW the R5-M1 orange patch is usually missing or very reduced; the isolated white spot in the VFW cell is medium to large (Fig. 5A-B); on the VFW, in space $\mathrm{Cu} 2-2 \mathrm{~A}$, the inner tooth of the distal stripe forms a black point which may just connect with the outer black margin of the proximal stripe (Fig. 5B); in the VHW cell and above the $\mathrm{Cu} 1-\mathrm{Cu} 2$ ocellus, faint dark brown lines are generally visible; the VHW costal ocellus has a narrow, bright white outer ring (Fig. 5A-B). The valva axis has no swelling; the dorsal ridge has a row of more than 6 spines, diminishing towards the extremity (Fig. 13A).

\section{Type material}

\section{Holotype}

ECUADOR: đ̂, three labels: // Ecuador, Napo, Yanayacu Biological Station, 5km W of Cosanga, May 2007// reared on Chusquea scandens, H. F. Greeney// Eryphanis grteeneyi Penz and DeVries HOLOTYPE// (BMNH).

\section{Paratypes}

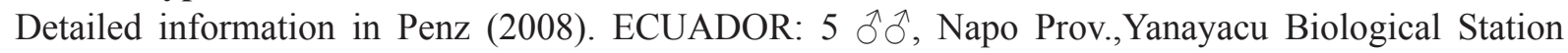
(BMNH); Provincia Napo (MECN); Provincia Napo (AMNH); Rio Blanco, near Baños, (DeVries Collection, USA); Balzapampa, Ecuador (FLMNH). 4 우, Napo, Yanayacu Biological Station (BMNH); Napo Prov., Yanayacu Biological Station (MECN); Napo, Biol. Yanayacu (AMNH); Provincia Napo, San Isidro (DeVries Collection, USA).

\section{Type locality}

Ecuador, Napo Province, Cosanga.

\section{Description}

Male

The FWL varies from 55 to $66 \mathrm{~mm}$ (our data, and according to Penz 2008). Average $\mathrm{P}=5.5$ ( $\mathrm{n}=11$; cf. Table 3), as in E. z. chachapoya ssp. nov., differing in this way from other subspecies from the Northern Andes. On the DFW the R5-M1 orange patch is more often missing or very reduced; the other orange marks are well separated, at least by the veins; their size is very variable; the violet iridescence is fainter than in E. z. chachapoya ssp. nov.; the androconial patch is a bright creamy, pale citrus yellow (Fig. 5A-B). The underside is close to that of E. z. opimus as it is generally lighter, with a more yellowish tint, than in E. z. chachapoya ssp. nov. (Fig. 5A); however, there are intermediate specimens, which resemble more closely specimens of E. z. chachapoya ssp. nov. (Fig. 5B). On the VFW, the isolated white spot in 
cell is medium to large, with an irregular, more or less quadrangular, triangular or oval shape; there is no white spot in the angle formed by the cubital vein of the cell and $\mathrm{Cu} 2$, or it is very small (Fig. 5A); on the VFW, in space Cu2-2A, the inner tooth of the distal stripe is well developed, forming a black point which in some specimens forms a narrow black bridge with the outside black margin of the proximal stripe (Fig. 5A-B). On the VHW, the white stripes extend far beyond the $\mathrm{Cu} 1-\mathrm{Cu} 2$ ocellus, notably the distal one, which reaches vein $2 \mathrm{~A}$; in the cell and above the $\mathrm{Cu} 1-\mathrm{Cu} 2$ ocellus, the dark brown lines are generally visible, but very faint in some specimens; the VHW costal ocellus has a narrow, bright white outer ring (sometimes the white scales do not cover the ring entirely); the black ring is generally complete (Fig. 5A-B); the widest diameter of the $\mathrm{Cu} 1-\mathrm{Cu} 2$ ocellus has an average value of $9.5 \mathrm{~mm}(\mathrm{n}$ $=11$; cf. Table 5). Genitalia exhibit weak individual variations (Fig. 13A-C). The valva axis has no swelling, and the dorsal ridge bears a row of more than 6 spines, decreasing in size more or less regularly towards the extremity; in that way, E. z. greeneyi strongly differs from E. z. chachapoya ssp. nov., while it is similar to Colombian and Venezuelan subspecies. The gnathos is smaller than in E. z. chachapoya ssp. nov., but its size probably falls within the range of individual variations in E. z. opimus.

Note. The five orange spots that comprise the FW band vary in size. In the holotype from Yanayacu, the three lower spots are crescentic and just touch; in others, the spots are smaller, less obviously crescentic and do not touch. Both types of FW band are seen in Río Blanco specimens and it is assumed that they represent individual variation. A more extreme example is the male figured by Piñas (2004, figs 653 and 654) from Baeza, where the FW spots are large and contiguous (Fig. 5B). As Baeza lies fairly close to Yanayacu, it is assumed that this phenotype falls within the variation of E. z. greeneyi.

\section{Female}

The FWL varies from 64 to $68 \mathrm{~mm}$ (our data and after Penz 2008). Considering the habitus (Fig. 7C), the diagnostic characters correspond to those of the males, except the size of the $\mathrm{Cu} 1-\mathrm{Cu} 2$ ocellus, which can be large $(\Phi=11.5 \mathrm{~mm}$ in a female from Valladolid). The violet iridescence is limited but bright on both the FW and HW. The underside is lighter than in males. The dorsal branches of the sterigma are close to the internal side of the arch. Moreover, they have marked irregular outlines; in that way, E. $z$. greeneyi differs from other subspecies.

\section{Flight periods}

E. z. greeneyi appears to fly throughout the year, with May being the commonest month of capture.

\section{Distribution}

Ecuador. Eryphanis z. greeneyi extends throughout eastern Ecuador (possibly extending into southern Colombia) at altitudes generally between 1500 and $2220 \mathrm{~m}$, but there are some records (if genuine) which suggest that it may occur as low as $600 \mathrm{~m}$. It is well known from the much-collected area of the upper Río Pastaza between the Río Blanco and Río Verde and extends to the extreme south of Ecuador (Podocarpus, Valladolid and Cordillera Llagunillas). A specimen in MZUJ is labelled from E1 Oro Province, near Balsas; however, it is likely that this specimen had been mislabelled, as it belongs to material donated by K. Jasiński (Keith Willmott, pers. comm.).

\section{Remarks}

The taxon Eryphanis greeneyi, described as a distinct species, was based on 7 males and 4 females, of which several were reared by H.F. Greeney at the Yanayacu Biological Station, near Cosanga, Ecuador (Napo Province). The holotype (a male) and a female paratype are deposited in the BMNH. The name was given in honour of the naturalist Harold Francis Greeney III, who first reared this taxon.

Two males labelled 'Caqueta' in the Le Crom collection were probably collected on the road from Altamira to Florencia at a height of between 1500 and 2000 m (J.F. Le Crom, pers. comm). No other $E$. 
zolvizora specimen is known from eastern slopes of the Colombian Cordillera Oriental. These two males are somewhat darker than most other Colombian specimens. Geographically, they are closest to E. $z$. greeneyi from Ecuador, to which we putatively attach them; however, the HW projection at $\mathrm{Cu} 1$ is only poorly developed and there is no narrow white line surrounding the costal HW ocellus.

Eryphanis zolvizora casagrande Bristow ssp. nov.

Figs 5C-D, 7D-E, 13D-F, 15J

\section{Diagnosis}

HW projection only poorly developed; no R5-M1 orange mark on DFW (Fig. 5C); there is a wide bridge in space $\mathrm{Cu} 2-2 \mathrm{~A}$ on the VFW formed by a complete white connection between the white stripes (Figs 2i, 5C); the isolated white spot in the VFW cell is quite large and semicircular; the narrow outer white stripe on the VHW only just extends down to the smaller of the lower ocelli; the broader inner white stripe only extends as far as the larger of the lower ocelli (Fig. 5C); the dark brown lines in the VHW cell and curved line above the $\mathrm{Cu} 1-\mathrm{Cu} 2$ ocellus are well developed, the distal lines form two conjoined elongate circles (Fig. 5C). The valva axis has no swelling; the dorsal ridge has a row of more than 6 spines, diminishing towards the extremity (Fig. 13D).

\section{Etymology}

Named after Prof. Dr. Mirna Casagrande (Universidade Federal do Paraná, Curitiba, Paraná, Brazil) in recognition of all her work on the brassolines.

Type material (3 specimens)

\section{Holotype}

COLOMBIA: $\widehat{\alpha}$, four white labels printed in black: // Nariño, Barbacoas, Altaquer, Reserva Río Ñambi. [1 ${ }^{\circ} 15^{\prime} \mathrm{N} 78^{\circ} 07^{\prime} \mathrm{W}$ ] Julio 24 de 1995 [24 Jul. 1995] G. Andrade-C. Leg. Altitud: 1425 m. // GAC: 7615// ICN-MHN-L 14791 // ICN 011101 // (ICNO).

\section{Paratypes}

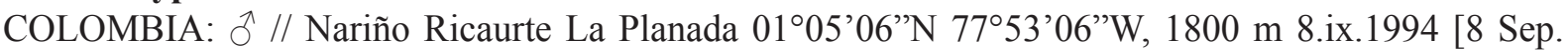
1994], Julian Salazar, Leg. SM-4385 // IAvH 8238 // genit JFL 336 // (IAvH); $q$ // Nariño La Planada Via Hondon $1^{\circ} 15^{\prime} \mathrm{N} 78^{\circ} 15^{\prime} \mathrm{W} 1930 \mathrm{~m}$ Malaise 16 x. 2.xi. 2000 [16 Oct.-2 Nov. 2000]. G. Oliva Leg. M. 139 // IAvH-E 67776 // genit JFL 337 // (IAvH).

\section{Other material examined}

Because so few specimens have been seen from the west of Colombia $(2 \hat{\jmath} \hat{\partial}, 1 \stackrel{q}{q})$ and Ecuador, $(1 \hat{\partial}, 2$ 우오) it is possible that, when more specimens are examined, the Ecuadorian population may prove to be a separate taxon. Therefore, the following specimens are not included in the type series:

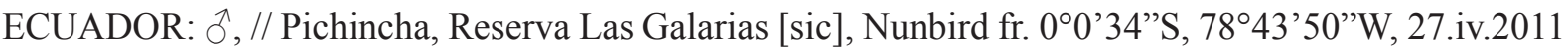
[27 Apr. 2011]/T Kell/\#008/FLMNH-MGCL-15-11-26/DNA Voucher lep-04376 (FLMNH); ㅇ, // Huigra, 1220 m, [2¹8’S 7859’W] Nov. 1926, Coxey // (ANSP); ㅇ, // Pichincha Prov., Santo Domingo de los Colorados, alt. 200 m, Apr. 1982 // (LACM).

A male labelled "EKWADOR [sic], Prov. Zamora-Chinchipe, Valladolid, 17051998 [17 May 1998], leg. K. Jasinski" (MZUJ), exhibits the white bridge on VFW, and the broader inner white stripe on VHW only extends as far as the larger of the lower ocelli, as in E. z. casagrande ssp. nov. Other features are consistent with the above diagnosis. Keith Willmott (pers. comm.) commented that the locality may be not reliable, and we suspect an inversion of labels with the E. z. greeneyi-like specimen, in the same collection, which bears a label from the western El Oro Province. 
In addition, we have seen a web image of a male at Tandayapa Lodge (1600 m, Nov. $28^{\text {th }} 2007$, W. Cook), and there is a picture of a male (presumably) in Silva (2011), taken at the Río Guajalito Reserve (1900 m, 12 Nov. 2009).

\section{Description}

\section{Male}

The FW length in the holotype is $58 \mathrm{~mm}$, in the paratype $62 \mathrm{~mm}$. The values of the P index are estimated at $5.5 \mathrm{~mm}$ in the holotype and $4.4 \mathrm{~mm}$ in the Ecuadorian specimen from Las Gralarias. These values are close to those observed in E. z. greeneyi; possibly, the HW projection should be more pronounced than in E. z. opimus. There is no R5-M1 orange mark on DFW; the orange DFW band is either moderate (HT; Fig. 5C) or well developed and composed of five spots of variable size which are just contiguous, being separated only by the veins; in that way, E. z. casagrande ssp. nov. may differ from E. z. greeneyi, where the spots are often separated. The iridescence is extremely faint. The androconial patch of the holotype is less lemon-coloured than in E. z. opimus (Fig. 5C); however, the paratype male and the single Ecuadorian male examined have a very pale cream androconial patch (Fig. 5D). The ground colour of the verso is lighter, more yellowish than in E. z. chachapoya ssp. nov. The isolated white spot in the VFW cell is quite large and semicircular. On the VFW, there is no white spot in the angle formed by the cubital vein and $\mathrm{Cu} 2$; the complete white connection between the white stripes in space $\mathrm{Cu} 2-2 \mathrm{~A}$ delimits half-a-circle (up against $\mathrm{Cu} 2$ ) with a chestnut-brown inner core and a dark brown outer ring (Fig. 5C). The narrow outer white stripe on the VHW only just extends down to the smaller of the lower ocelli; the broader inner white stripe only extends as far as the larger of the lower ocelli. The dark brown lines in the VHW cell and curved line above the $\mathrm{Cu} 1-\mathrm{Cu} 2$ ocellus are well developed; the distal lines form two conjoined elongate circles (Fig. 5C). The costal ocellus on the VHW has a narrow, offwhite outer ring; the black ring is almost complete. In the holotype, on the VHW, the largest diameter of Cu1-Cu2 ocellus measures $10.1 \mathrm{~mm}$ (cf. Table 5); it is weakly larger in the paratype; thus, there is no indication of a difference with either E. z. greeneyi or E. z. opimus. Genitalia are similar to those of E. z. greeneyi and other subspecies from the Northern Andes, while they strongly differ from the genitalia of E. z. chachapoya ssp. nov. (Fig. 13D-F).

Note. One striking feature of the male from Las Gralarias, Ecuador, is the circular orange spot with a large dark brown core in space M3-Cu1 of the dorsal forewing band (Fig. 5D). This is unique amongst all the E. zolvizora specimens examined. However, a smaller dark brown point is present in one male from the Río Aguacatal (eastern slope of the Colombian western cordillera), collected by Fassl (USNM), a male from "Cali" in MNHN (PBB 1406), and two males of E. z. chachapoya ssp. nov. from the upper Río Nieva (Amazonas, Peru) in MNHN (PBGL 471 and 518).

\section{Female}

The paratype female FWL is $62 \mathrm{~mm}$; Ecuadorian females range from 60 to $67 \mathrm{~mm}$. The ventral surface shows the same diagnostic features as the male. However, on VHW, the inner white stripe goes slightly beyond the ocelli, but remains shorter than in all other subspecies (Fig. 7D). The markings in the VHW cell of the Huigra female are rather faint, but this specimen is fairly old and worn (Fig. 7E). The dorsal branches of the inward projections of the sterigma are similar to those of E. z. greeneyi, as they have irregular outlines, but they are more distant from the internal side of the arch, as in E. z. chachapoya ssp. nov. and E. z. opimus (Fig. 15J).

\section{Flight period}

Specimens have been caught or seen in April, July, September, October and November. 


\section{Distribution}

Colombia. Nariño Department of south-west Colombia between 1380 and 1930 m.

Ecuador. E. z. casagrande ssp. nov. presumably extends in suitable habitat throughout the western slopes from the Colombian border to the extreme south of the country at heights of $1200 \mathrm{~m}$ to $1800 \mathrm{~m}$; the Santo Domingo specimen at $200 \mathrm{~m}$ is an anomaly and may be from a higher altitude along the road to Quito.

\section{Remarks}

Specimens of E. zolvizora from south-western Colombia and western Ecuador are characterized by a wide 'bridge' in space Cu2-2A on the VFW formed by a complete white connection between the white stripes, delimiting half-a-circle (up against $\mathrm{Cu} 2$ ) with a chestnut-brown inner core and a dark brown outer ring; in that way, E. z. casagrande ssp. nov. differs from its near neighbours E. z. opimus in the Cauca Valley, Colombia, and E. z. greeneyi in the Oriente of Ecuador, as well as from all other subspecies, except E. z. chachapoya ssp. nov., where we know 3 (of 35) specimens having a white bridge (MNHN: PBB 2310, PBGL 521 and PBGL 705). We consider that the presence of a wide, white bridge is the principal diagnostic character of $E$. $z$. casagrande ssp. nov., but suggesting a closer affinity with E. z. chachapoya ssp. nov. than E. z. greeneyi. However, the male genitalia are similar to those of E. z. greeneyi.

There are specimens of E. zolvizora collected in the $19^{\text {th }}$ and early $20^{\text {th }}$ century labelled from the western Ecuadorian village of 'Balzapamba'. Like many specimens supposedly from this locality, they are from eastern Ecuador and are in fact E. z. greeneyi.

Eryphanis zolvizora opimus Staudinger, 1887

Figs 5E-F, 7F, 13G-I, 15K

Eryphanis opimus Staudinger, 1887: 217.

Eryphanis zolvizora opimus - Stichel 1904: 33;1909: 157, fig. 36; 1932: 75. — Fruhstorfer 1912: 312. — D'Abrera 1987: 406-407. — Casagrande 2004: 203.

Eryphanis opimus (Staudinger, 1887) [sic] - Penz 2008: 15-15, figs 1I, 4I, 5I (status revised and redescription).

\section{Diagnosis}

HW projection only poorly developed; a faint orange spot between the R5-M1 veins is present in some specimens; the DFW band generally with five well developed, almost contiguous, crescent-shaped spots (Fig. 5E) (however, there are some specimens with small, sometimes blurred, disjunct spots; cf. Fig. $5 \mathrm{~F}$ ); on the VFW, in space Cu2-2A, the inner margin of the distal white stripe forms a projection that does not reach the black border of the proximal white stripe; in the VHW cell the dark brown lines and curved line above the $\mathrm{Cu} 1-\mathrm{Cu} 2$ ocellus are well developed (Fig. 5E-F). The valva axis has no swelling; the dorsal ridge has a row of more than 6 spines, dimimishing towards the extremity (Fig. 13G).

\section{Type material}

\section{Lectotype, here designated}

COLOMBIA: $\hat{O}$, dirty white, rectangular label: //Manizales, Cauca [handwritten in dark brown ink, followed by an indecipherable abbreviation: S?hl.]// (ZMHB).

\section{Paralectotype, here designated}

COLOMBIA: $\lambda^{\lambda}$, dirty white, rectangular label: //Manizales, Cauca [handwritten in dark brown ink, followed by an indecipherable abbreviation: S?hl.]// (ZMHB). 


\section{Type locality}

Manizales (Colombia).

\section{Description}

\section{Male}

The FWL varies from 58 to $66 \mathrm{~mm}$. Average $\mathrm{P}=3.9(\mathrm{n}=6$; cf. Table 3); it is possible that there is no significant difference with other populations from the Northern Andes, except E. z. greeneyi. In some specimens, there is a faint orange spot between the R5-M1 veins, making a very weak projection of the proximal branch of the submarginal band (Fig. 5E); this feature has not been observed in other specimens from the Northern Andes. The DFW band varies from well developed, with five barely contiguous spots, to five small disjunct spots in some specimens, that we consider to be individual variations, like similar specimens from northern Peru, Ecuador and Venezuela. The violet iridescence is a little more pronounced than that of E. z. greeneyi, but less than in E. z. reyi ssp. nov. and E. z. isabelae ssp. nov. (cf. Fig. 6). The androconial patch is a bright creamy, pale citrus yellow. The background colour of the ventral surface has a lighter yellowish aspect than in E. z. chachapoya ssp. nov. (Fig. 5E). On the VFW, the isolated white spot in the cell is medium to large, with a variable, roughly oval, triangular or crescent-like shape; there is sometimes a small white spot in the angle formed by the cubital vein and $\mathrm{Cu} 2$ (Fig. 5E-F); in space Cu2-2A, the inner margin of the distal white stripe forms a projection that does not reach the black border of the proximal white stripe, and is often less pronounced than in E. $z$. greeneyi (Fig. 5E-F). On the VHW, the white stripes extend far beyond the $\mathrm{Cu} 1-\mathrm{Cu} 2$ ocellus, notably the distal one, which reaches vein 2A; in the cell, the dark brown lines and curved line above the $\mathrm{Cu} 1-\mathrm{Cu} 2$ ocellus are well developed; the costal VHW ocellus has an incomplete pale circle, sometimes partially covered with white scales; the black ring is complete and sometimes thicker than in any other subspecies (Fig. 5E-F). The VHW Cu1-Cu2 ocellus ( $\Phi$ average value: $10.7 \mathrm{~mm} ; \mathrm{n}=6$; $\mathrm{cf}$. Table 5) is larger, on the average, than that of E. z. greeneyi and E. z. reyi ssp. nov., and much larger than in E. z. isabelae ssp. nov. Genitalia exhibit weak individual variations (Fig. 13G-I). The valva is regular, without a swelling; the ridge bears a row of more than 6 spines, the size of which varies more or less regularly; the gnathos is larger than those in E. z. zolvizora, and sometimes smaller than in E. z. chachapoya ssp. nov.

\section{Female}

Only 6 females are known (labelled from 'Calima Valley, Cauca River'; Calima, 45km W of Buga; Río Agua; 'Rio Aguatal'; Colombia Ost; and 'Colombie'). The FWL varies from 66 to $70 \mathrm{~mm}$. The diagnostic characters correspond to those of the males (Fig. 7F). On the dorsal surface, the FW band is composed of five narrow crescentic orange spots that just touch each other (the band is slightly narrower than that of most E. z. greeneyi females). There is the faintest hint of a sixth orange spot between the R5-M1 nerves (Fig. 7F). There is a strong purplish sheen in the middle of both the FW and HW. As in the male, on the VFW, in space Cu2-2A, the inner margin of the distal white stripe forms a projection that does not reach the black border of the proximal white stripe (an exception is the female from Río Aguacatal), unlike in E. z. reyi ssp. nov. and E. z. isabelae ssp. nov. The dorsal branches of the inward projections of the sterigma have a regular outline, in this way being different from E. z. greeneyi and more similar to E. z. chachapoya ssp. nov., but their extremities are notably less distant from the internal side of the arch than in females from northern Peru (Fig. 15K); nevertheless, the differences with one of the E. z. chachapoya ssp. nov. females (cf. Fig. 15H) are weak. Female genitalia of E. z. opimus do differ markedly from those of other Northern Andean females, except one female of E. z. reyi ssp. nov. which has thicker inward projections and shorter dorsal branches (cf. Fig. 15L).

\section{Flight periods}

The only ten dates that we have are from May to November. 


\section{Distribution}

Colombia. The only specimens with reliable data are from the Cauca Valley, and from Río Aguacatal (this name has often been misspelt on data labels as Aquatil, Aquatal, Aguatal, Aguaca, and similar), on eastern slopes of the western cordillera. It is unfortunate that, of the many specimens of E. z. opimus that we have seen, only five reliable localities can be confirmed in the Cauca Valley: Calima Valley, on the west side of the valley (i.e. east side of the western cordillera); and Armenia, Pereira, Manizales, and Mesopotamia, on the east side of the valley (i.e. west side of central cordillera). Fassl (1915a: 10) shows opimus on both sides of the western cordillera at heights between 2000 and $2500 \mathrm{~m}$, but we have not seen any E. zolvizora specimen from these altitudes on the west side of the western cordillera, although specimens labelled 'Cali, $1000 \mathrm{~m}$ ' in the MNHN and MPM were probably collected along the road from Cali to Buenaventura on the Pacific slope, as well as the 'Buenaventura-Queremal' male in the IAvH. Reliable altitudes range from 900 to $2500 \mathrm{~m}$.

\section{Remarks}

The taxon E. opimus was described by Staudinger (1887), on the basis of three syntypes (males), two from Manizales (Colombia) and one from Chanchamayo (Peru). After Stichel (1904), it was considered as a subspecies of E. zolvizora, until Penz (2008) revised its status. The name opimus has always been used for Colombian specimens (Stichel 1904, 1909, 1932; Fruhstorfer 1912; Fassl 1914, 1915a, 1915b; D'Abrera 1987). Staudinger noted differences between the Peruvian syntypic specimen and the Colombian ones. It should be noted that none of the syntypes match the figured specimen (fig. 36) in Stichel (1909). To stabilize the situation, we have designated as lectotype the undamaged Manizales syntype. The other Manizales specimen is therefore a paralectotype. As indicated previously, it is likely that the syntype from Chanchamayo belongs to E. z. chachapoya ssp. nov.

Eryphanis zolvizora reyi Bristow, Neild, De Sousa \& Huertas ssp. nov. Figs $6 \mathrm{~A}-\mathrm{B}, 8 \mathrm{~A}, 14 \mathrm{~A}-\mathrm{C}, 15 \mathrm{~L}$

\section{Diagnosis}

HW projection poorly developed; no orange mark between veins R5-M1 (Fig. 6A-B). The white spot near the middle of the VFW cell is relatively equidimensional, isolated, medium to large (Fig. 6A-B). On the VFW, the white vertical stripes in cell Cu2-2A are generally connected by a thin black horizontal line, thus distinguishing E. z. reyi ssp. nov. from E. z. opimus; the black ring of the anterior VHW ocellus is often broken at the costal margin (Fig. 6A). The valva is regular, without swelling; the ridge bears a row of more than 6 spines, the size of which varies more or less regularly (Fig. 14A).

\section{Etymology}

We name this subspecies to honour the memory of the Venezuelan Lepidopterist Rafael Fernando Rey Cárdenas (1958-2010). He was an adept field collector, with a special interest in butterflies of the family Pieridae. He placed great emphasis on collecting in the State of Táchira, around San Cristóbal, as well as in El Tamá National Park, where he discovered a remarkable new montane species of Catasticta $(C$. revancha - see Rey \& Pyrcz 1996). Fernando Rey also generously contributed to AN's research for the book series The Butterflies of Venezuela (Neild 1996; 2008). An obituary by one of the authors (AN) and Tomasz Pyrcz (MZUJ) is currently in preparation.

Type material (30 specimens)

\section{Holotype}

VENEZUELA: $\widehat{\jmath}$, two white labels printed in black: // VENEZUELA, Barinas, La Chimenea, 1500m, [849N 70³1’W]1-6-VI-1973 [1-6 Jun. 1973] // J. Salcedo col.// (MIZA). 


\section{Paratypes}

VENEZUELA: ^̊ , // Anzoategui, Qda Guazó, Venezuela, Lara, 1440 m, [9³6’'N 6953’W], 13-16 VI 72, [13-16 Jun. 1972] J. Salcedo \& F. Zambrano// (MIZA); ㅇ, // Anzoategui, Qda Guazó, Venezuela, Lara, 1440 m, [9³6’N 6953'W], 13-16 VI 72, [13-16 Jun. 1972] J. Salcedo \& F. Zambrano// (MIZA); đ, // Barinas, La Mina above San Isidro, 1450 m, [850’N 70³4’W], III-1988 [Mar. 1988], leg Romero // (AN); ô, // Barinas, San Isidro, Las Minas, 1475 m, [850’N 70³4’W], 07-SEP-2002 [7 Sep. 2002], Col. Juan C. de Sousa C. // (JCSC); đ̊, // Barinas, San Isidro, Las Minas, 1500 m, [850’N 70³4’W], 10 Oct.2010. Col. Mauro Costa // (JCSC); + , // Barinas, Qda. La Soledad, Via Barinitas - Sto. Domingo,

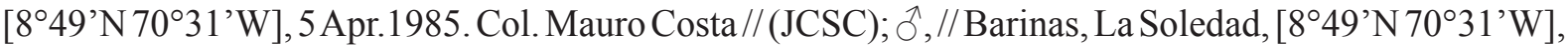
5-IV-1985 [5 Apr. 1985] // (MCC); đ̃, // Barinas, San Isidro, Mina, 1500 m. [850’N 70³4’W], 04-X2009 [4 Oct. 2009] // (MCC); Ò, // Barinas, San Isidro, Mina, 1500 m. [850’N 70³4’W], 04-X-2009 [4 Oct. 2009] // (MCC); ô, // Barinas, San Isidro, Mina, 1500 m. [850’N 70³4’W], 09-XI-2009 [9 Nov. 2009] // (MCC); đ̂, // Barinas, San Isidro, Mina, 1500 m. [850’N 70³4'W], 12-XII-2009 [12 Dec. 2009] // (MCC); ㅇ, // Barinas, San Isidro, Mina, 1500 m. [850’N 70³4’W], 05-I-2011 [5 Jan. 2011] (MCC); + , // VENEZUELA, Barinas, La Chimenea, 1500m, [849N 70³1’W]1-6-VI-1973 [1-6 Jun. 1973] // J. Salcedo col.// (MIZA); Oૈ, // Barinas, San Isidro, Vallée du Río Santo Domingo, 1500 m, [850’N 70³4’W], 9-XI-2010 [9 Nov. 2010], M. Costa \& S. Attal // (MNHN, PBB 2324); ô, // Barinas, San Isidro, Vallée du Río Santo Domingo, 1500 m, [850’N 70³4’W], 9-XI-2010 [9 Nov. 2010], M. Costa \& S. Attal // (MNHN, PBB 2325); Ō, // Barinas, Barinitas, [La Mina de San Isidro, $1450 \mathrm{~m}$, [850’N 70³4'W], X-87 [Oct. 1987], C.f.R // 115-JCSC // (R); + , // Barinas, Barinitas, [La Mina de

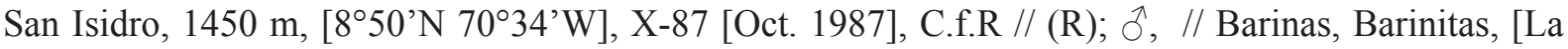
Mina de San Isidro, 1450 m, [850’N 70³4’W], X-87 [Oct. 1987], C.f.R // (R); + , // Barinas, Barinitas, [La Mina de San Isidro, 1450 m, [8 $8^{\circ} 50^{\prime} \mathrm{N} 70^{\circ} 34^{\prime} \mathrm{W}$ ], X-87 [Oct. 1987], C.f.R // (R); + , // Barinas, Barinitas, [La Mina de San Isidro, 1450 m, [850’N 70³4’W], X-88 [Oct. 1988], C.f.R // 116-JCSC // (R); + , // Barinas, Barinitas, [La Mina de San Isidro, 1450 m, [850’N 70³4’W], X-88 [Oct. 1988],

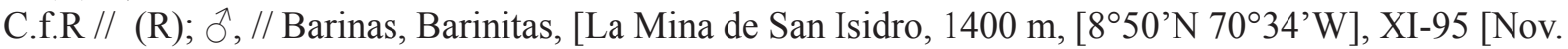
1995], C.f.R // (R); + , // Barinas, Barinitas, [La Mina de San Isidro, 1400 m, [850’N 70³4’W], XI-95 [Nov. 1995], C.f.R // (R); + , // Mérida, Páramo El Molino, SE of Sta Cruz de Mora, 1600 m, [8¹6’N 713ㄴ'W] 03.I.2001 [3 Jan. 2001], Leg. M. Costa // (AN); Ô, // Táchira, Sierra de El Tamá, Via Delicia, 1900 m, [7³6’N 72²6’W], III-87 [Mar. 1987] C.f.R // (R); O’, // Táchira, Sierra de El Tamá, Via Delicia (Pabellón), 1700 m, [7³6’N 72²6’W], IV-1990 [Apr. 1990] C.f.R // (R).

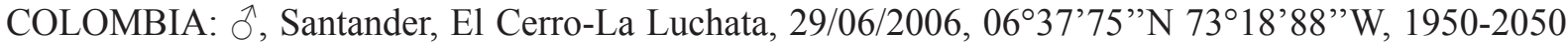
m, posada on vegetación bosque primero, B. Huertas, C. Rios y J. Arias leg., Proyecto YARE (IAvH); $\partial^{\lambda}$, as preceding specimen, but 30/06/2006; đ̂̃, Santander, Charalá, 2000 m, juillet 2008 (MNHN).

\section{Description}

Male

The FWL varies from 58 to $62 \mathrm{~mm}$, excluding one male from Colombia with an unusually small FWL of $52 \mathrm{~mm}$ (which has been excluded from our statistical measurements). The holotype FWL is $59.5 \mathrm{~mm}$. The hindwing projection (average $\mathrm{P}=3.6 ; \mathrm{n}=15$; cf. Table 3 ) is rather similar to that of E. z. zolvizora and E. z. opimus. There is no orange mark between veins R5-M1 (Fig. 6A-B). The holotype and some of the paratypes have five submarginal orange spots which are contiguous at the veins (Fig. 6A-B). However, the form and size of these spots are variable and in some specimens they are indistinct and disjunct. The violet iridescence on the dorsal surface is stronger than in E. z. opimus, but it is usually a little weaker than in E. z. isabelae ssp. nov., especially on the DFW (Fig. 6A-B). The bright creamy, pale citrus androconial patch is shorter, on average, than in E. z. opimus and E. z. isabelae ssp. nov. (cf. Table 4); it should be noted that, in one specimen from the Sierra de El Tamá, the colour of the patch is a pale greyish-brown, as in E. z. isabelae ssp. nov. Ground colour of the ventral surface as in other subspecies of the Northern Andes, except some darker specimens of E. z. greeneyi (Fig. 6A-B). The shape of the 
isolated white spot near the middle of the VFW cell is irregular but relatively equidimensional, and its size varies from medium to large; in this way, E. z. reyi ssp. nov. (Fig. 6A-B) is clearly different from E. z. isabelae ssp. nov. (Fig. 6C-D) and other subspecies. On the VFW, the white spot at the basal angle of cell $\mathrm{Cu} 1-\mathrm{Cu} 2$ is generally very small (Fig. 6A), or absent (Fig. 6B). On the VFW, the white vertical stripes in cell $\mathrm{Cu} 2-2 \mathrm{~A}$ are generally connected by a thin black horizontal line (Fig. 6A-B), which immediately distinguishes $E$. z. reyi ssp. nov. from E. z. opimus, in which this bridge is absent. On the VHW, the white stripes extend far posterior to the $\mathrm{Cu} 1-\mathrm{Cu} 2$ ocellus. On the VHW, the black markings in the cell and the curved line anterior to the $\mathrm{Cu} 1-\mathrm{Cu} 2$ ocellus are fainter than in E. z. opimus (Fig. 6A-B). In most specimens, the anterior HWV ocellus is encircled by an outer pale/off white circle, contrasting with the background more than in E. z. opimus; in addition, the black ring is often broken at the costal margin (Fig. 6A), a difference with E. z. opimus and E. z. isabelae ssp. nov. On average, the VHW Cu1-Cu2 ocellus ( $\Phi$ average value: $9.5 \mathrm{~mm} ; \mathrm{n}=15$; cf. Table 5) is probably a little smaller than in E. z. opimus. The valva is similar to those of other subspecies of the Northern Andes (Fig. 14A-C); the gnathos is clearly smaller than in E. z. chachapoya ssp. nov. and generally slightly smaller than in E. z. opimus.

\section{Female}

Female FWL length varies from 63 to $66.5 \mathrm{~mm}$ (mean $=64.8 \mathrm{~mm} ; \mathrm{n}=8)$. The principal diagnostic characters are the same as in males (Fig. 8A). On the VFW, the black line at the base of VFW cell M3$\mathrm{Cu} 1$ is well-defined, while it is absent or nearly so in females of E. z. isabelae ssp. nov. The forewing band is composed of five well developed, crescentic, submarginal orange spots which are contiguous at the veins. There is a violet-blue dorsal iridescence on both the FW and HW, almost similar to that of E. z. opimus, but usually not so extensive or as blue as that of E. $z$. isabelae ssp. nov. The genitalia of the two females we have dissected exhibit some differences. In one specimen (El Molino, Mérida), the sterigma is close to that of the females of E. z. opimus and E. z. casagrande ssp. nov., as well those of $E$. z. isabelae ssp. nov. females: the inward projections are short and not very wide, and the dorsal branches are large. In the other specimen (Barinitas, Barinas; Fig. 15L), the inward projections are wider and larger; consequently the dorsal branches are shorter; most likely this is a matter of individual variation.

\section{Flight periods}

Dated specimens are for March to June, and September to November.

\section{Distribution}

Colombia. Santander Province of northern Colombia at almost $2000 \mathrm{~m}$.

Venezuela. Cordillera de Mérida in north-western Venezuela, from approximately 1400 to $1900 \mathrm{~m}$ on either side of the Cordillera.

\section{Remarks}

Specimens of this taxon were discovered during an expedition by the MIZA in 1972 to the Cordillera de Mérida, in north-western Venezuela, where a series of males and females were collected. More recently, E. z. reyi ssp. nov. was observed at sunny intervals resting on herbaceous vegetation, by one of the authors $(\mathrm{BH})$ and colleagues in the pristine forest (surrounded by regenerated forest) at La Luchata, in the Serranía de los Yariguíes, Santander, during field expeditions of the YARE Project, and 2 specimens were collected (see details in Huertas \& Donegan 2006). La Luchata is the type locality of another recently described butterfly (Huertas et al. 2009). 
Eryphanis zolvizora isabelae Neild \& De Sousa ssp. nov.

Figs 6C-D, 8B, 14D-F, 15M-O

\section{Diagnosis}

HW projection moderately developed. No orange mark between veins R5-M1. The androconial patch is on average longer (mean: $9 \mathrm{~mm}$ ) than in all other subspecies and is pale greyish-brown (Fig. 6C-D). The violet iridescence on the $\mathrm{FW}$ is generally slightly stronger and distally more extensive than in $E$. z. reyi ssp. nov. The white patch in the VFW cell next to the base of $\mathrm{Cu} 1-\mathrm{Cu} 2$ is larger by $50 \%-100 \%$ than other subspecies (Fig. 6C-D). On the VFW, the white Cu2-Cu1 spot in the basalmost angle formed by the cubital vein and $\mathrm{Cu} 2$ is relatively large and always present (Fig. 6C-D). On the VFW, the black line at the base of cell M3-Cu1 is usually diffuse or poorly-defined in males (Fig. 6C-D), and diffuse or nearly absent in females (Fig. 8B), a difference with all other subspecies. The valva is regular, without swelling; the ridge bears a row of more than 6 spines, the size of which varies more or less regularly.

\section{Etymology}

We name this subspecies in honour of the memory of Isabel Montesino de Romero (1931-2008). The Romero family collected the vast majority of the type series of both the Venezuelan subspecies described herein. The late Isabel, and her children Francisco ("Paco") and María de la Concepción ("Conchita"), very kindly helped us in many ways during our protracted research for this paper, and we use this opportunity to thank them profusely for their great kindness and generosity.

Type material (12 specimens)

\section{Holotype}

VENEZUELA: $\widehat{\jmath}$, white label handwritten in black ink: // Choroní, 1450. [Vía Choroní $1450 \mathrm{~m}$ ] [10²1'N 67³4'W] II-78 [Feb. 1978]. C. f. R. s. [collected by familia Romero] // (R, to be donated to MIZA).

\section{Paratypes}

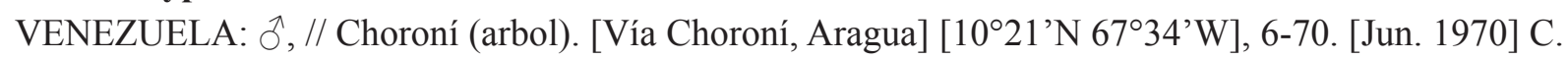
f. R. // 111-JCSC // (R); đ̂, // Choroní. 1450. [Vía Choroní, Aragua, 1450 m] [10²1’N 67³4’W], 9-71. [Sep. 1971] C. flia. Romero // 117-JCSC // (MIZA); Oૈ, // Choroní 15. [Vía Choroní, Aragua] [10²2’N 67³5’W], 10-72. [Oct. 1972] C. f. R. // 112-JCSC // (R); đo, // Choroní, 1250. [Vía Choroní, Aragua,

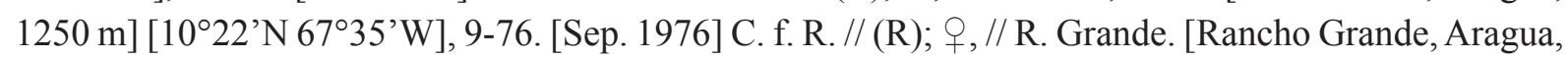
$1150 \mathrm{~m}$ ] [10²0’N 6740’W], 8-65. [Aug. 1965] C. Eduardo // 118-JCSC // (MIZA); q, // [Choroní 21. [Vía Choroní, Aragua] [10²1’N 67³4’W], 8-70. [Aug. 1970] C. f. R. 1550 m. // 113-JCSC // (R); + , // Choroní. 1.400 s. [Vía Choroní, Aragua, 1400 m] [10²2’N 67³5’W], V-79.[May 1979] C. f. R. // (R); †, // Choroní 28. [Vía Choroní, Aragua] [10²2’N 67³5’W], 28-9-76. [28 Sep. 1976] C. f. R. 1150 m. Cara Norte // 114-JCSC // (R);, , //La Llanada. 1.650 mts. [Parque Nacional el Avila, Distrito Federal] [10³3'N 66 56'W], 29 Oct. 1989 // (MNHN, PBB 2322); ㅇ, // Colonia Tovar. 2.100 mts. [10²4'N 67¹9'W], IV-93. [Apr. 1993] C. F. R. Edo. Aragua // (R); ㅇ, // Col. Tovar, 2.100 m, via Capachal.

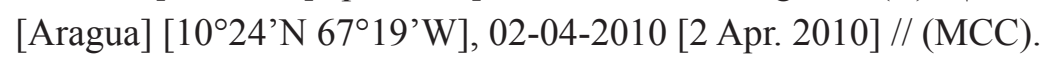

\section{Other material examined}

Included in the measurements but excluded from the type series: 0 , // Mexico // Druce Coll. ex Kaden Coll. // Eryphanis zolvizora Hew. Godman-Salvin Coll. 1919.-6. // BMNH (E) \#808093 // (BMNH). 


\section{Description}

Male

The FWL varies from 57 to $66 \mathrm{~mm}$ (mean: $63.3 \mathrm{~mm}$; $=6$ ). The holotype FWL is $60 \mathrm{~mm}$. The hindwing projection is developed to an average degree $(\mathrm{P}=4.1 ; \mathrm{n}=5$; cf. Table 3$)$, similar to specimens from Colombia. There is no orange mark between veins R5-M1 (Fig. 6C-D). The holotype (Fig. 6C) and some of the paratypes have five submarginal orange spots which meet at the veins (but these are separated from each other by the vein itself, which is dark brown); however, although the form and size of these spots are variable, they are well-developed in all but one of the known specimens; therefore, it is likely that this character falls into the variation observed in populations from the Northern Andes and northern Peru. The violet iridescence on the DFW is generally slightly stronger and distally more extensive than in E. z. reyi ssp. nov. and E. z. opimus. The length of the DHW androconial patch is on average longer than in all other subspecies, with a mean of $9.0 \mathrm{~mm}(\mathrm{n}=6$; $\mathrm{cf}$. Table 4$)$, and the patch is pale greyish-brown (Fig. 6C-D), while it is a bright creamy white in all other subspecies, except in some rare individuals. Ground colour of the ventral surface as in other subspecies of the Northern Andes (except some darker specimens in E. z. greeneyi). The white patch on the FWV cell next to the base of $\mathrm{Cu} 1-\mathrm{Cu} 2$ is roughly subtriangular or in the form of an inverted heart-shape; it is distinctly larger (50\%-100\%) than in any other subspecies (Fig. 6C-D). On the VFW, the white $\mathrm{Cu} 2-\mathrm{Cu} 1$ spot in the basalmost angle formed by the cubital vein and $\mathrm{Cu} 2$ is relatively large and always present (Fig. 6C-D). On the VFW, the black line at the base of cell M3-Cu1 is usually diffuse or poorly defined in males (it is narrow, but well defined, in all other subspecies). On the VFW, the white vertical stripes in cell $\mathrm{Cu} 2-2 \mathrm{~A}$ are generally connected by a thin black horizontal line (Fig. 6C-D). On the VHW, the black designs in the cell and the curved line anterior to the $\mathrm{Cu} 1-\mathrm{Cu} 2$ ocellus are fainter than in E. z. opimus, but almost similar to those of $E$. z. reyi ssp. nov. In most specimens, the anterior VHW ocellus is encircled by an outer pale/ off-white circle, contrasting with the background more than in E. z. opimus; the black ring is complete (Fig. 6C-D), being dissimilar to E. z. reyi ssp. nov. in which it is usually broken at the costal margin. On average, the VHW Cu1-Cu2 ocellus ( $\Phi$ average value: $8.7 \mathrm{~mm} ; \mathrm{n}=5$; cf. Table 5) is probably similar to that of $E$. $z$. reyi ssp. nov. and perhaps of E. z. greeneyi, but smaller than in all other subspecies. The valva is regular, without swelling; the ridge bears a row of more than 6 spines, the size of which varies more or less regularly (Fig. 14D-F); the gnathos is generally slightly smaller than in E. z. opimus; there is no noticeable difference with $E$. z. reyi ssp. nov.

\section{Female}

Female FWL length varies from $63 \mathrm{~mm}$ to $68.5 \mathrm{~mm}(\mathrm{n}=6)$. The dorsal and ventral surfaces show the same diagnostic features as in the male. The violet-blue dorsal iridescence on both the FW and HW is usually a more extensive, lighter and bluer tint than the one observed on E. z. reyi ssp. nov. (Fig. 8B). The inward projections of the sterigma are narrower than in E. z. opimus and E. z. reyi ssp. nov. and the bases of the dorsal branches are widely separated from the internal side of the arch (Fig. 15M-O); nevertheless, the extremities of these branches are close to it and clearly cross in 3 of the 4 dissected specimens; in this way, E. z. isabelae ssp. nov. possibly differs from other subspecies.

\section{Flight periods}

Specimens have been collected in February, April, May, and June, but the majority were taken in August, September and October. With the exception of February, which is usually (but not always!) dry, these months fall within the rainy season.

\section{Distribution}

Venezuela. This taxon appears to be endemic to the Cordillera de la Costa in northern Venezuela, where it has been recorded from approximately $1150 \mathrm{~m}$ to at least $2100 \mathrm{~m}$. 


\section{General Discussion}

Together with ornithologists, lepidopterists contributed to the 'Trinomial Revolution' in Zoology, 'subspecies' being acknowledged as an official nomenclatural rank (Mallet 2007). However, even in birds, which are far better known than any other major taxon, species concepts and limits are the subject of continual debate (Cracraft 2000; Alström et al. 2008; James 2010). There is no consensus in ornithology on how to treat subspecies, with some authorities preferring phylogenetic concepts and the elimination of many subspecies altogether (e.g. Zink 2004) and others noting the importance of this status (e.g. Patten \& Unitt 2002; Remsen 2010). Subspecies have been defined as "a breeding population that occupies a distinct segment of the geographic range of its species and that is measurably distinct in phenotype, genotype, or both" (James 2010). The most frequent modern usage for subspecies in ornithology is for diagnosable allopatric populations with small non-clinal differences from other allopatric populations, but where the differences are not considered equivalent to those between sympatric species (Remsen 2010). This concept generally corresponds to the practice of delimiting subspecies among lepidopterists.

Despite this, many entities have been described as subspecies for geographical forms recognizable only to their author (Descimon \& Mallet 2009), thus cluttering checklists and contributing to taxonomic inflation. Descimon \& Mallet (2009), arguing for a revival of the subspecies rank in a modern way, emphasized 'cohabitation' as the 'touchstone' of all criteria for species separation: when overlapping distinct populations produce unimodal frequency distributions of morphological traits and genotypes, subspecies should be designated, while separate species must be recognized if frequency distributions are bimodal. However, the cohabitation criterion is efficient only if overlapping populations can be accurately sampled.

The Eryphanis zolvizora group offers a case study of these issues. Our study represents the most comprehensive survey of this group ever accomplished. Specimens have been collected over a period of more than 150 years, in a relatively small number of localities scattered along the Andes. Even in northern Peru, where a special effort has been made recently, only 20 males and 6 females were obtained from 2005 to 2012: E. zolvizora butterflies are obviously uncommon in the field. Despite this limited information, we have decided to recognize eight taxa distributed from Bolivia to Venezuela (Fig. 16).

Having studied a large number of male genitalia, we observed individual variation between right and left valvae, and individual variation of valvae and gnathi. However, these limited variations do not blur the existence of distinctive genitalia structures corresponding to geographical groups of populations. Within the genus Eryphanis, male genitalia present strong differences between several previously described species, as illustrated by Penz (2008). Therefore, considering the differences in male genitalia between E. zolvizora zolzivora and E. z. inca ssp. nov.; E. z. inca ssp. nov. and E. z. chachapoya ssp. nov.; and E. z. chachapoya ssp. nov. and E. z. greeneyi, it would have been logical to acknowledge that these taxa correspond to different species. However, we considered here the eight taxa of the Eryphanis zolvizora group as subspecies, for two reasons. First, limits between taxa indicated by male genitalia characters and by wing characters do not always coincide. Second, in the present state of knowledge, there are no known contact zones between any E. zolvizora taxa; therefore, there is no information relevant to assessing the cohabitation criterion.

Thus, we have preferred to adopt a lumper's attitude, assuming that clear differences in male genitalia do not necessarily imply separate species. It should be emphasized that such differences exist within taxa from the Central Andes (Bolivia and Peru), while there is no significant difference between taxa from the Northern Andes (Ecuador, Colombia, Venezuela). Therefore, if male genitalia differences support species separation, Central Andean taxa are better candidates for species rank than Northern Andean taxa. For example, data suggest that E. z. inca ssp. nov. and E. z. chachapoya ssp. nov. perhaps overlap in central Peru. If their cohabitation were demonstrated, it is possible that the distribution of 


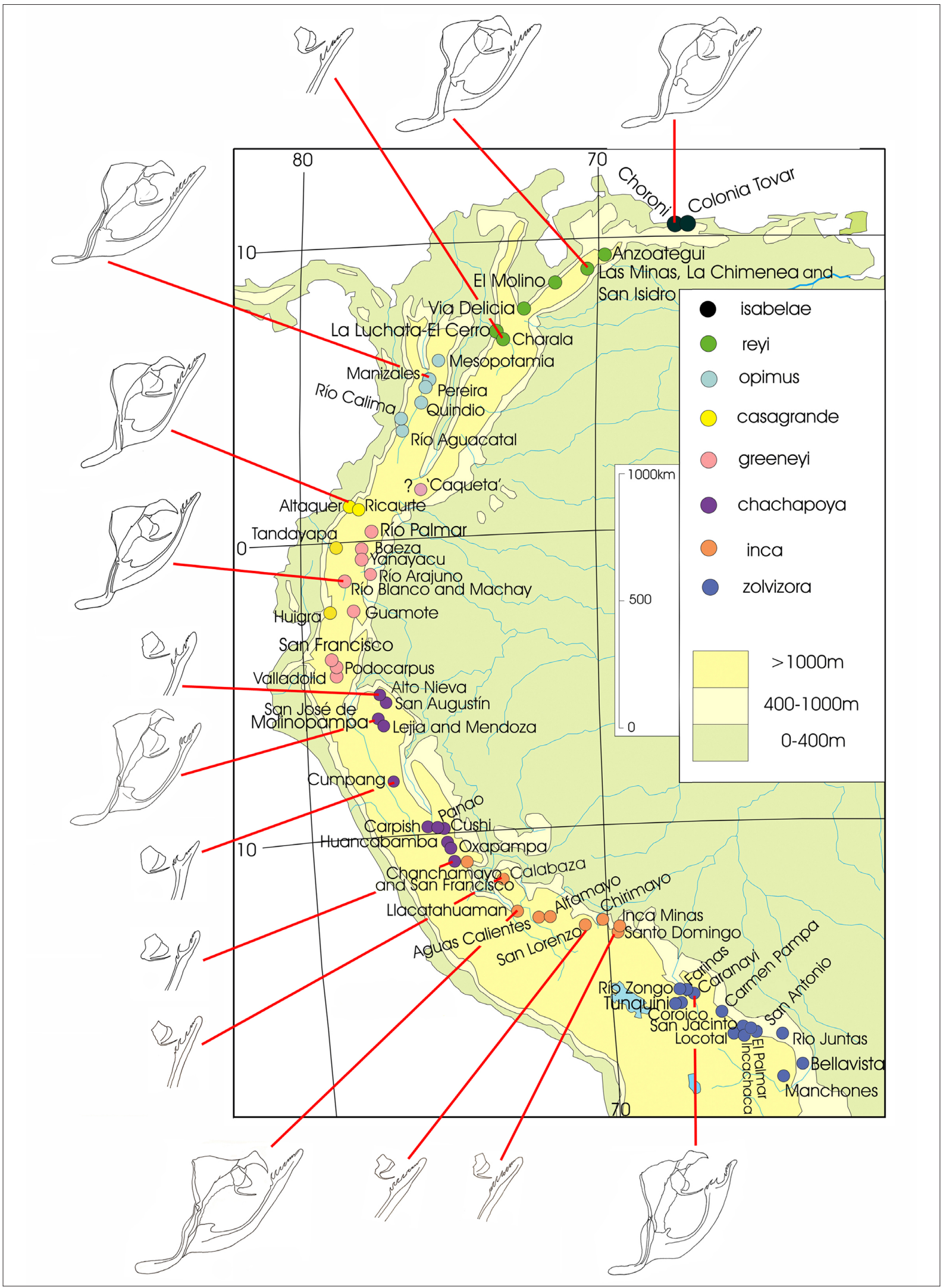

Fig. 16. Geographical distribution of Eryphanis zolvizora subspecies. Unreliable localities are excluded. Male genitalia of specimens illustrating the different subspecies are represented. 
their morphological characters would be bimodal, supporting the existence of two species (Descimon \& Mallet 2009). Similarly, geographical information would be necessary to check the spatial relationships between E. z. zolvizora and E. z. inca ssp. nov.: if cohabitation with bimodal distributions of characters were revealed, two species should be recognized. Moreover, the precise geographical relationships between E. z. chachapoya ssp. nov. and the Ecuadorian subspecies E. z. greeneyi and E. z. casagrande ssp. nov. must be studied from northern Peru to the western and eastern Andean slopes of southern Ecuador. As male genitalia of E. z. chachapoya ssp. nov. differ from those of the Ecuadorian subspecies, the cohabitation of populations with a bimodal distribution of characters is a plausible hypothesis.

Between subspecies from the Northern Andes, differences concern several subtle wing characters that often have only a 'statistical value'. However, we decided to create three new taxa to emphasize plausible evolutionary divergences between populations associated with different geographical areas. In so doing, we implicitly apply the phylogenetic concept. Should someone decide to raise these taxa to species rank, this decision will contribute to taxonomic inflation, as defined by Isaac et al. (2004) "for cases in which many existing subspecies are raised to species level".

Taxonomic inflation has important influences on conservation (Agapow et al. 2004; Isaac et al. 2004; Mallet 2007). Species are the 'currency' for conservation policies, which generally consider species richness, number of endemic species and number of endangered species in order to choose and manage conservation areas. When a polytypic species is split into several species, these species evidently have more restricted geographic ranges and decreased abundance. Thus, the number of endemic and fragile species increases. However, the primary source of taxonomic inflation is the creation of new taxa belonging to the 'species-group' in the sense of the International Code of Zoological Nomenclature (art. 45.1), whatever may be the level initially chosen - either species or subspecies. As emphasized by Mallet (2007), conservationists are increasingly aware of the conservation of biodiversity at all hierarchical levels, "including well-marked subspecies". Thus, from a pragmatic viewpoint, any taxon described as a 'species-group entity' should have the same potential interest. As a consequence, the taxonomist's first responsibility is to decide whether specimens from a particular area can be named: in so doing, he creates a 'potential conservation entity'. As underlined by Agapow et al. (2004), to use measures other than species counts, for example subspecies counts, "forces us to ask what it is that we are trying to preserve".

The Eryphanis zolvizora group is endemic to the Tropical Andes, the world's richest Biodiversity Hotspot (Mittermeier et al. 2004). This hotspot encompasses a very fragmented geographical system of cordilleras and valleys, resulting from a complex geodynamic history, which certainly influenced the diversification of butterflies (Blandin \& Purser 2013). Cloud forests form an ecological belt which could develop only when mountain ranges attained sufficient altitudes. For example, such altitudes were probably attained far longer than 10 million years ago in Bolivia (Barnes \& Ehlers 2009), while the Colombian eastern cordillera only attained 1500-2000 m a.s.l. by between 5 and 2 million years ago (Gregory-Wodzicki 2000). Therefore, it is possible that cloud forest butterfly lineages, from one range to another, have different ages. In this context, it seems logical that the level of morphological divergence between E. zolvizora populations may differ, depending on whether they inhabit old or recent ranges. Thus, by recognizing within the Eryphanis zolvizora group subspecies with different levels of morphological divergence, we underline the evolutionary heterogeneity of the Tropical Andes Hotspot, and the interest to preserve cloud forests not only at the core of each entity's area, but also in transition areas where evolutionary hypotheses could be checked.

\section{Acknowledgements}

Part of this work was realized in the framework of the project "Géographie de la Biodiversité des Lépidoptères dans le nord du Pérou", which received financial support from the Muséum national 
d'Histoire naturelle (Paris) for several years from 2005 (Programme Pluri-Formations "Etat et structure phylogénétique de la biodiversité actuelle et fossile"). Field work was performed with permission of Peruvian authorities. We warmly thank Dr. G. Lamas (MJP, Lima), for access to collections, loan of specimens, information and comments, and G. Lachaume (Paris) for collaboration in the field and for many stimulating discussions.

The YARÉ expeditions in Colombia were supported by: the Royal Geographical Society, BP Conservation Programme (BirdLife International, Conservation International, Flora \& Fauna International, Wildlife Conservation Society), Fondo para Acción Ambiental, Fundación Omacha, Conservation International Colombia (Becas Iniciativa de Especies Amenazadas - Jorge Ignacio ‘El Mono' Hernández-Camacho), Rio Tinto plc, Duke of Edinburgh, the Percy Sladen Memorial Fund (Linnean Society), Fundación ProAves, Game Conservancy Trust, World Pheasant Association, Tropical Andean Butterflies Diversity Project, Carter Ecological, Universidad Industrial de Santander, Universidad de Caldas, Universidad de Tolima and Gobernación de Santander. Special thanks to J.J Arias and C. Rios.

Ackowledgements are due to the Muséum national d'Histoire naturelle (Paris) and the Natural History Museum (London) for letting us facilities there such as collections, labs and librairies, and to the Biodiversity Library for facilitating access to key research resources.

The authors acknowledge the invaluable help from each of the following collection owners and curators, and colleagues, for providing access to the collections and specimens, loan of specimens, authorization for taking photographs, and for assisting with information, photographs or drawings, or help in the field:

G. Andrade (Colombia, Bogotá, ICNUN). - S. Attal (France, Paris). - H. Azurduy, L. Gonzales and T. Vidaurre (Bolivia, Natura Fundation, Santa Cruz). - M.M. Casagrande (Brasil, UFPR, Curitiba). - J. Clavijo and J. DeMarmels (Venezuela, Maracay, MIZA). - M. and C. Costa (Venezuela, Caracas). - R. de Vos (The Netherlands, Amsterdam, ZMA). - P. Grootaert (Belgium, Brussels, IRSN). - J. Hogan (United Kingdom, Oxford, UMO). - J.-F. Le Crom (Bogotá). - J. Ledezma and A.Valdivia (Bolivia, Santa Cruz de la Sierra, MHNNKM). - C. Medina and A. Parrales (Colombia, Bogotá, IAvH). - W. Mey (Germany, Berlin, ZMHB). - H. Morgenroth (United Kingdom, Exeter, RAMM). - C. Penz (USA, University of New Orleans). - Padre F. Piñas (Ecuador, Quito). - T. Pyrcz (Poland, Krakow, MZUJ). - R.G. Robbins and B. Harris (USA, Washington D.C., USNM). - F. and C. Romero (Venezuela, Maracay). - J. Salazar (Colombia, Manizales). - Jaime Sarmiento (Bolivia, La Paz, CBF). - X. Silva (Ecuador, Quito). - P. Thompson (United Kingdom, Coventry, HAGAM). - B. van Bekkum-Ansari (The Netherlands, Leiden, Naturalis). - J. Weintraub (USA, Philadelphia, ANSP). - Keith Willmott (USA, Gainesville, FLMNH). - P. Wilson (United Kingdom, Cornwall). - W. Xie (USA, Los Angeles, LACM).

The authors also thank two anonymous referees for their useful comments and suggestions.

\section{References}

Agapow P-M., Bininda-Edmonds O.R.P., Crandall K.A., Gittleman J.L., Mace G.M., Marshall J.C. \& Purvis A. 2004. The impact of species concept on biodiversity studies. The Quaterly Review of Biology 79: 161-179. http://dx.doi.org/10.1086/383542

Alström P., Rasmussen P.C., Olsson U. \& Sundberg P. 2008. Species delimitation based on multiple criteria: the Spotted Bush Warbler Bradypterus thoracicus complex (Aves: Megaluridae). Zoological Journal of the Linnean Society 154: 291-307. http://dx.doi.org/10.1111/j.1096-3642.2008.00418.x

Barnes J.B. \& Ehlers T.A. 2009. End member modes for Andean Plateau Uplift. Earth Science Reviews 97: 117-144. http://dx.doi.org/10.1016/j.earscirev.2009.08.003 
Berlepsch H.G. von 1901. Mitteilungen über die von den Gebrüdern G. und O. Garlepp in Bolivia gesammelten Vogel und Beschreibungen neuer Arten. Journal für Ornithologie 49: 81-99.

Blandin P. 1977. La distribution géographique des Brassolinae (Lepidoptera-Satyridae). Faits et problèmes. In: Descimon H. (ed.) Biogéographie et évolution en Amérique tropicale: 161-218. Publications du Laboratoire de Zoologie de l'Ecole Normale Supérieure, Paris.

Blandin P. \& Descimon H. 1975. Contribution à la connaissance des lépidoptères de l'Equateur. Les Brassolinae (Nymphalidae). Annales de la Société entomologique de France (N.S.) 13: 3-28.

Blandin P. \& Descimon H. 1977. Contribution à la connaissance des lépidoptères de l'Equateur. Nouvelles données sur les Brassolinae (Nymphalidae) de l'Occidente. Annales de la Société entomologique de France (N.S.) 13: 75-88.

Blandin P. \& Purser B. 2013. Evolution and diversification of Neotropical butterflies: Insights from the biogeography and phylogeny of the genus Morpho Fabricius, 1807 (Nymphalidae: Morphinae), with a review of the geodynamics of South America. Tropical Lepidoptera Research, 23(2): 62-85.

Brack Egg A. \& Mendiola Vargas C. 2004. Ecología del Perú. Asociación Editorial Bruño, Lima.

Brown A.D. \& Kappelle M. 2001. Introducción a los bosques nublados del neotrópico: una síntesis regional. In: Kappelle M. \& Brown A.D. (eds) Bosques nublados del neotrópico: 27-40. Instituto Nacional de Biodiversidad, Costa Rica.

Campos F. 1927. Catálogo preliminar de los lepidópteros del Ecuador. Primera parte. Ropalóceros. Revista del Colegio Nacional Vicente Rocafuerte (Guayaquil) 9: 3-106.

Casagrande M.M. 2004. Tribe Brassolini. In: Lamas G. (ed.) Checklist. Part 4A. HesperioideaPapilionoidea. Atlas of Neotropical Lepidoptera vol. 5A: 201-205. Association of Tropical Lepidoptera/ Scientific Publishers, Gainesville.

Cracraft J. 2000. Species concepts in theoretical and applied Biology: A systematic debate with consequences. In: Wheeler Q.D. \& Miller R. (eds) Species Concepts and Phylogenetic Theory: A Debate: 1-14. Columbia University Press, New York.

D’Abrera B. 1987. Butterflies of the Neotropical Region. Part III. Brassolidae, Acraeidae, \& Nymphalidae (Partim). Hill House, Victoria.

Descimon H. \& Mallet J. 2009. Bad species. In: Settele J., Shreeve T., Konvicka M. \& Van Dyck H. (eds) Ecology of Butterflies in Europe: 219-249. Cambridge University Press, Cambridge.

Dognin P. 1894. Lépidoptères de Loja et environs (Equateur). Descriptions d'espèces nouvelles. Troisième livraison. Imprimerie F. Levé, Paris.

Fassl A.H. 1911. Tropische Reisen. III. Erforschung des Monte Tolima. Entomologische Zeitschrift 24: 250-252, 259-260, 263-264, 267-268.

Fassl A.H. 1914. Tropische Reisen. V. Das obere Caucatal und die Westcordillere. Entomologische Rundschau 31: (7) 35-38, (38) 42-46, (39) 50-52, (10) 57-58.

Fassl A.H. 1915a. Die vertikale Verbreitung der Lepidopteren in der Columbishcen West-Cordillere. Entomologische Rundschau 32: 9-12.

Fassl A.H. 1915b. Tropische Reisen. VII. Ost-Columbien und die Llanos. Entomologische Rundschau 32: 33-35.

Fassl A.H. 1920. Meine Bolivia-Reise. Entomologische Rundschau 37: 10-11, 15-16, 17-18, 22-23, 25 27, 29-30, 34-35, 41-43, 45-48. 
Fruhstorfer H. 1912. 5. Familie Brassolidae. In: Seitz A. (ed.) Die Gross-Schmetterlinge der Erde 5: 285-332. Alfred Kernen Verlag, Stuttgart.

Gregory-Wodzicki K.M. 2000. Uplift history of the Central and Northern Andes: A review. GSA Bulletin 112: 1091-1105. http://dx.doi.org/10.1130/0016-7606(2000)112<1091:UHOTCA $>2.0 . C O ; 2$

Griffin F.J. 1932. An attempt to determine the true dates of publication of Hewitson (W.C.) Illustr. New spec. exot. Butterflies, 5 vols. [1852-] (1856) 1876. Novitates Zoologicae, a Journal of Zoology in connection with Tring Museum, Tring 37(2): 189-206.

Hemming A.F. 1967. The generic names of the butterflies and their type-species (Lepidoptera: Rhopalocera). Bulletin of the British Museum of Natural History (Entomology), Supplement 9: 1-509.

Huertas B.C. \& Donegan T.M. (eds) 2006. Proyecto YARÉ: investigación y evaluación de las especies amenazadas de la Serranía de los Yariguíes, Santander, Colombia. Informe final. Colombian EBA Project Rep. Ser. 7. Available from http://www.proaves.org [accessed 29 Oct. 2013]

Huertas B., Rios C. \& Le Crom J.F. 2009. A new species of Splendeuptychia from the Magdalena Valley in Colombia (Lepidoptera: Nymphalidae: Satyrinae). Zootaxa 2014: 51-58.

Isaac N.J.B., Mallet J. \& Mace G.M. 2004. Taxonomic inflation: its influence on macroecology and conservation. Trends in Ecology and Evolution 19: 464-469. http://dx.doi.org/10.1016/j.tree.2004.06.004

James F.C. 2010. Avian subspecies: Introduction. Ornithological Monographs 67: 1-5. http://dx.doi. org/10.1525/om.2010.67.1.1

Kirby W.F. 1877. A Synonymic Catalogue of Diurnal Lepidoptera. Supplement. John Van Voorst, London.

Kirby W.F. 1879. Catalogue of the collection of diurnal Lepidoptera formed by the late William Chapman Hewitson of Oatlands, Walton-on-Thames; and bequeathed by him to the British Museum. John Van Voorst, London.

Lamas G. 1981. Introducción a la Historia de la Entomología en el Perú. II. Período de los viajeros, colectores y estudiosos especializados. Revista peruana de Entomología 23: 25-37.

Lamas G., Robbins R.G. \& Field W.D. 1995. Bibliography of Butterflies. An Annotated Bibliography of the Neotropical Butterflies and Skippers (Lepidoptera: Papilionoidea and Hesperioidea). Atlas of Neotropical Lepidoptera, Vol. 124. Association for Tropical Lepidoptera, Scientific Publishers, Gainesville.

Mallet J. 2007. Subspecies, semispecies, superspecies. In: Levin S.A. (ed.) Encyclopaedia of Biodiversity 5. Online update 1: 1-5. Elsevier, Oxford.

Mittermeier R.A., Robles Gil P., Hoffmann M., Pilgrim J., Brooks T., Goettsch Mittermeier C., Lamaoreux J. \& Da Fonseca G.A.B. 2004. Hotspots Revisited. Cemex, Mexico City.

Neild A.F.E. 1996. The Butterflies of Venezuela. Part 1: Nymphalidae I (Limenitidinae, Apaturinae, Charaxinae). A comprehensive guide to the identification of adult Nymphalidae, Papilionidae, and Pieridae. Meridian Publications, Greenwich.

Neild A.F.E. 2008. The Butterflies of Venezuela. Part 2: Nymphalidae II (Acraeinae, Libytheinae, Nymphalinae, Ithomiinae, Morphinae). A comprehensive guide to the identification of adult Nymphalidae, Papilionidae, and Pieridae. Meridian Publications, London.

Patten M.A. \& Unitt P. 2002. Diagnosability versus mean differences of Sage Sparrows subspecies. Auk 119: 26-35. http://dx.doi.org/10.1642/0004-8038(2002)119\%5B0026:DVMDOS\%5D2.0.CO;2 
Paynter Jr. R.A. 1992. Ornithological gazetteer of Bolivia, $2^{\text {nd }}$ Ed. Museum of Comparative Zoology, Harvard University, Cambridge, MA.

Paynter R. A. Jr. 1997. Ornithological Gazetteer of Colombia. Museum of Comparative Zoology, Harvard University, Cambridge, MA.

Penz C. 2008. Phylogenetic Revision of Eryphanis Boisduval, with a Description of a New Species from Ecuador (Lepidoptera, Nymphalidae). Insecta Mundi 0035: 1-25.

Piñas F. 2004. Vol. 11a. Familia: Nymphalidae: Subfamilias: Libytheinae, Danainae, Charaxinae, Morphinae, Heliconiiae. Mariposas del Ecuador. Compañía de Jesús, Quito.

Remsen J.V. 2010. Subspecies as a meaningful taxonomic rank in avian classification. Ornithological Monographs 67:62-78.

Rey F. \& Pyrcz T.W. 1996. A perfect mimicry of two cloud forest pierids: Leptophobia eleone and Catasticta revancha n. sp. (Lepidoptera: Pieridae). Genus (Wroclaw) 7(3): 497-502, 3 figs.

Sclater P.L. \& Salvin O. 1879. 2. On the Birds collected in Bolivia by Mr. C. Buckley. Proceedings of the Zoological Society of London 47: 588-645. http://dx.doi.org/10.1111/j.1096-3642.1879.tb02687.x

Silva X. 2011. Ecología de Mariposas del Ecuador. Universidad San Francisco, Quito.

Staudinger O. 1887. VIII. Brassoliden. In: Staudinger O. \& Schatz E. (eds) Exotische Schmetterlinge 1: 211-218. G. Löwensohn, Fürth.

Stichel H. 1904. Lepidoptera Rhopalocera. Fam. Nymphalidae. Subfam. Brassolinae. Genera Insectorum 20: 1-48.

Stichel H. 1909. Brassolidae. Das Tierreich 25. R. Friedländer und Sohn, Berlin.

Stichel H. 1932. Brassolidae. In: Strand E. (ed) Lepidopterorum Catalogus 51. W. Junk, Berlin.

Vane-Wright R.I. 1991. A portrait of Clarence Buckley, zoologist. The Linnean 7(3): 30-33.

Weymer G. \& Maasen J.P. 1890. Lepidopteren gesammelt auf einer Reise durch Colombia, Ecuador, Perú, Brasilien, Argentinien und Bolivien in den Jahren 1868-1877 von Alphons Stübel. A. Asher \& Co, Berlin.

Zink R.M. 2004. The role of subspecies in obscuring avian biological diversity and misleading conservation policy. Proceedings of the Royal Society of London B 271: 561-564. http://dx.doi. org/10.1098/rspb.2003.2617

Manuscript received: 6 August 2013

Manuscript accepted: 28 October 2013

Published on: 3 January 2014

Topic editor: Koen Martens

Desk editor: Natacha Beau

Printed versions of all papers are also deposited in the libraries of the institutes that are members of the EJT consortium: Muséum National d'Histoire Naturelle, Paris, France; National Botanic Garden of Belgium, Meise, Belgium; Royal Museum for Central Africa, Tervuren, Belgium; Natural History Museum, London, United Kingdom; Royal Belgian Institute of Natural Sciences, Brussels, Belgium; Natural history Museum of Denmark, Copenhagen, Denmark 


\section{Appendix 1}

\section{The discovery of the E. zolvizora group: a historical and geographical survey}

In Bolivia, the first specimens of E. zolvizora apparently were collected by Clarence Buckley, who travelled in the country in 1873-75 (Sclater \& Salvin 1879, Vane-Wright 1991, Paynter 1992). The specimen currently considered as the holotype (Fig. 4A), along with one other with the same label data, were bequested to the BMNH in 1879 by W.C. Hewitson (Kirby 1879; BMNH registry records). Later, other specimens were collected at the end of the $19^{\text {th }}$ century by the Garlepp brothers, who worked for the German entomologist and trader Otto Staudinger. Gustav Garlepp collected in various localities, mostly in the departments of Santa Cruz (1890) and Cochabamba (1890-1892). In the BMNH, there is a female he collected at San Jacinto in Cochabamba department (Fig. 7A). Otto Garlepp joined him in 1893, and they collected from 1893 to 1897, and in 1904, in La Paz department (Berlepsch 1901, Paynter 1992, www.zobodat.at/D/runD/D/cacheD/personen details.php? $\mathrm{nr}=7091$ accessed $30 \mathrm{Jul}$. 2013). Other historical specimens were collected by Anton Heinrich Fassl, who worked for two years, from the end of 1912, in the upper Beni basin (La Paz department) (Fassl 1920). More recent specimens from this area, labelled "Caranavi", were provided by insect dealers. Specimens from Cochabamba department labelled "El Palmar", collected in the 1950s, were perhaps provided by Francisco Steinbach, or by Rudolf Zischka, from the locality "El Palmar", along the ancient road from Cochabamba to Villa Tunari. At the end of the 1970s, Nicolas Kuscevic sent specimens to one of the authors (PB) from localities along the new road joining Cochabamba to Villa Tunari, but without precise data. Nevertheless, he regularly collected near Incachaca at $2000 \mathrm{~m}$ (Nicolas Kuscevic, pers. comm.), and his E. zolvizora specimens are with little doubt from this locality. More recently, a few specimens from Santa Cruz, Cochabamba and La Paz departments have been collected by Bolivian entomologists; the southernmost known specimen (Fig. 4B), from Manchones, Santa Cruz department, by one of the authors (YG).

For the purpose of this study, we divided Peru into a southern part, including Puno, Madre de Dios and Cusco departments, a central part, including Junín and Pasco departments, and a northern part, including Huánuco, La Libertad, Cajamarca, San Martín and Amazonas departments. Southern and central specimens are few, and only males are known; nevertheless, they provide reliable information. The oldest specimen we know - a syntype of E. opimus Staudinger, 1887 (Fig. 4E) - was collected in the Chanchamayo valley (Junín department), in 1885, by Franz Thamm, a German collector who worked for Otto Staudinger (Lamas 1981). In the very south, specimens were collected by the Englishman George Richard Ockenden, who made important butterfly collections in Puno from 1900 to 1906 (Lamas 1981). There are a few other old specimens from Chanchamayo/Perené (Junín) and Oxapampa (Pasco) in the Paul Ferdinand Martin collection (MJP). Two males and one female from Cushi near Pozuzo (northern Pasco department, close to Huánuco), were collected by the German Wilhelm Hoffmanns, who worked in central Peru from 1901 to 1904, for Lord Rothschild (Lamas 1981). Some specimens from Cusco and Junín departments have been collected more recently by Peruvian entomologists (Fig. 4C), as well as by trade collectors. Northern males and females are known from different localities. From time to time, specimens from Huánuco department are provided by traders; they were generally collected in the area of Carpish, south of Tingo María. A few specimens have been collected by Peruvian entomologists in La Libertad and Amazonas departments (Fig. 4D). The best information has been gathered for Amazonas populations (Mendoza, San José de Molinopampa and Alto Nieva areas), during Patrick Blandin and Gilbert Lachaume surveys (2005-2012) (Figs. 4F, 7B). Unfortunately, no material is known from the department of Cajamarca nor from the Cordillera del Condor, which forms the border with Ecuador.

Perhaps the oldest Ecuadorian specimens were collected by Marc de Mathan, a French collector who did a tremendous amount of work in northern Peru and Ecuador, between 1879 and 1909 (Lamas 1981). Another French collector, Paul Dognin, who lived in Loja, indicated the presence of Eryphanis opimus (according to his determination) in the surroundings (Dognin 1894). Campos (1927) referred to this 
information in his list of Ecuadorian brassolines. Nevertheless, populations from south-eastern Ecuador (Zamora-Chinchipe province) are poorly known: one female from Parque Podocarpus, Loja (Piñas 2004, figs. 655-656), one male and one female collected by Stéphane Attal (SA, MNHN); two males collected at the end of the 1990s by Artur Jasiński in Zamora-Chinchipe province (MZUJ), and five males collected by Keith Willmott in 1997 and 2006 (FLMNH). Blandin \& Descimon (1975) quoted two males from eastern Ecuador (Tungurahua and Napo provinces), and provided drawings of dorsal and ventral surfaces. In fact, a large number of specimens are known from these provinces, where many people have collected, notably the Velastegui family, since the 1960s. However, many specimens lack precise locality data. Fortunately, Penz (2008) provided detailed information on the population studied by Harold Greeney at the Yanayacu Biological Station (Napo) (Eryphanis greeneyi Penz \& DeVries, 2008; Fig. 5A).

Blandin \& Descimon (1977), in a survey of Brassolini from western Ecuador, were unaware of the existence of "zolvizora" populations. Old specimens of zolvizora labelled from the western village of 'Balzapamba', like many supposedly from this locality, are from eastern Ecuador. The first specimen with good locality data, a female (Fig. 7E), was caught in 1926 by C. Judson Coxey at Huigra (in ANSP), but this specimen, until recently, has been overlooked. There is a female collected in 1982 from 'Santo Domingo' (probably Tinalandia) in LACM. In MZUJ, there is a male collected by Artur Jasiński in 1997, labelled from Balsas, El Oro province; however, this specimen is probably mislabelled (Keith Willmott, pers. comm.); it is likely that it was collected in the Zamora-Chinchipe province. Keith Willmott informed us (pers. comm.) of one male from the Tandayapa Bird Lodge (Pichincha province), on the 28 Nov. 2007, observed by Will Cook; web images of this specimen are available on two sites www.carolinanature.com/pix/ecuador/leps3.html and www.tandaya.com [accessed 30 Jul. 2013]. A male (presumably), attracted to a drinking trough for hummingbirds, was observed and photographed on the 12 Nov. 2009, in the Río Guajalito Reserve, at $1900 \mathrm{~m}$ on the old road from Quito to Santo Domingo (Pichincha) (Xavier Silva, pers. comm.; Silva, 2011). Finally, Tim Kell caught a male (Fig. 5D) at Reserva Las Gralarias (Pichincha) in Apr. 2011.

Colombia has been historically poorly sampled in comparison with other countries rich in butterflies. Label data found on specimens of Eryphanis are often somewhat vague. Therefore, we decided to refer to the following areas: the western slopes of the western cordillera; the Cauca valley and the Magdalena valley, indicating, where possible, their westesrn or eastern slopes; the eastern slopes of the eastern cordillera. The western slopes of the Cauca valley correspond to the eastern side of the western cordillera - generally the Cali area -, and its eastern slopes to the western side of the central cordillera.

Specimens labelled "Bogota" have no reliable location. Eryphanis opimus Staudinger, 1887 was described from Manizales (Fig. 5E). Anton Heinrich Fassl, who travelled in the country from 1908-1912, quoted Eryphanes [sic] opimus Stgr. in association with Opsiphanes camena and Caligo oberthüri [sic] in the western cordillera, without indicating on which side (Fassl 1914), but later he noted opimus on both sides (Fassl 1915a). In the USNM there is one male he collected, labelled 'Río Aguacatal, 2000 m', located on eastern slopes north-west of Cali (Fassl 1914, 1915a). Presumably from the same area, but labelled 'Rio Aguatal' and 'Rio Agua', there are two known females (in UFPC and BMNH) (Fig. 7F). Fassl (1911) did not mention opimus in the central cordillera, despite the fact that a few specimens had been collected in the 1880s. Ultimately, Fassl wrote that E. opimus was very rare on the eastern slopes of the eastern cordillera (Fassl 1915b). To our knowledge, the oldest Colombian specimen, labelled 'Bogota' (UMO), was collected by the British Vice Consul Edward W. Mark between 1848 and 1857.

Today, Colombian populations are known through a few specimens from a limited number of localities. The majority came from the Cauca valley (western slopes and eastern slopes). Two males, in the MNHN and MPM, are labelled "Cali, $1000 \mathrm{~m}$ ". These were apparently provided by a trader who stamped all 
specimens with this "locality". Nonetheless they might have been collected on the road from Cali to Buenaventura. There is a female in the MNHN labelled "Colombie, 1901, H. Donckier, Coll. Boullet", and two males from the same collection labelled "Cauca, 1887, H. Ribbe" and "Cauca, 1903, H. Ribbe". It is presumed that these specimens simply labelled "Cauca" are from the Cauca valley. A male and female (HAGAM) are labelled from Calima Valley, 'Cauca River' [sic], and are therefore probably from the eastern side of the western cordillera. There is one male (JS) from the western side of the western cordillera, km 55. Three specimens (1⿵人, IAvH; $1 \hat{\jmath}, 1$ ㅇ ICNUN; Figs. 5C, 7D), have been collected in the department of Nariño. Information concerning the Magdalena valley and the eastern side of the eastern cordillera remains limited. Two males labelled "Caqueta" (JFLC), almost certainly came from the eastern cordillera on the road between Altamira and Florencia between 1500 and $2000 \mathrm{~m}$ (J.-F. Le Crom, pers. comm.). Recently in 2005, one of the authors (BH) and colleagues discovered a population in the Serranía de los Yariguíes, Santander department, Municipio Galán $(2 \widehat{\jmath}, \mathrm{IAvH})$, in the Magdalena valley, on the western side of the eastern cordillera, and there is one specimen from Charalá (Santander) in MNHN (Fig. 6B).

The first Venezuelan specimen known to us was collected in 1965 by Eduardo Rodríguez and the Romero family in the Cordillera de la Costa (MIZA). Later, in the 1970s, other specimens were collected in this cordillera, the majority by the Romero family in Aragua state on the road from Maracay to Choroní, in the west-central Cordillera de la Costa (Figs. 6C, 8B). In 1972, during an expedition by the MIZA in the Cordillera de Mérida, a pair was collected by Juvenal Salcedo and Felix Zambrano near Anzoátegui in Lara state. Two further populations were subsequently discovered by the Romero family in the mid 1980s in the Santo Domingo valley in Barinas state, on central eastern slopes of the Cordillera de Mérida (Figs. 6A, 8A), and in Táchira state in the northern Sierra de El Tamá, in the area known as Matamula and Pabellón. More recently a female was collected in Vargas state above Maiquetía at 1650 m (incorrectly labelled "La Llanada"; unidentified collector) on the Camino viejo de Los Españoles to Caracas (MNHN), and a population was located in the area around Colonia Tovar in the east-central Cordillera de la Costa (Aragua state) by the Romero family and Mauro Costa. In 2001 a further population was located by Mauro Costa, this time in Mérida state in the central valley of the Cordillera de Mérida, approximately $55 \mathrm{~km} \mathrm{SW}$ of the city of Mérida. While the number of known specimens - especially females - from Venezuela is relatively high compared with other countries, the data indicate that, with rare exceptions, specimens are caught singly and often years apart, indicating great rarity. 


\section{Appendix 2}

\section{List of the studied specimens of Eryphanis zolvizora}

Departments or Provinces have been included (between brackets). Unless they have been provided by collectors, approximate coordinates have been added where possible. Unless otherwise indicated, altitude is given in meters.

- = Specimens on which measurements have been taken directly. = Specimens on which measurements have been taken on scaled pictures. $*$ = Specimens of which genitalia have been dissected.

\begin{tabular}{|c|c|c|c|c|c|}
\hline \multicolumn{6}{|c|}{$\begin{array}{l}\text { Eryphanis zolvizora zolvizora (Hewitson, } 1877) \\
\text { BOLIVIA: Santa Cruz and Cochabamba departments }\end{array}$} \\
\hline Sex & Data & Coord. & Alt. a.s.1. & Reference & Collection \\
\hline$\hat{o}$ & $\begin{array}{l}\text { Camino a Manchones } 17 \text { Apr. 2011, } \\
\text { Y. Gareca leg. (Santa Cruz) }\end{array}$ & $\begin{array}{l}18^{\circ} 45^{\prime} 8.76^{\prime \prime} \mathrm{S} \\
64^{\circ} 0^{\prime} 30.72 ” \mathrm{~W}\end{array}$ & 1695 & & MHNC \\
\hline 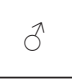 & $\begin{array}{l}\text { Bellavista, 11-15 Oct. 2007, J. Lede, } \\
\text { L. Gomez and A. Alcoba (Santa Cruz) }\end{array}$ & $\begin{array}{l}18^{\circ} 12^{\prime} 00^{\prime \prime} \mathrm{S} \\
63^{\circ} 45^{\prime} 00^{\prime \prime} \mathrm{W} \\
\end{array}$ & 1382 & MHNNKM\#21376 & MHNNKM \\
\hline$\sigma^{\pi}$ & $\begin{array}{l}\text { Bellavista, 11-15 Oct. 2007, J. Lede, } \\
\text { L. Gomez and A. Alcoba (Santa Cruz) }\end{array}$ & $\begin{array}{l}18^{\circ} 12^{\prime} 00^{\prime \prime} \mathrm{S} \\
63^{\circ} 45^{\prime} 00^{\prime \prime} \mathrm{W} \\
\end{array}$ & 1382 & MHNNKM\#21377 & MHNNKM \\
\hline 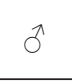 & $\begin{array}{l}\text { Sivingal, Prov. Florida, } 8 \text { Mar. 1991, } \\
\text { W. Rojas leg. (Santa Cruz) }\end{array}$ & & & 6140 & MHNNKM \\
\hline$\sigma^{\pi}$ & Buenavista, 21 Feb. 1994 (Santa Cruz) & & & & FLMNH \\
\hline$\hat{\sigma}$ & Buenavista, 06 Apr. 1925 (Santa Cruz) & & & & FLMNH \\
\hline$\hat{\sigma}$ & $\begin{array}{l}\text { Río Juntas, 1890, G. Garlepp leg. } \\
\text { (Cochabamba) }\end{array}$ & $\begin{array}{l}17^{\circ} 07^{\prime} \mathrm{S} \\
65^{\circ} 16^{\prime} \mathrm{W}\end{array}$ & 1000 & & ZMHB \\
\hline$\delta$ & El Palmar, Apr. 1950 (Cochabamba) & $\begin{array}{l}17^{\circ} 06^{\prime} \mathrm{S} \\
65^{\circ} 17^{\prime} \mathrm{W}\end{array}$ & 1600 & PBB 1408 & MNHN \\
\hline$\hat{\sigma}$ & El Palmar, Nov. 1958 (Cochabamba) & $\begin{array}{l}17^{\circ} 06^{\prime} \mathrm{S} \\
65^{\circ} 17^{\prime} \mathrm{W}\end{array}$ & 1600 & & FLMNH \\
\hline$\delta$ - $*$ & $\begin{array}{l}\text { Probably Incachaca, N. Kuscevic leg. } \\
\text { (Cochabamba) }\end{array}$ & $\begin{array}{l}17^{\circ} 14^{\prime} \mathrm{S} \\
65^{\circ} 49^{\prime} \mathrm{W} \\
\end{array}$ & 2000 & PBB 971 & MNHN \\
\hline$\hat{\theta}$ & Chapare, Oct. 1949 (Cochabamba) & & 300 & PBB 260 & MNHN \\
\hline$\hat{\sigma}$ & $\begin{array}{l}\text { Villa Tunari - Cochabamba, Sillar } \\
\text { Bajo, } 17 \text { Feb. 2009, T. Pircz leg. } \\
\text { (Cochabamba) }\end{array}$ & & 1450 & & MZUJ \\
\hline 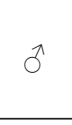 & $\begin{array}{l}\text { Yendo a Chocolatal 12-17 Feb. } 2009 \text {, } \\
\text { Y. Gareca, T. Pircz and J. Wojtusiak } \\
\text { leg. (Cochabamba) }\end{array}$ & $\begin{array}{l}17^{\circ} 08^{\prime} 19.6 ” \mathrm{~S} \\
65^{\circ} 42^{\prime} 43.9^{\prime \prime} \mathrm{W}\end{array}$ & 1518 & & MHNC \\
\hline$\hat{o}$ & $\begin{array}{l}\text { Carmen Pampa 25-28 Sep. 2001, C. } \\
\text { Hamel and A. Pascall (Cochabamba) }\end{array}$ & $\begin{array}{l}16^{\circ} 37^{\prime} 06^{\prime \prime} \mathrm{S} \\
66^{\circ} 28^{\prime} 50^{\prime \prime} \mathrm{W} \\
\end{array}$ & 1820 & & MHNC \\
\hline q & $\begin{array}{l}\text { Locotal, 1891, G. Garlepp leg. } \\
\text { (Cochabamba) }\end{array}$ & $\begin{array}{l}17^{\circ} 11^{\prime} \mathrm{S} \\
65^{\circ} 39^{\prime} \mathrm{W} \\
\end{array}$ & 2600 & & ZMHB \\
\hline q & $\begin{array}{l}\text { San Jacinto, G. Garlepp leg. } \\
\text { (Cochabamba) }\end{array}$ & $\begin{array}{l}17^{\circ} 10^{\prime} \mathrm{S} \\
65^{\circ} 44^{\prime} \mathrm{W}\end{array}$ & $6-8000 \mathrm{ft}$ & $\mathrm{BMNH}(\mathrm{E}) \# 808088$ & BMNH \\
\hline q & El Palmar, Apr. 1947 (Cochabamba) & $\begin{array}{l}17^{\circ} 06^{\prime} \mathrm{S} \\
65^{\circ} 17^{\prime} \mathrm{W} \\
\end{array}$ & 1600 & & FLMNH \\
\hline ${ }^{*}$ & $\begin{array}{l}\text { Probably Incachaca, Kuscevic leg. } \\
\text { (Cochabamba) }\end{array}$ & $\begin{array}{l}17^{\circ} 14^{\prime} \mathrm{S} \\
65^{\circ} 49^{\prime} \mathrm{W}\end{array}$ & 2000 & PBB 1061 & MNHN \\
\hline
\end{tabular}




\begin{tabular}{|c|c|c|c|c|c|}
\hline \multicolumn{6}{|c|}{$\begin{array}{c}\text { Eryphanis zolvizora zolvizora (Hewitson, 1877) } \\
\text { BOLIVIA: La Paz department }\end{array}$} \\
\hline Sex & Data & Coord. & Alt. a.s.l. & Reference & Collection \\
\hline 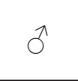 & $\begin{array}{l}\text { R. Tanampaya, 1894, Garlepp leg. } \\
\text { (La Paz) }\end{array}$ & $\begin{array}{l}16^{\circ} 21^{\prime} 46.38^{\prime \prime} \mathrm{S} \\
67^{\circ} 35^{\prime} 34.73 \text { '” }\end{array}$ & 1146 & BMNH(E)\#808077 & BMNH \\
\hline 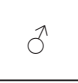 & Chaco, 1894, Garlepp leg. (La Paz) & $\begin{array}{l}16^{\circ} 19^{\prime} 59.76^{\prime \prime} \mathrm{S} \\
67^{\circ} 47^{\prime} 59.67^{\prime \prime} \mathrm{W}\end{array}$ & $2000-3000$ & & ZMHB \\
\hline$\hat{0}$ & $\begin{array}{l}\text { Tunquini-El Chairo, 2003, F. Guerra } \\
\text { leg. (La Paz) }\end{array}$ & $\begin{array}{l}16^{\circ} 12^{\prime} 28.42 ” \mathrm{~S} \\
67^{\circ} 522^{\prime} 59.92^{\prime \prime} \mathrm{W}\end{array}$ & 1600 & MHNNKM6037 & MHNNKM \\
\hline$\hat{o}$ & $\begin{array}{l}\text { Nor Yungas PN-ANMI Cotapata Est. } \\
\text { Biológica Tunquini, Sep. 1999, J. } \\
\text { Corro leg. (La Paz) }\end{array}$ & $\begin{array}{l}16^{\circ} 12^{\prime} 28.42^{\prime \prime} \mathrm{S} \\
67^{\circ} 52^{\prime} 59.92^{\prime} \mathrm{W}\end{array}$ & 1600 & CBF-1125 & $\mathrm{CBF}$ \\
\hline It & $\begin{array}{l}\text { San Antonio, Mar. 1896, Garlepp leg. } \\
\text { (La Paz) }\end{array}$ & $\begin{array}{l}17^{\circ} 14^{\prime} \mathrm{S} \\
65^{\circ} 19^{\prime} \mathrm{W}\end{array}$ & 1200 & BMNH(E)\#808071 & $\mathrm{BMNH}$ \\
\hline$\sigma^{\pi}$ & $\begin{array}{l}\text { San Antonio, 1896, Garlepp leg. } \\
\text { (La Paz) }\end{array}$ & $\begin{array}{l}17^{\circ} 14^{\prime} \mathrm{S} \\
65^{\circ} 19^{\prime} \mathrm{W}\end{array}$ & 1800 & & ZMHB \\
\hline$\sigma^{\pi}$ & Coroico, 1914, A.H. Fassl leg. (La Paz) & $\begin{array}{l}16^{\circ} 10^{\prime} \mathrm{S} \\
67^{\circ} 44^{\prime} \mathrm{W} \\
\end{array}$ & 1200 & $\mathrm{BMNH}(\mathrm{E}) \# 808076$ & BMNH \\
\hline o & Coroico, A.H. Fassl leg. (La Paz) & $\begin{array}{l}16^{\circ} 10^{\prime} \mathrm{S} \\
67^{\circ} 44^{\prime} \mathrm{W}\end{array}$ & 1200 & $\begin{array}{l}\text { Coleção Julius Arp } \\
\mathrm{N}^{\circ} 18 / 537\end{array}$ & UFPC \\
\hline 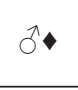 & Coroico, A.H. Fassl leg. (La Paz) & $\begin{array}{l}16^{\circ} 10^{\prime} \mathrm{S} \\
67^{\circ} 44^{\prime} \mathrm{W}\end{array}$ & 1200 & & USNM \\
\hline$\hat{0}$ & Coroico (La Paz) & $\begin{array}{l}16^{\circ} 10^{\prime} \mathrm{S} \\
67^{\circ} 44^{\prime} \mathrm{W}\end{array}$ & 1200 & BMNH(E)\#808073 & BMNH \\
\hline$\hat{0}$ & Coroico, E.H. Page leg. (La Paz) & $\begin{array}{l}16^{\circ} 10^{\prime} \mathrm{S} \\
67^{\circ} 44^{\prime} \mathrm{W} \\
\end{array}$ & 1200 & & BMNH \\
\hline$\hat{0}$ & Coroico (La Paz) & $\begin{array}{l}16^{\circ} 10^{\prime} \mathrm{S} \\
67^{\circ} 44^{\prime} \mathrm{W}\end{array}$ & 1200 & & RAMM \\
\hline 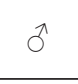 & $\begin{array}{l}\text { Zongo, Rio } 16 \text { Mar. 1979, Schmitt leg. } \\
\text { (La Paz) }\end{array}$ & $\begin{array}{l}15^{\circ} 47^{\prime} \mathrm{S} \\
67^{\circ} 44^{\prime} \mathrm{W}\end{array}$ & & & AMNH \\
\hline 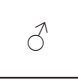 & Farinas (La Paz) & $\begin{array}{l}15^{\circ} 55^{\prime} \mathrm{S} \\
67^{\circ} 47^{\prime} \mathrm{W} \\
\end{array}$ & & & RAMM \\
\hline ôn & "Caranavi" (La Paz) & $\begin{array}{l}15^{\circ} 56^{\prime} 02 ” \mathrm{~S} \\
67^{\circ} 27^{\prime} 42^{\prime \prime} \mathrm{W} \\
\end{array}$ & & PBB 2153 & MNHN \\
\hline j"* & "Caranavi” (La Paz) & $\begin{array}{l}15^{\circ} 56^{\prime} 02 ” \mathrm{~S} \\
67^{\circ} 27^{\prime} 42^{\prime \prime} \mathrm{W} \\
\end{array}$ & & PBB 2286 & MNHN \\
\hline 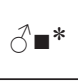 & “Caranavi” (La Paz) & $\begin{array}{l}15^{\circ} 56^{\prime} 02 ” \mathrm{~S} \\
67^{\circ} 27^{\prime} 42^{\prime \prime} \mathrm{W} \\
\end{array}$ & & PBB 2287 & MNHN \\
\hline$\hat{0}$ & $\begin{array}{l}\text { Nor Yungas, Villa Incahuara, Caranavi, } \\
\text { C. Tello Egg leg. (La Paz) }\end{array}$ & $\begin{array}{l}15^{\circ} 23 ’ 37.81 ’ \mathrm{~S} \\
67^{\circ} 40^{\prime} 25.30^{\prime \prime} \mathrm{W}\end{array}$ & & CBF-4529 & $\mathrm{CBF}$ \\
\hline$\hat{\delta} \mathbf{m}$ & $\begin{array}{l}\text { Nord Yungas 26-27 Jan. 1984, T. } \\
\text { Porion leg. (La Paz) }\end{array}$ & & 1600 & PBB 1410 & MNHN \\
\hline$\hat{0}$ & Las Yungas, Nov. 1990 (La Paz?) & & & & FLMNH \\
\hline$\hat{0}$ & $\begin{array}{l}\text { Bolivie, Garlepp leg. (Staudinger } \\
\text { 1895) (La Paz) }\end{array}$ & & & BMNH(E)\#808074 & BMNH \\
\hline ${ }^{*}$ & Coroico, A.H. Fassl leg. (La Paz) & $\begin{array}{l}16^{\circ} 10^{\prime} \mathrm{S} \\
67^{\circ} 44^{\prime} \mathrm{W} \\
\end{array}$ & 1200 & $\begin{array}{l}\text { BMNH(E)\#808089 } \\
\text { VIAL } 8577 \\
\end{array}$ & BMNH \\
\hline q & Coroico, A.H. Fassl leg. (La Paz) & $\begin{array}{l}16^{\circ} 10^{\prime} \mathrm{S} \\
67^{\circ} 44^{\prime} \mathrm{W}\end{array}$ & 1200 & BMNH(E)\#808090 & BMNH \\
\hline 우 & Coroico, A.H. Fassl leg. (La Paz) & $\begin{array}{l}16^{\circ} 10^{\prime} \mathrm{S} \\
67^{\circ} 44^{\prime} \mathrm{W}\end{array}$ & 1200 & $\begin{array}{l}\text { Coleção Julius Arp } \\
\mathrm{N}^{\circ} 18 / 538\end{array}$ & UFPC \\
\hline
\end{tabular}


BLANDIN P. et al., Revision of the Andean Eryphanis zolvizora group

\begin{tabular}{|c|c|c|c|c|c|}
\hline \multicolumn{6}{|c|}{$\begin{array}{l}\text { Eryphanis zolvizora zolvizora (Hewitson, 1877) } \\
\text { BOLIVIA: La Paz department (continued) }\end{array}$} \\
\hline Sex & Data & Coord. & Alt. a.s.l. & Reference & Collection \\
\hline$q$ & $\begin{array}{l}\text { Zongo, Pacollo, } 8 \text { Feb. } 1991 \text { (noche), } \\
\text { R. Coreticona leg. (La Paz) }\end{array}$ & $\begin{array}{l}16^{\circ} 02^{\prime} 29^{\prime \prime} \mathrm{S} \\
67^{\circ} 58^{\prime} 26^{\prime \prime} \mathrm{W}\end{array}$ & & CBF- 4530 & $\mathrm{CBF}$ \\
\hline ${ }^{*}$ & $\begin{array}{l}\text { Río Songo, 1910, A.H. Fassl leg. (La } \\
\text { Paz) }\end{array}$ & $\begin{array}{l}15^{\circ} 43^{\prime} \mathrm{S} \\
67^{\circ} 41^{\prime} \mathrm{W}\end{array}$ & & $\mathrm{CG}$ & MNHN \\
\hline
\end{tabular}

\begin{tabular}{|c|c|c|c|c|c|}
\hline \multicolumn{6}{|c|}{$\begin{array}{l}\text { Eryphanis zolvizora zolvizora (Hewitson, 1877) } \\
\text { BOLIVIA: specimens without precise or reliable locality }\end{array}$} \\
\hline Sex & Data & Coord. & Alt. a.s.l. & Reference & Collection \\
\hline$\hat{0}$ & $\begin{array}{l}\text { Bolivia (Buckley) Hewitson } \\
\text { Coll. 79-69. } \\
\text { Pavonia zolzivora Hew, } 2\end{array}$ & & & $\begin{array}{c}\text { BMNH(E)\#705086 } \\
\text { BM TYPE } 6110 \\
\text { SYNTYPE } \\
\text { E. zolvizora }\end{array}$ & $\mathrm{BMNH}$ \\
\hline$\hat{0}$ & [Bolivia] Hewitson 1 & & & $\begin{array}{c}\text { SYNTYPE E. } \\
\text { zolvizora }\end{array}$ & $\mathrm{BMNH}$ \\
\hline$\sigma^{\lambda}$ & Bolivia & & & BMNH(E)\#808091 & $\mathrm{BMNH}$ \\
\hline$\sigma^{\lambda}$ & Bolivia & & & BMNH(E)\#808092 & $\mathrm{BMNH}$ \\
\hline$\sigma^{\lambda}$ & Bolivia & & & BMNH(E)\#808072 & $\mathrm{BMNH}$ \\
\hline$\hat{\sigma}$ & Bolivia (Levick) & & & BMNH(E)\#808075 & $\mathrm{BMNH}$ \\
\hline$\partial$ & Bolivia & & & $\begin{array}{c}\text { Coleção Julius Arp } \\
N^{\circ} 18 / 536\end{array}$ & UFPC \\
\hline$\partial \mathbf{m}$ & Bolivie & & & PBB 1409 & MNHN \\
\hline Ō* & Bolivie (O. Staudinger, 1902) & & & CG & MNHN \\
\hline$\partial$ & Bolivia & & & & USNM \\
\hline$\hat{0}$ & Bolivia & & & & RAMM \\
\hline q & Negnejahuza, May 1926 & & & & AMNH \\
\hline
\end{tabular}




\begin{tabular}{|c|c|c|c|c|c|}
\hline \multicolumn{6}{|c|}{$\begin{array}{l}\text { Eryphanis zolvizora inca Blandin, ssp. nov. } \\
\text { PERU: Puno, Cuzco, Junín and Pasco departments }\end{array}$} \\
\hline Sex & Data & Coord. & Alt. a.s.l. & Reference & Collection \\
\hline$\partial *$ & $\begin{array}{l}\text { Santo Domingo, Carabaya, Jan. } 1901 \\
\text { Wet season, G.R. Ockenden leg. } \\
\text { (Puno) }\end{array}$ & $\begin{array}{l}13^{\circ} 50^{\prime} \mathrm{S} \\
69^{\circ} 40^{\prime} \mathrm{W}\end{array}$ & $6000 \mathrm{ft}$ & $\begin{array}{c}\text { BMNH }(\mathrm{E}) \# \\
806244 \\
\text { VIAL } 8223\end{array}$ & $\mathrm{BMNH}$ \\
\hline$\partial *$ & $\begin{array}{l}\text { Santo Domingo, Carabaya, } 1901 \text { Dry } \\
\text { season, G.R. Ockenden leg. (Puno) }\end{array}$ & $\begin{array}{l}13^{\circ} 50^{\prime} \mathrm{S} \\
69^{\circ} 40^{\prime} \mathrm{W}\end{array}$ & $4500 \mathrm{ft}$ & $\begin{array}{c}\text { BMNH (E) \# } \\
808079 \\
\text { VIAL } 8576\end{array}$ & $\mathrm{BMNH}$ \\
\hline$\partial$ & $\begin{array}{l}\text { Santo Domingo, Carabaya, } 1901 \text { Dry } \\
\text { season G.R. Ockenden leg. (Puno) }\end{array}$ & $\begin{array}{l}13^{\circ} 50^{\prime} \mathrm{S} \\
69^{\circ} 40^{\prime} \mathrm{W}\end{array}$ & $4500 \mathrm{ft}$ & $\begin{array}{l}\text { BMNH (E) \# } \\
808078\end{array}$ & $\mathrm{BMNH}$ \\
\hline$\lambda$ & Inca Minas, 1 Jul. 1900 (Puno) & $\begin{array}{l}13^{\circ} 50^{\prime} \mathrm{S} \\
69^{\circ} 40^{\prime} \mathrm{W}\end{array}$ & & & AMNH \\
\hline$\lambda$ & Carabaya (Puno) & $\begin{array}{l}14^{\circ} 05^{\prime} \mathrm{S} \\
70^{\circ} 27^{\prime} \mathrm{W}\end{array}$ & & & $\mathrm{AMNH}$ \\
\hline$\hat{\sigma}$ & Inambari (Puno) & & & $\begin{array}{l}\text { BMNH (E)\# } \\
525986\end{array}$ & $\mathrm{BMNH}$ \\
\hline$\partial$ & $\begin{array}{l}\text { Chirimayo, Jun. 1901Dry season, G.R. } \\
\text { Ockenden leg. (Puno) }\end{array}$ & $\begin{array}{l}13^{\circ} 27^{\prime} \mathrm{S} \\
70^{\circ} 18^{\prime} \mathrm{W}\end{array}$ & $1000 \mathrm{ft}$ & $\begin{array}{l}\text { BMNH (E) \# } \\
808081\end{array}$ & $\mathrm{BMNH}$ \\
\hline a & San Lorenzo, Río Marcapata (Cusco) & & & PBB 2115 & MNHN \\
\hline$\partial$ & $\begin{array}{l}\text { San Pedro, 4-8 Nov. 2007, F. \& A. } \\
\text { West leg. (Cusco) }\end{array}$ & $\begin{array}{l}13^{\circ} 03^{\prime} \mathrm{S} \\
71^{\circ} 33^{\prime} \mathrm{W}\end{array}$ & 1400 & & MJP \\
\hline$\partial *$ & $\begin{array}{l}\text { Aguas Calientes, } 21 \text { Oct. 2001, G. } \\
\text { Lamas leg. (Cusco) }\end{array}$ & $\begin{array}{l}13^{\circ} 09^{\prime} \mathrm{S} \\
72^{\circ} 31^{\prime} \mathrm{W}\end{array}$ & 2050 & $\begin{array}{c}\text { Genitalia } \\
\text { MJPZOLV 003PB }\end{array}$ & MJP \\
\hline$\partial$ & $\begin{array}{l}\text { Marchu Pijchu [sic] A. Larichesy leg. } \\
\text { (Cusco) }\end{array}$ & & 2000 & IG 10375 & IRSN \\
\hline$\hat{0}$ & $\begin{array}{l}\text { Macchu Picchu [sic], } 10 \text { Dec. 1987, J. } \\
\text { Dubois leg. (Cusco) }\end{array}$ & & & & $\begin{array}{l}\text { MNHN, } \\
\text { CG }\end{array}$ \\
\hline ô* & $\begin{array}{l}\text { Llacatahuamán, Quebrada Bagre, } 27 \\
\text { Jul. 1998, G. Valencia leg. (Cusco) }\end{array}$ & $\begin{array}{l}12^{\circ} 52^{\prime} \mathrm{S} \\
73^{\circ} 30^{\prime} \mathrm{W}\end{array}$ & 1700 & $\begin{array}{c}\text { Genitalia } \\
\text { MJPZOLV 001PB }\end{array}$ & MJP \\
\hline$\delta$ ' $*$ & $\begin{array}{l}\text { Alfamayo, route Ollantaytambo- } \\
\text { Quillabamba, M. Cabrera leg. (Cusco) }\end{array}$ & & & PBB 2184 & MNHN \\
\hline 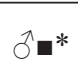 & $\begin{array}{l}\text { Calabaza, Pampa Hermosa, prov. } \\
\text { Satipo, Apr. } 2008 \text { (Junín) }\end{array}$ & $\begin{array}{c}11^{\circ} 29^{\prime} 2.02 \mathrm{~S} \\
74^{\circ} 47^{\prime} 39.25^{\prime \prime} \mathrm{W}\end{array}$ & 2200 & PBB 2308 & MNHN \\
\hline$\lambda$ & Chanchamayo, (Junín) & $\begin{array}{c}11^{\circ} 04^{\prime} \mathrm{S} \\
75^{\circ} 19^{\prime} \mathrm{W}\end{array}$ & 1500 & & AMNH \\
\hline Jै* & Río Perené (Junín) & & & $\begin{array}{c}\text { Genitalia } \\
\text { MJPZOLV 005PB }\end{array}$ & MJP \\
\hline$\partial *$ & Oxapampa (Pasco) & & & $\begin{array}{c}\text { Genitalia } \\
\text { MJPZOLV 007PB }\end{array}$ & MJP \\
\hline
\end{tabular}


BLANDIN P. et al., Revision of the Andean Eryphanis zolvizora group

\begin{tabular}{|c|c|c|c|c|c|}
\hline \multicolumn{6}{|c|}{$\begin{array}{l}\text { Eryphanis zolvizora chachapoya Blandin, ssp. nov. } \\
\text { PERU: Junín, Pasco, Huánuco and La Libertad departments }\end{array}$} \\
\hline Sex & Data & Coord. & Alt. a.s.1. & Reference & Collection \\
\hline$\partial^{\lambda}$ & $\begin{array}{l}\text { Chanchamayo, 1885, F. Thamm leg. } \\
\text { (Junín) }\end{array}$ & $\begin{array}{l}11^{\circ} 04^{\prime} \mathrm{S} \\
75^{\circ} 19^{\prime} \mathrm{W}\end{array}$ & & $\begin{array}{l}\text { SYNTYPE } \\
\text { E. opimus }\end{array}$ & BMNH \\
\hline$\delta$ ○* & $\begin{array}{l}\text { San Francisco, Chanchamayo, Jan. } \\
\text { 1964, Mme Harris leg. (Junín) }\end{array}$ & & & PBB 1407 & MNHN \\
\hline Jै* & Río Perené (Junín) & & & $\begin{array}{c}\text { Genitalia } \\
\text { MJPZOLV 006PB }\end{array}$ & MJP \\
\hline Jै* & $\begin{array}{l}\text { Oxapampa, La Suiza, 5-13 Jun. 2002, } \\
\text { B. Wenezel leg. (Pasco) }\end{array}$ & & 2180 & & UFPC \\
\hline ô* & Huancabamba (Pasco) & $\begin{array}{l}10^{\circ} 23^{\prime} \mathrm{S} \\
75^{\circ} 33^{\prime} \mathrm{W}\end{array}$ & $6800 \mathrm{ft}$ & $\begin{array}{c}\text { BMNH (E)\# } \\
806245 \text { VIAL } 8224\end{array}$ & $\mathrm{BMNH}$ \\
\hline$\partial *$ & Cushi, W. Hoffmans leg. (Pasco) & $\begin{array}{l}09^{\circ} 58^{\prime} \mathrm{S} \\
75^{\circ} 42^{\prime} \mathrm{W}\end{array}$ & 1820 & $\begin{array}{c}\text { BMNH (E)\# } \\
\text { 806246 VIAL } 8225\end{array}$ & $\mathrm{BMNH}$ \\
\hline$\hat{\sigma}$ & Cushi, W. Hoffmans leg. (Pasco) & $\begin{array}{l}09^{\circ} 58^{\prime} \mathrm{S} \\
75^{\circ} 42^{\prime} \mathrm{W}\end{array}$ & 1900 & & BMNH \\
\hline ${ }^{*}$ & Cushi, W. Hoffmans leg. (Pasco) & $\begin{array}{l}09^{\circ} 58^{\prime} \mathrm{S} \\
75^{\circ} 42^{\prime} \mathrm{W}\end{array}$ & 1900 & $\begin{array}{c}\text { BMNH (E)\# } \\
806247 \text { VIAL } 8226\end{array}$ & BMNH \\
\hline$\partial$ & $\begin{array}{l}\text { Panao, Jan. 1982, Schunke leg., } \\
\text { (Huánuco) }\end{array}$ & $\begin{array}{l}09^{\circ} 54^{\prime} \mathrm{S} \\
75^{\circ} 58^{\prime} \mathrm{W}\end{array}$ & 3000 & & UFPC \\
\hline$\delta \mathbf{\square}^{*}$ & Carpish, (Huánuco) & $\begin{array}{l}09^{\circ} 43^{\prime} \mathrm{S} \\
76^{\circ} 06^{\prime} \mathrm{W}\end{array}$ & & PBB 259 & MNHN \\
\hline$\delta \mathbf{\square}^{\prime} *$ & Carpish, Jan. 2006 (Huánuco) & $\begin{array}{l}09^{\circ} 43^{\prime} \mathrm{S} \\
76^{\circ} 06^{\prime} \mathrm{W}\end{array}$ & 2300 & PBB 2284 & MNHN \\
\hline$\delta$ - $*$ & Carpish, Apr. 2008 (Huánuco) & $\begin{array}{l}09^{\circ} 43^{\prime} \mathrm{S} \\
76^{\circ} 06^{\prime} \mathrm{W}\end{array}$ & 2800 & PBB 2311 & MNHN \\
\hline$\hat{\delta} \mathbf{m} *$ & Probably Carpish (Huánuco) & & $1500-2000$ & PBB 2326 & MNHN \\
\hline$\varphi^{*}$ & Carpish, Jul. 2005 (Huánuco) & $\begin{array}{l}09^{\circ} 43^{\prime} \mathrm{S} \\
76^{\circ} 06^{\prime} \mathrm{W}\end{array}$ & 2300 & PBB 2285 & MNHN \\
\hline $\varphi^{*}$ & Mallqui, (Huánuco) & & $1500-2000$ & PBB 2327 & MNHN \\
\hline$\partial *$ & $\begin{array}{l}\text { Cumpang, entre Tayabamba y Ongon, } \\
21 \text { Oct. 1979, T. Parker, leg. (La } \\
\text { Libertad) }\end{array}$ & $\begin{array}{l}08^{\circ} 16^{\prime} \mathrm{S} \\
77^{\circ} 00^{\prime} \mathrm{W}\end{array}$ & $2400-2700$ & $\begin{array}{l}\text { Genitalia } \\
\text { MJPZOLV 004PB }\end{array}$ & MJP \\
\hline
\end{tabular}

\begin{tabular}{|c|c|c|c|c|c|}
\hline \multicolumn{6}{|c|}{$\begin{array}{c}\text { Eryphanis zolvizora chachapoya Blandin, ssp. nov. } \\
\text { PERU : Amazonas, San Martín }\end{array}$} \\
\hline Sex & Data & Coord. & Alt. a.s.1. & Reference & Collection \\
\hline 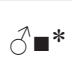 & $\begin{array}{l}\text { Mendoza area, Jun. 1994, B. Calderón } \\
\text { leg. (Amazonas) }\end{array}$ & $\begin{array}{l}06^{\circ} 23^{\prime} \mathrm{S} \\
77^{\circ} 27 \mathrm{~W}\end{array}$ & & PBB 1900 & MNHN \\
\hline$\delta \square^{\prime} *$ & $\begin{array}{l}\text { Mendoza area, Nov. 2006, B. Calderón } \\
\text { leg. (Amazonas) }\end{array}$ & $\begin{array}{l}06^{\circ} 23^{\prime} \mathrm{S} \\
77^{\circ} 27 \mathrm{~W}\end{array}$ & & PBB 2289 & MNHN \\
\hline Jै* & $\begin{array}{l}\text { Valle de Huamanpata, Lejia, } 23 \text { Oct. } \\
\text { 2005, L. Campos leg. (Amazonas) }\end{array}$ & $\begin{array}{l}06^{\circ} 20^{\prime} \mathrm{S} \\
77^{\circ} 27^{\prime} \mathrm{W}\end{array}$ & 2150 & $\begin{array}{c}\text { Genitalia } \\
\text { MJPZOLV 002PB }\end{array}$ & MJP \\
\hline$\partial \mathbf{q}^{\prime} *$ & $\begin{array}{l}\text { San José de Molinopampa, } 20 \text { May } \\
2005 \\
\text { B. Calderón leg. (Amazonas) }\end{array}$ & $\begin{array}{l}06^{\circ} 12^{\prime} \mathrm{S} \\
77^{\circ} 34^{\prime} \mathrm{W}\end{array}$ & $2200-2400$ & PBGL 153 & MNHN \\
\hline ô* & $\begin{array}{l}\text { San José de Molinopampa, } 2005 \\
\text { B. Calderón leg. (Amazonas) }\end{array}$ & $\begin{array}{l}06^{\circ} 12^{\prime} \mathrm{S} \\
77^{\circ} 34^{\prime} \mathrm{W}\end{array}$ & $2200-2400$ & PBGL 166 & MNHN \\
\hline
\end{tabular}




\begin{tabular}{|c|c|c|c|c|c|}
\hline \multicolumn{6}{|c|}{$\begin{array}{l}\text { Eryphanis zolvizora chachapoya Blandin, ssp. nov. } \\
\text { PERU : Amazonas, San Martín (continued) }\end{array}$} \\
\hline Sex & Data & Coord. & Alt. a.s.1. & Reference & Collection \\
\hline$\partial \div *$ & $\begin{array}{l}\text { San José de Molinopampa, } 20 \text { May } \\
2005 \text { B. Calderón leg. (Amazonas) }\end{array}$ & $\begin{array}{l}06^{\circ} 12^{\prime} \mathrm{S} \\
77^{\circ} 34^{\prime} \mathrm{W}\end{array}$ & $2200-2400$ & PBGL 190 & MNHN \\
\hline$\delta$ ( $*$ & $\begin{array}{l}\text { San José de Molinopampa, Mar. } 2005 \\
\text { B. Calderón leg. (Amazonas) }\end{array}$ & $\begin{array}{l}06^{\circ} 12^{\prime} \mathrm{S} \\
77^{\circ} 34^{\prime} \mathrm{W}\end{array}$ & $2200-2400$ & PBGL 296 & MNHN \\
\hline$\delta$ ( $*$ & $\begin{array}{l}\text { San José de Molinopampa, 2008, } \\
\text { B. Calderón leg. (Amazonas) }\end{array}$ & $\begin{array}{l}06^{\circ} 12^{\prime} \mathrm{S} \\
77^{\circ} 34^{\prime} \mathrm{W}\end{array}$ & $2200-2400$ & PBB 2309 & MNHN \\
\hline$\hat{0}$ & $\begin{array}{l}\text { Oso Perdido, Dec. 2011, J.C. Pintado } \\
\text { leg. (Amazonas) }\end{array}$ & $\begin{array}{c}05^{\circ} 43^{\prime} \mathrm{S} \\
77^{\circ} 50-51^{\prime} \mathrm{W}\end{array}$ & $2200-2400$ & PBB 2324 & MNHN \\
\hline 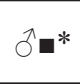 & $\begin{array}{l}\text { Le long de l'alto río Nieva, 4-9 Mar. } \\
2009 \text { (Amazonas) }\end{array}$ & $\begin{array}{l}05^{\circ} 42^{\prime} 40^{\prime \prime} \mathrm{S} \\
77^{\circ} 47^{\prime} 15^{\prime \prime} \mathrm{W}\end{array}$ & 2250 & PBGL 471 & MNHN \\
\hline$\partial *$ & $\begin{array}{l}\text { Le long de l'alto río Nieva, } 9 \text { Mar. } \\
2009 \text { (Amazonas) }\end{array}$ & $\begin{array}{l}05^{\circ} 42^{\prime} 40^{\prime \prime} \mathrm{S} \\
77^{\circ} 47^{\prime} 15^{\prime \prime} \mathrm{W}\end{array}$ & 2250 & PBGL 518 & MNHN \\
\hline$\delta$ - & Alto Nieva (Amazonas) & $\begin{array}{l}05^{\circ} 39^{\prime} \mathrm{S} \\
77^{\circ} 47^{\prime} \mathrm{W}\end{array}$ & 1900 & PBB 2156 & MNHN \\
\hline$\partial \div *$ & Alto Nieva (Amazonas) & $\begin{array}{l}05^{\circ} 40^{\prime} \mathrm{S} \\
77^{\circ} 46^{\prime} \mathrm{W}\end{array}$ & 1900 & PBB 2157 & MNHN \\
\hline$\hat{0}$ & $\begin{array}{l}\text { Alto Nieva, Dec. 2012, J. C. Pintado } \\
\text { leg. (Amazonas) }\end{array}$ & $\begin{array}{l}05^{\circ} 40^{\prime} \mathrm{S} \\
77^{\circ} 46^{\prime} \mathrm{W}\end{array}$ & 1900 & PBB 2325 & MNHN \\
\hline$\delta$ - & $\begin{array}{l}\text { Nieva, Mar. 2010, J.C. Pintado leg. } \\
\text { (Amazonas) }\end{array}$ & $\begin{array}{l}05^{\circ} 40^{\prime} \mathrm{S} \\
77^{\circ} 46^{\prime} \mathrm{W}\end{array}$ & 1900 & PBGL 592 & MNHN \\
\hline$\hat{\delta}$ - & $\begin{array}{l}\text { Villa Hermosa, vallée du río } \\
\text { Nieva, Dec. 2010, J.C. Pintado leg. } \\
\text { (Amazonas) }\end{array}$ & $\begin{array}{c}05^{\circ} 36^{\prime} \mathrm{S} \\
77^{\circ} 47^{\prime} \mathrm{W}\end{array}$ & 1500 & PBGL 594 & MNHN \\
\hline$\partial \mathbf{\square}$ & $\begin{array}{l}\text { Nieva, Sep. 2011, J.C. Pintado leg. } \\
\text { (Amazonas) }\end{array}$ & $\begin{array}{l}05^{\circ} 40^{\prime} \mathrm{S} \\
77^{\circ} 46^{\prime} \mathrm{W}\end{array}$ & 1900 & PBGL 595 & MNHN \\
\hline $*$ & $\begin{array}{l}\text { San José de Molinopampa, } 15 \text { Jan. } \\
\text { 2007, B. Calderón leg. (Amazonas) }\end{array}$ & $\begin{array}{l}06^{\circ} 12^{\prime} \mathrm{S} \\
77^{\circ} 34^{\prime} \mathrm{W}\end{array}$ & $2200-2400$ & PBGL 198 & MNHN \\
\hline $*^{*}$ & $\begin{array}{l}\text { Alto Nieva, Mar. 2010, J.C. Pintado } \\
\text { leg. (Amazonas) }\end{array}$ & $\begin{array}{l}05^{\circ} 40^{\prime} \mathrm{S} \\
77^{\circ} 46^{\prime} \mathrm{W}\end{array}$ & $1900-2000$ & PBGL 519 & MNHN \\
\hline o* & $\begin{array}{l}\text { Alto Nieva, camino a Villa Hermosa, } \\
\text { Feb. 2010, J.C. Pintado leg. } \\
\text { (Amazonas) }\end{array}$ & $\begin{array}{c}05^{\circ} 40^{\prime} \mathrm{S} \\
77^{\circ} 46^{\prime} \mathrm{W}\end{array}$ & $1900-2000$ & PBGL 520 & MNHN \\
\hline o & $\begin{array}{l}\text { Río Jenesis, Nov. 2012, J. C. Pintado } \\
\text { leg. (Amazonas) }\end{array}$ & $\begin{array}{l}05^{\circ} 32-33 ’ \mathrm{~S} \\
77^{\circ} 48-49^{\prime} \mathrm{W}\end{array}$ & $1400-1600$ & & MJP \\
\hline $q^{*}$ & $\begin{array}{l}\text { Nieva, Sep. 2011, J.C. Pintado leg. } \\
\text { (Amazonas) }\end{array}$ & $\begin{array}{l}05^{\circ} 40^{\prime} \mathrm{S} \\
77^{\circ} 46^{\prime} \mathrm{W}\end{array}$ & 1900 & PBGL 596 & MNHN \\
\hline$\hat{\delta}=*$ & $\begin{array}{l}\text { El Choferrito, Alto Mayo, Oct. 2010, } \\
\text { J.C. Pintado leg. (San Martín) }\end{array}$ & $\begin{array}{l}05^{\circ} 40^{\prime} \mathrm{S} \\
77^{\circ} 45^{\prime} \mathrm{W}\end{array}$ & 1800 & PBGL 593 & MNHN \\
\hline 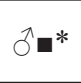 & $\begin{array}{l}\text { Jorge Chavez, Alto Mayo, } 9 \text { Nov. } 2006 \\
\text { (San Martín) }\end{array}$ & $\begin{array}{l}5^{\circ} 40-41 ’ \mathrm{~S} \\
77^{\circ} 43-44 ’ \mathrm{~W}\end{array}$ & $1300-1400$ & PBGL 470 & MNHN \\
\hline$\hat{\sigma} \mathbf{m *}$ & Jorge Chavez, Alto Mayo, (San Martín) & $\begin{array}{l}5^{\circ} 40-41^{\prime} \mathrm{S} \\
77^{\circ} 43-44 ’ \mathrm{~W}\end{array}$ & $1300-1400$ & PBB 2283 & MNHN \\
\hline$\hat{\partial} \boldsymbol{m} *$ & $\begin{array}{l}\text { Jorge Chavez, Alto Mayo, Sep. } 2007 \\
\text { (San Martín) }\end{array}$ & $\begin{array}{l}5^{\circ} 40-41^{\prime} \mathrm{S} \\
77^{\circ} 43-44 ’ \mathrm{~W}\end{array}$ & $1300-1400$ & PBB 2310 & MNHN \\
\hline$\hat{\partial}=*$ & $\begin{array}{l}\text { San Augustín, Naranjos area, } 4 \text { Nov. } \\
2006 \text { (San Martín) }\end{array}$ & $\begin{array}{c}5^{\circ} 47^{\prime} \mathrm{S} \\
77^{\circ} 30^{\prime} \mathrm{W}\end{array}$ & 1400 & PBGL 521 & MNHN \\
\hline 우 & $\begin{array}{l}\text { San Augustín, Naranjos area, Sep. } \\
2012 \text { (San Martín) }\end{array}$ & $\begin{array}{c}5^{\circ} 47^{\prime} \mathrm{S} \\
77^{\circ} 30^{\prime} \mathrm{W}\end{array}$ & 1400 & & MJP \\
\hline
\end{tabular}


BLANDIN P. et al., Revision of the Andean Eryphanis zolvizora group

\begin{tabular}{|c|c|c|c|c|c|}
\hline \multicolumn{6}{|c|}{$\begin{array}{l}\text { Eryphanis zolvizora greeneyi Penz \& DeVries, } 2008 \\
\text { EASTERN ECUADOR: Zamora-Chinchipe, Morona-Santiago and Pastaza provinces }\end{array}$} \\
\hline Sex & Data & Coord. & Alt. a.s.l. & Reference & Collection \\
\hline$\hat{\sigma}$ & $\begin{array}{l}\text { Cordillera Llagunillas, Rd. San } \\
\text { Andreas - Calderón, } 20 \text { May } 1998 \\
\text { (Zamora-Chinchipe) }\end{array}$ & & $2000-2600$ & & MUZJ \\
\hline$\delta$ & $\begin{array}{l}\text { Romerillos, ridge to west, } 1 \text { Nov. 1997, } \\
\text { K. R. Willmott (Zamora-Chinchipe) }\end{array}$ & $\begin{array}{l}4^{\circ} 11.0^{\prime} \mathrm{S} \\
78^{\circ} 56.50 \mathrm{~W}\end{array}$ & 1600 & & FLMNH \\
\hline$\hat{0}$ & $\begin{array}{l}\text { San Francisco, casa de Arcoiris, km } \\
\text { 24 Loja-Zamora rd., } 14 \text { Sep. 2006, } \\
\text { K.R. Willmott, R. Aldaz leg. (Zamora- } \\
\text { Chinchipe) }\end{array}$ & $\begin{array}{l}3^{\circ} 59.30^{\prime} \mathrm{S} \\
79^{\circ} 5.58^{\prime} \mathrm{W}\end{array}$ & $2000-2100$ & FLMNH\# 111778 & FLMNH \\
\hline 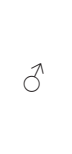 & $\begin{array}{l}\text { San Francisco, casa de Arcoiris, km } \\
24 \text { Loja-Zamora rd., } 27 \text { Oct. 2006, } \\
\text { K.R. Willmott, R. Aldaz leg. (Zamora- } \\
\text { Chinchipe) }\end{array}$ & $\begin{array}{l}3^{\circ} 59.30^{\prime} \mathrm{S} \\
79^{\circ} 5.58^{\prime} \mathrm{W}\end{array}$ & $2000-2100$ & FLMNH\# 111779 & FLMNH \\
\hline$\sigma^{\pi}$ & $\begin{array}{l}\text { San Francisco, casa de Arcoiris, km } \\
24 \text { Loja-Zamora rd., } 27 \text { Oct. 2006, } \\
\text { K.R. Willmott, R. Aldaz leg. (Zamora- } \\
\text { Chinchipe) }\end{array}$ & $\begin{array}{l}3^{\circ} 59.30^{\prime} \mathrm{S} \\
79^{\circ} 5.58^{\prime} \mathrm{W}\end{array}$ & $2000-2100$ & FLMNH\# 111776 & FLMNH \\
\hline 0 & $\begin{array}{l}\text { San Francisco, casa de Arcoiris, km } 24 \\
\text { Loja-Zamora rd., } 2 \text { Nov. 2006, K.R. } \\
\text { Willmott leg. (Zamora-Chinchipe) }\end{array}$ & $\begin{array}{l}3^{\circ} 59.30^{\prime} \mathrm{S} \\
79^{\circ} 5.58^{\prime} \mathrm{W}\end{array}$ & $2000-2100$ & FLMNH\# 111777 & FLMNH \\
\hline ôn & $\begin{array}{l}\text { Río San Francisco (Río Zamora), } 12 \\
\text { Oct. 2006, S. Attal leg. (Zamora- } \\
\text { Chinchipe) }\end{array}$ & $\begin{array}{l}03^{\circ} 58^{\prime} \mathrm{S} \\
79^{\circ} 05^{\prime} \mathrm{W}\end{array}$ & 2000 & & SA \\
\hline$q *$ & $\begin{array}{l}\text { Valladolid, } 03 \text { Jan. 2002, S. Attal leg. } \\
\text { (Zamora-Chinchipe) }\end{array}$ & $\begin{array}{l}04^{\circ} 34^{\prime} \mathrm{S} \\
79^{\circ} 08^{\prime} \mathrm{W}\end{array}$ & & PBB 2288 & MNHN \\
\hline 우 & $\begin{array}{l}\text { Parque Podocarpus, } 1 \text { May 1999, M. } \\
\text { Kling (Loja) }\end{array}$ & $\begin{array}{l}04^{\circ} 06^{\prime} \mathrm{S} \\
78^{\circ} 57^{\prime} \mathrm{W}\end{array}$ & 2000 & 0656 & FP \\
\hline$\hat{\sigma}$ & $\begin{array}{l}\text { Macas-Guamote, Sept. 1999, Estevez } \\
\text { leg. (Morona-Santiago) }\end{array}$ & $\begin{array}{l}02^{\circ} 16^{\prime} \mathrm{S} \\
78^{\circ} 10^{\prime} \mathrm{W}\end{array}$ & 1500 & & $\mathrm{MECN}$ \\
\hline Ŝn & Puyo area, Feb. 1996 (Pastaza) & & & PBB 2328 & MNHN \\
\hline
\end{tabular}

\begin{tabular}{|c|c|c|c|c|c|}
\hline \multicolumn{6}{|c|}{$\begin{array}{l}\text { Eryphanis zolvizora greeneyi Penz \& DeVries, } 2008 \\
\text { EASTERN ECUADOR: Tungurahua, Napo and Sucumbíos provinces }\end{array}$} \\
\hline Sex & Data & Coord. & Alt. a.s.l. & Reference & Collection \\
\hline 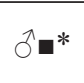 & Machay, Jan. 1994 (Tungurahua) & $\begin{array}{l}01^{\circ} 24^{\prime} \mathrm{S} \\
78^{\circ} 18^{\prime} \mathrm{W}\end{array}$ & $1800-2200$ & PBB 1899 & MNHN \\
\hline$\delta$ ○* & Machay, 14 Feb. 1995 (Tungurahua) & $\begin{array}{l}01^{\circ} 24^{\prime} \mathrm{S} \\
78^{\circ} 18^{\prime} \mathrm{W}\end{array}$ & $1800-2200$ & PBB 2166 & MNHN \\
\hline 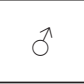 & Machay, 1 Aug. 1997 (Tungurahua) & $\begin{array}{l}01^{\circ} 24^{\prime} \mathrm{S} \\
78^{\circ} 18^{\prime} \mathrm{W}\end{array}$ & $1800-2200$ & & MUZJ \\
\hline$\delta$ ( $*$ & Río Blanco, 3 May 1972 (Tungurahua) & $\begin{array}{l}01^{\circ} 23^{\prime} \mathrm{S} \\
78^{\circ} 20^{\prime} \mathrm{W}\end{array}$ & 1700 & PBB 729 & MNHN \\
\hline$\delta$ (口* & $\begin{array}{l}\text { Río Blanco, San José, } 10 \text { Jun. } 1967 \\
\text { (Tungurahua) }\end{array}$ & $\begin{array}{l}01^{\circ} 23^{\prime} \mathrm{S} \\
78^{\circ} 20^{\prime} \mathrm{W}\end{array}$ & 1700 & PBB 257 & MNHN \\
\hline$\delta$ ○* & $\begin{array}{l}\text { Río Blanco, } 25 \text { Apr. } 1966 \\
\text { (Tungurahua) }\end{array}$ & $\begin{array}{l}01^{\circ} 23^{\prime} \mathrm{S} \\
78^{\circ} 20^{\prime} \mathrm{W}\end{array}$ & 1700 & PBB 537 & MNHN \\
\hline 3 & $\begin{array}{l}\text { Río Blanco, } 25 \text { Aug. } 1937 \\
\text { (Tungurahua) }\end{array}$ & $\begin{array}{l}01^{\circ} 23^{\prime} \mathrm{S} \\
78^{\circ} 20^{\prime} \mathrm{W}\end{array}$ & 1800 & & USNM \\
\hline
\end{tabular}




\begin{tabular}{|c|c|c|c|c|c|}
\hline \multicolumn{6}{|c|}{$\begin{array}{l}\text { Eryphanis zolvizora greeneyi Penz \& DeVries, } 2008 \\
\text { EASTERN ECUADOR: Tungurahua, Napo and Sucumbíos provinces (continued) }\end{array}$} \\
\hline Sex & Data & Coord. & Alt. a.s.l. & Reference & Collection \\
\hline 0 & Río Blanco (Tungurahua) & $\begin{array}{l}01^{\circ} 23^{\prime} \mathrm{S} \\
78^{\circ} 20^{\prime} \mathrm{W}\end{array}$ & 1800 & & PW \\
\hline 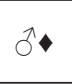 & $\begin{array}{l}\text { Río Blanco, near Baños, } 17 \text { Apr. } 1956 \\
\text { (Tungurahua) }\end{array}$ & $\begin{array}{l}01^{\circ} 23^{\prime} \mathrm{S} \\
78^{\circ} 20^{\prime} \mathrm{W}\end{array}$ & 1650 & $\begin{array}{l}\text { scaled picture, } \\
\text { C. Penz }\end{array}$ & MPM \\
\hline$\hat{0}$ & $\begin{array}{l}\text { Río Blanco, } 28 \text { Dec. } 1938 \\
\text { (Tungurahua) }\end{array}$ & $\begin{array}{l}01^{\circ} 23^{\prime} \mathrm{S} \\
78^{\circ} 20^{\prime} \mathrm{W}\end{array}$ & & $\mathrm{BMNH}(\mathrm{E}) \# 808100$ & $\mathrm{BMNH}$ \\
\hline$\sigma^{\pi}$ & Río Verde, 6 May 2001 (Tungurahua) & $\begin{array}{l}01^{\circ} 24^{\prime} \mathrm{S} \\
78^{\circ} 17^{\prime} \mathrm{W}\end{array}$ & 1500 & & PW \\
\hline$\hat{0}$ & $\begin{array}{l}\text { Río Verde, E. Ecuador, M.G. Palmer } \\
\text { (Tungurahua) }\end{array}$ & $\begin{array}{l}01^{\circ} 24^{\prime} \mathrm{S} \\
78^{\circ} 17^{\prime} \mathrm{W}\end{array}$ & $5000 \mathrm{ft}$ & $\mathrm{BMNH}(\mathrm{E}) \# 808082$ & $\mathrm{BMNH}$ \\
\hline$\hat{\sigma}$ & Ambato, Anda Vazconez (Tungurahua) & & & BMNH(E)\#808084 & $\mathrm{BMNH}$ \\
\hline$\hat{\sigma}$ & Ambato, Anda Vazconez (Tungurahua) & & & BMNH(E)\#808085 & $\mathrm{BMNH}$ \\
\hline$\hat{0}$ & $\begin{array}{l}\text { Env. d' Ambato. R. P. Blanc } \\
\text { (Tungurahua) }\end{array}$ & & & BMNH(E)\#808086 & $\mathrm{BMNH}$ \\
\hline$\widehat{o}$ & $\begin{array}{l}\text { Equateur Or. de Baños a Canelos. M. } \\
\text { de Mathan } 9 \text { Oct. 1894. (Tungurahua/ } \\
\text { Pastaza) }\end{array}$ & & & BMNH(E)\#808083 & $\mathrm{BMNH}$ \\
\hline$q$ & $\begin{array}{l}\text { Río Verde, E. Ecuador, M.G. Palmer } \\
\text { (Tungurahua) }\end{array}$ & $\begin{array}{l}01^{\circ} 24^{\prime} \mathrm{S} \\
78^{\circ} 17^{\prime} \mathrm{W}\end{array}$ & $5000 \mathrm{ft}$ & BMNH(E)\#808097 & $\mathrm{BMNH}$ \\
\hline q & Yunguilla, Juil. 1937 (Tungurahua) & $\begin{array}{l}01^{\circ} 12^{\prime} \mathrm{S} \\
78^{\circ} 20^{\prime} \mathrm{W}\end{array}$ & $1900-2000$ & & $\mathrm{AMNH}$ \\
\hline$q$ & $\begin{array}{l}\text { Biscaya (= Viscaya), } 7 \text { May } 1996 \\
\text { (Tungurahua) }\end{array}$ & $\begin{array}{l}01^{\circ} 20^{\prime} 34^{\prime \prime} \mathrm{S} \\
78^{\circ} 24^{\prime} 07^{\prime \prime} \mathrm{W}\end{array}$ & & & MUZJ \\
\hline$\hat{n} *$ & Río Arajuno, 27 Mar. 1968 (Napo) & $\begin{array}{l}01^{\circ} 14 ’ \mathrm{~S} \\
77^{\circ} 42^{\prime} \mathrm{W}\end{array}$ & 700 & PBB 258 & MNHN \\
\hline$\hat{\sigma}$ & $\begin{array}{l}\text { El Arrayán, Baeza, } 28 \text { Dec.1997, I. } \\
\text { Manzano (Napo) }\end{array}$ & & 2000 & 0654 & FP \\
\hline 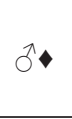 & $\begin{array}{l}\text { Yanayacu Biological Station, } 5 \mathrm{~km} \mathrm{~W} \\
\text { of Cosanga, May 2007, reared by H.F. } \\
\text { Greeney, (Napo) }\end{array}$ & $\begin{array}{l}00^{\circ} 35,9^{\prime} \mathrm{S} \\
77^{\circ} 53,4^{\prime} \mathrm{W}\end{array}$ & 2163 & $\begin{array}{c}\text { HOLOTYPE } \\
\text { E. greeneyi } \\
\text { BMNH(E)\#808102 }\end{array}$ & $\mathrm{BMNH}$ \\
\hline$\partial$ & $\begin{array}{l}\text { Yanayacu Biological Station, reared, } \\
\text { 2006, H. Greeney, (Napo) }\end{array}$ & $\begin{array}{l}00^{\circ} 35,9^{\prime} \mathrm{S} \\
77^{\circ} 53,4^{\prime} \mathrm{W}\end{array}$ & 2163 & & BMNH \\
\hline$\hat{\sigma}$ & Napo & & 465 & & PW \\
\hline q & $\begin{array}{l}\text { Yanayacu Biological Station, May } \\
\text { 2007, reared by H.F. Greeney, (Napo) }\end{array}$ & $\begin{array}{l}00^{\circ} 35^{\prime} \mathrm{S} \\
77^{\circ} 53^{\prime} \mathrm{W}\end{array}$ & 2163 & $\begin{array}{c}\text { PARATYPE } \\
\text { E. greeneyi } \\
\text { BMNH(E)\#808103 } \\
\end{array}$ & $\mathrm{BMNH}$ \\
\hline 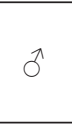 & $\begin{array}{l}\text { Río Palmar, km } 16.5 \text { La Bonita- } \\
\text { Rosa Florida rd., } 23 \text { Nov. 1996, K.R. } \\
\text { Willmott leg. (Sucumbíos) }\end{array}$ & $\begin{array}{l}0^{\circ} 25.10^{\prime} \mathrm{N} \\
77^{\circ} 32.20^{\prime} \mathrm{W}\end{array}$ & 1200 & & FLMNH \\
\hline
\end{tabular}


BLANDIN P. et al., Revision of the Andean Eryphanis zolvizora group

\begin{tabular}{|c|c|c|c|c|c|}
\hline \multicolumn{6}{|c|}{$\begin{array}{l}\text { Eryphanis zolvizora greeneyi Penz \& DeVries, } 2008 \\
\text { EASTERN ECUADOR: specimens without precise or reliable locality }\end{array}$} \\
\hline Sex & Data & Coord. & Alt. a.s.l. & Reference & Collection \\
\hline 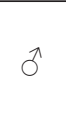 & $\begin{array}{l}\text { Balsas, } 14 \text { Apr. 1997, K. Jasińsly } \\
\text { leg. (mislabelled? K. Willmott pers. } \\
\text { comm.) }\end{array}$ & & $800-1100$ & & MUZJ \\
\hline 0 & $\begin{array}{l}\text { Balzapamba, Ecuador occ. } \\
\text { (mislabelled) }\end{array}$ & & & & FLMNH \\
\hline 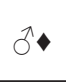 & $\begin{array}{l}\text { Balzapamba, Ecuador occ. } \\
\text { (mislabelled) }\end{array}$ & & & & USNM \\
\hline q & $\begin{array}{l}\text { Equateur, 'Balzapamba'. Prov. de } \\
\text { Bolivar. M. de Mathan Oct. } 1893 \text { - } \\
\text { Feb. } 1894 \text { (mislabelled) }\end{array}$ & & & BMNH(E)\#808098 & $\mathrm{BMNH}$ \\
\hline 우 & Balzapamba (mislabelled) & & & & $\mathrm{BMNH}$ \\
\hline $0^{\pi}$ & Ecuador & & & & $\mathrm{AMNH}$ \\
\hline $0^{\lambda}$ & Ecuador & & & & PW \\
\hline 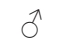 & Ecuador (Levick collection) & & & BMNH(E)\#808087 & $\mathrm{BMNH}$ \\
\hline 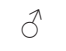 & Ecuador & & & BMNH(E)\#808101 & $\mathrm{BMNH}$ \\
\hline 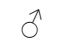 & Ecuador & & & BMNH(E)\#808099 & $\mathrm{BMNH}$ \\
\hline$\sigma^{\pi}$ & Ecuador & & & & NNM \\
\hline$\sigma^{\pi}$ & Ecuador & & & & ZMUA \\
\hline q & Oriente & & & & $\mathrm{AMNH}$ \\
\hline 울 & Ecuador, Velastegui leg. & & & & JFLC \\
\hline
\end{tabular}

\begin{tabular}{|c|c|c|c|c|c|}
\hline \multicolumn{6}{|c|}{$\begin{array}{l}\text { Eryphanis zolvizora uncertain ssp., cf. greeneyi Penz \& DeVries, } 2008 \\
\text { COLOMBIA: southern Cordillera Oriental }\end{array}$} \\
\hline Sex & Data & Coord. & Alt. a.s.l. & Reference & Collection \\
\hline $2 \widehat{\partial}$ & $\begin{array}{l}\text { [Altamira-Florencia road], Caqueta, } \\
\text { Mar. 1987, Urbina leg. }\end{array}$ & & $1500-2000$ & & JFLC \\
\hline
\end{tabular}

\begin{tabular}{|c|l|c|c|c|c|}
\hline \multicolumn{5}{|c|}{$\begin{array}{c}\text { Eryphanis zolvizora greeneyi Penz \& DeVries, } 2008 \\
\text { COLOMBIA: specimen without reliable locality }\end{array}$} \\
\hline Sex & \multicolumn{1}{|c|}{ Data } & Coord. & Alt. a.s.l. & Reference & Collection \\
\hline \multirow{\delta}{*}{$\begin{array}{l}\text { Puerto Nariño, 20-30 Jul. 1980 } \\
\text { (Amazonas) }\end{array}$} & $\begin{array}{c}3^{\circ} 45^{\prime} \mathrm{N} \\
70^{\circ} 20^{\prime} \mathrm{W}\end{array}$ & 150 & & LACM \\
\hline
\end{tabular}




\begin{tabular}{|c|c|c|c|c|c|}
\hline \multicolumn{6}{|c|}{$\begin{array}{l}\text { Eryphanis zolvizora casagrande Bristow, ssp. nov. } \\
\text { WESTERN ECUADOR: Pichincha and Chimborazo provinces }\end{array}$} \\
\hline Sex & Data & Coord. & Alt. a.s.1. & Reference & Collection \\
\hline o゙* & $\begin{array}{l}\text { Reserves Las Gralarias, } 27 \text { Apr. 2011, } \\
\text { T.Kell (Pichincha) }\end{array}$ & $\begin{array}{c}0^{\circ} 00^{\prime} 39^{\prime \prime} \mathrm{S} \\
78^{\circ} 43^{\prime} 50^{\prime \prime} \mathrm{W} \\
\end{array}$ & $1800-2050$ & 151126 & FLMNH \\
\hline q & $\begin{array}{l}\text { Santo Domingo [Tinalandia ?], Apr. } \\
1980 \text { (Pichincha) }\end{array}$ & & 200 & & LACM \\
\hline o & $\begin{array}{l}\text { Tandayapa Lodge, } 28 \text { Nov. 2007, Will } \\
\text { Cook (Pichincha) }\end{array}$ & $\begin{array}{c}0^{\circ} 10^{\prime} \mathrm{S} \\
78^{\circ} 46^{\prime} \mathrm{W}\end{array}$ & 1600 & & Web image \\
\hline ¿’? & $\begin{array}{l}\text { Río Guajalito Reserve, } 12 \text { Nov. } \\
\text { 2009,old road from Quito to Santo } \\
\text { Domingo (Pichincha) }\end{array}$ & & 1900 & & $\begin{array}{l}\text { Picture } \\
\text { p. } 101 \text { in } \\
\text { Silva } 2011\end{array}$ \\
\hline 우 & Huigra, Nov. 1926 (Chimborazo) & $\begin{array}{l}02^{\circ} 18^{\prime} \mathrm{S} \\
78^{\circ} 59^{\prime} \mathrm{W}\end{array}$ & 1220 & & ANSP \\
\hline
\end{tabular}

\begin{tabular}{|c|l|c|c|c|c|}
\hline \multicolumn{5}{|c|}{$\begin{array}{c}\text { Eryphanis zolvizora casagrande Bristow, ssp. nov. } \\
\text { ECUADOR: specimen without reliable locality }\end{array}$} \\
\hline Sex & \multicolumn{1}{|c|}{ Data } & Coord. & Alt. a.s.l. & Reference & Collection \\
\hline \multirow{2}{*}{$\begin{array}{l}\text { Valladolid, 17 May 1998, K. } \\
\text { Jasiński leg. (Zamora-Chinchipe) } \\
\text { (mislabelled?) }\end{array}$} & & & MUZJ \\
\hline
\end{tabular}

\begin{tabular}{|c|c|c|c|c|c|}
\hline \multicolumn{6}{|c|}{$\begin{array}{c}\text { Eryphanis zolvizora casagrande Bristow, ssp. nov. } \\
\text { COLOMBIA: Nariño department }\end{array}$} \\
\hline Sex & Data & Coord. & Alt. a.s.l. & Reference & Collection \\
\hline j* & $\begin{array}{l}\text { Altaquer, Río Ñambi, Jul. } 1995 \\
\text { (Nariño) }\end{array}$ & $\begin{array}{l}01^{\circ} 15^{\prime} \mathrm{N} \\
78^{\circ} 07^{\prime} \mathrm{W} \\
\end{array}$ & 1380 & $\begin{array}{c}\text { GAC } 7615 \text { ICN- } \\
\text { MNH-L } 14791 \\
\end{array}$ & ICNUN \\
\hline$\delta^{\lambda *}$ & $\begin{array}{l}\text { Ricaurte, La Planada, } 8 \text { Sep. 1994, } \\
\text { Julian Salazar leg. (Nariño) }\end{array}$ & $\begin{array}{l}01^{\circ} 05^{\prime} 06^{\prime \prime} \mathrm{N} \\
77^{\circ} 53^{\prime} 06^{\prime \prime} \mathrm{W}\end{array}$ & 1800 & $\begin{array}{l}\text { IAvH } 8238 \text { S.M. } \\
4385 \text { Gen. JFL } 336\end{array}$ & $\mathrm{IAvH}$ \\
\hline q* & $\begin{array}{l}\text { Reserva La Planada, via Hondón } \\
\text { Trampa : Malaise H2, } 16 \text { 0ct.-2 Nov. } \\
2000 \text { G.. Oliva leg. (Nariño) }\end{array}$ & $\begin{array}{l}01^{\circ} 15^{\prime} \mathrm{N} \\
78^{\circ} 15^{\prime} \mathrm{W}\end{array}$ & 1930 & $\begin{array}{l}\text { IAvH-E } 67776 \\
\text { Gen. JFL } 337\end{array}$ & $\mathrm{IAvH}$ \\
\hline
\end{tabular}


BLANDIN P. et al., Revision of the Andean Eryphanis zolvizora group

\begin{tabular}{|c|c|c|c|c|c|}
\hline \multicolumn{6}{|c|}{$\begin{array}{c}\text { Eryphanis zolvizora opimus Staudinger, } 1887 \\
\text { COLOMBIA: Caldas, Risaralda, Antioquia and Valle del Cauca departments }\end{array}$} \\
\hline Sex & Data & Coord. & Alt. a.s.l. & Reference & Collection \\
\hline$\sigma^{\pi}$ & Manizales (Caldas) & $\begin{array}{l}05^{\circ} 05^{\prime} \mathrm{N} \\
75^{\circ} 32^{\prime} \mathrm{W}\end{array}$ & 2500 & $\begin{array}{l}\text { SYNTYPE E. } \\
\text { opimus }\end{array}$ & ZMHB \\
\hline$\sigma^{\lambda}$ & Manizales (Caldas) & $\begin{array}{l}05^{\circ} 05^{\prime} \mathrm{N} \\
75^{\circ} 32^{\prime} \mathrm{W}\end{array}$ & 2500 & $\begin{array}{l}\text { SYNTYPE E. } \\
\text { opimus }\end{array}$ & ZMHB \\
\hline$\delta^{1 *}$ & Manizales. A.M. Patiño. (Caldas) & $\begin{array}{l}05^{\circ} 05^{\prime} \mathrm{N} \\
75^{\circ} 32^{\prime} \mathrm{W}\end{array}$ & & $\begin{array}{l}\text { BMNH(E)\#806249 } \\
\text { VIAL } 8228\end{array}$ & $\mathrm{BMNH}$ \\
\hline$\delta^{\lambda *}$ & $\begin{array}{l}\text { Col. (Cauca) Distrito de Pereira. } \\
\text { Roman Valencia. } 1886 \text { (Risaralda) }\end{array}$ & & & $\begin{array}{l}\text { BMNH(E)\#806248 } \\
\text { VIAL } 8227\end{array}$ & $\mathrm{BMNH}$ \\
\hline$\hat{\sigma}$ & $\begin{array}{l}\text { Col. (Cauca) Distrito de Pereira. } \\
\text { Roman Valencia. } 1886 \text { (Risaralda) }\end{array}$ & & & BMNH(E)\#808096 & $\mathrm{BMNH}$ \\
\hline $4 \hat{\jmath}$ & Mesopotamia (Antioquia) & $\begin{array}{l}05^{\circ} 51^{\prime} \mathrm{N} \\
75^{\circ} 16^{\prime} \mathrm{W}\end{array}$ & 900 & & AMNH \\
\hline ô* & $\begin{array}{l}\text { Vallée du Quindio, environs Arménia } \\
\text { Mme Farre Duchartre leg. } 1930 \\
\text { (Quindio) }\end{array}$ & $\begin{array}{l}04^{\circ} 25^{\prime} \mathrm{N} \\
75^{\circ} 23^{\prime} \mathrm{W}\end{array}$ & 1800 & $\mathrm{CG}$ & MNHN \\
\hline$\delta^{7 *}$ & Cauca Valley & & & $\begin{array}{l}\text { BMNH(E)\#806250 } \\
\text { VIAL } 8229\end{array}$ & $\mathrm{BMNH}$ \\
\hline$\hat{O} \mathbf{m}$ & Cauca, H. Ribbe, 1887 & & & $\mathrm{CG}$ & MNHN \\
\hline ô* & Cauca C. Ribbe, 1903 & & & $\mathrm{CG}$ & MNHN \\
\hline ja* & “Cali”, 11 Aug. 1974 (Valle del Cauca) & & 1000 & PBB 1406 & MNHN \\
\hline 3 & $\begin{array}{l}\text { Cali, } 23 \text { Sep. } 1964 \\
\text { J.R. Neidhoefer Collection }\end{array}$ & & 1000 & $\begin{array}{l}\text { 07-32 dissected by } \\
\text { C. M. Penz }\end{array}$ & MPM \\
\hline$\partial^{\lambda}$ & $\begin{array}{l}\text { Calima Valley, Cauca River, Nov. } 1988 \\
\text { (Greenwood) (Valle del Cauca) }\end{array}$ & $\begin{array}{l}03^{\circ} 53^{\prime} \mathrm{N} \\
76^{\circ} 36^{\prime} \mathrm{W} \\
\end{array}$ & 1300 & & HAGAM \\
\hline 3 & $\begin{array}{l}\text { Río Aguacatal, Colomb. West Cord. } \\
\text { Coll. Fassl (Valle del Cauca) }\end{array}$ & $\begin{array}{l}03^{\circ} 34^{\prime} \mathrm{N} \\
76^{\circ} 40^{\prime} \mathrm{W}\end{array}$ & 2000 & & USNM \\
\hline q & $\begin{array}{l}\text { Calima Valley, Cauca River, } 19 \text { May } \\
1988 \text { (Greenwood) (Valle del Cauca) }\end{array}$ & $\begin{array}{l}03^{\circ} 53^{\prime} \mathrm{N} \\
76^{\circ} 36^{\prime} \mathrm{W}\end{array}$ & 1300 & & HAGAM \\
\hline q & $\begin{array}{l}\text { R. Aguatal (presumably río Aguacatal, } \\
\text { Valle del Cauca) }\end{array}$ & & 1800 & $\begin{array}{l}\text { Coleção Julius } \\
\operatorname{Arp~N}^{\circ} 18 / 540 \\
\end{array}$ & UFPC \\
\hline q & $\begin{array}{l}\text { R. Agua (presumably río Aguacatal, } \\
\text { Valle del Cauca) }\end{array}$ & & & & $\mathrm{BMNH}$ \\
\hline$\hat{\sigma}$ & $\begin{array}{l}\text { Valle, km 55, west side, } 3 \text { Oct. } 1985 \text {, } \\
\text { J. Salazar }\end{array}$ & & & & JS \\
\hline
\end{tabular}




\begin{tabular}{|c|c|c|c|c|c|}
\hline \multicolumn{6}{|c|}{$\begin{array}{l}\text { Eryphanis zolvizora opimus Staudinger, } 1887 \\
\text { COLOMBIA: specimens without precise or reliable locality }\end{array}$} \\
\hline Sex & Data & Coord. & Alt. a.s.l. & Reference & Collection \\
\hline$\widehat{0}$ & $\begin{array}{l}\text { Buenaventura-Queremal } 4 \text { May 1985, } \\
\text { Schmidt-Mumm leg. (mislabelled?) }\end{array}$ & $\begin{array}{l}03^{\circ} 37^{\prime} \mathrm{N} \\
76^{\circ} 53^{\prime} \mathrm{W}\end{array}$ & 200 & & $\mathrm{IAvH}$ \\
\hline$\hat{\delta}$ & Bogota, Colombia & & & BMNH(E)\#808094 & $\mathrm{BMNH}$ \\
\hline 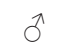 & Bogota & & & BMNH(E)\#808095 & BMNH \\
\hline$\hat{\sigma}$ & $\begin{array}{l}\text { Bogota, between } 1848 \text { and } 1857, \\
\text { Edward. W. Mark, British Vice Consul }\end{array}$ & & & & UMO \\
\hline$\hat{\jmath}$ & Bogota & & & & USNM \\
\hline$q *$ & Colombie, H. Donckier, 1901 & & & $\mathrm{CG}$ & MNHN \\
\hline
\end{tabular}

\begin{tabular}{|c|c|c|c|c|c|}
\hline \multicolumn{6}{|c|}{$\begin{array}{l}\text { Eryphanis zolvizora reyi Bristow, Neild, De Sousa \& Huertas ssp. nov. } \\
\text { COLOMBIA : northern Cordillera Oriental }\end{array}$} \\
\hline Sex & Data & Coord. & $\begin{array}{l}\text { Alt. } \\
\text { a.s.l. }\end{array}$ & Reference & Collection \\
\hline J* & $\begin{array}{l}\text { El Cerro-La Luchata, Municipio } \\
\text { Galan, } 29 \text { Jun. 2006, B. Huertas, J.C. } \\
\text { Rios \& J.J. Arias leg., Proyecto YARE } \\
\text { (Santander) }\end{array}$ & $\begin{array}{l}06^{\circ} 37^{\prime} 75^{\prime \prime} \mathrm{N} \\
73^{\circ} 18^{\prime} 88^{\prime \prime} \mathrm{W}\end{array}$ & $1950-2050$ & & $\mathrm{IAvH}$ \\
\hline$\widehat{\sigma}$ & $\begin{array}{l}\text { El Cerro-La Luchata, Municipio } \\
\text { Galan, } 30 \text { Jun. 2006, B. Huertas, J.C. } \\
\text { Rios \& J.J. Arias leg., Proyecto YARE } \\
\text { (Santander) }\end{array}$ & $\begin{array}{l}06^{\circ} 37^{\prime} 75^{\prime \prime} \mathrm{N} \\
73^{\circ} 18^{\prime} 88^{\prime \prime} \mathrm{W}\end{array}$ & $1950-2050$ & & $\mathrm{IAvH}$ \\
\hline 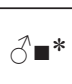 & Charalá Jul. 2008 (Santander) & $\begin{array}{l}06^{\circ} 15^{\prime} \mathrm{N} \\
73^{\circ} 05^{\prime} \mathrm{W}\end{array}$ & 2000 & PBB 2321 & MNHN \\
\hline
\end{tabular}

\begin{tabular}{|c|c|c|c|c|c|}
\hline \multicolumn{6}{|c|}{$\begin{array}{c}\text { Eryphanis zolvizora reyi Bristow, Neild, De Sousa \& Huertas ssp. nov. } \\
\text { VENEZUELA: Táchira, Mérida, Barinas and Lara states }\end{array}$} \\
\hline Sex & Data & Coord. & Alt. a.s.1. & Reference & Collection \\
\hline$\hat{\partial} \mathbf{m}$ & $\begin{array}{l}\text { Sierra de El Tamá, Vía Delicia, Mar. } \\
1987 \text { (Estado Táchira) }\end{array}$ & $\begin{array}{c}7^{\circ} 36^{\prime} \mathrm{N} \\
72^{\circ} 26^{\prime} \mathrm{W}\end{array}$ & 1900 & & $\mathrm{R}$ \\
\hline$\hat{\partial} \mathbf{m}$ & $\begin{array}{l}\text { Sierra de El Tamá, Vía Delicia } \\
\text { (Pabellón), Apr.1990 (Edo. Táchira) }\end{array}$ & $\begin{array}{l}7^{\circ} 36^{\prime} \mathrm{N} \\
72^{\circ} 26^{\prime} \mathrm{W}\end{array}$ & 1700 & & $\mathrm{R}$ \\
\hline ${ }^{*}$ & $\begin{array}{l}\text { Páramo El Molino, SE of Sta. Cruz de } \\
\text { Mora, NW Venezuela. } 3 \text { Jan. 2001, M. } \\
\text { Costa leg. (Mérida) }\end{array}$ & $\begin{array}{c}8^{\circ} 16^{\prime} \mathrm{N} \\
71^{\circ} 34^{\prime} \mathrm{W}\end{array}$ & 1600 & & AN \\
\hline 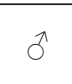 & $\begin{array}{l}\text { La Mina, above San Isidro, Mar. 1988, } \\
\text { Legit Romero (Barinas) }\end{array}$ & $\begin{array}{c}8^{\circ} 50^{\prime} \mathrm{N} \\
70^{\circ} 34^{\prime} \mathrm{W}\end{array}$ & 1450 & & AN \\
\hline$\hat{\partial} \mathbf{m}$ & $\begin{array}{l}\text { Barinitas [La Mina de San Isidro], } \\
\text { Oct. 1987. Estado Barinas. }\end{array}$ & $\begin{array}{c}8^{\circ} 50^{\prime} \mathrm{N} \\
70^{\circ} 34^{\prime} \mathrm{W}\end{array}$ & 1450 & & $\mathrm{R}$ \\
\hline ô* & $\begin{array}{l}\text { Barinitas. [La Mina de San Isidro], } \\
\text { Oct. 1987. (Barinas) }\end{array}$ & $\begin{array}{c}8^{\circ} 50^{\prime} \mathrm{N} \\
70^{\circ} 34^{\prime} \mathrm{W}\end{array}$ & 1450 & 115- JCSC & $\mathrm{R}$ \\
\hline 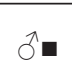 & $\begin{array}{l}\text { Barinitas [La Mina de San Isidro], } \\
\text { Nov. 1995. (Barinas) }\end{array}$ & $\begin{array}{c}8^{\circ} 50^{\prime} \mathrm{N} \\
70^{\circ} 34^{\prime} \mathrm{W}\end{array}$ & 1400 & & $\mathrm{R}$ \\
\hline$\partial \mathbf{m}^{*}$ & $\begin{array}{l}\text { Vallée du Río Santo Domingo, } 16 \\
\text { Nov. 2009. M. Costa \& S. Attal leg. } \\
\text { (Barinas) }\end{array}$ & $\begin{array}{c}8^{\circ} 50^{\prime} \mathrm{N} \\
70^{\circ} 34^{\prime} \mathrm{W}\end{array}$ & 1500 & PBB 2323 & MNHN \\
\hline
\end{tabular}


BLANDIN P. et al., Revision of the Andean Eryphanis zolvizora group

\begin{tabular}{|c|c|c|c|c|c|}
\hline \multicolumn{6}{|c|}{$\begin{array}{l}\text { Eryphanis zolvizora reyi Bristow, Neild, De Sousa \& Huertas ssp. nov. } \\
\text { VENEZUELA: Táchira, Mérida, Barinas and Lara states (continued) }\end{array}$} \\
\hline Sex & Data & Coord. & Alt. a.s.1. & Reference & Collection \\
\hline $\begin{array}{l}2 \hat{\jmath} \\
\mathbf{m}^{*} \mathbf{m}^{*}\end{array}$ & $\begin{array}{l}\text { San Isidro, Vallée du Río Santo } \\
\text { Domingo, } 9 \text { Nov. 2010. M. Costa \& S. } \\
\text { Attal leg. (Barinas) }\end{array}$ & $\begin{array}{c}8^{\circ} 50^{\prime} \mathrm{N} \\
70^{\circ} 34^{\prime} \mathrm{W}\end{array}$ & 1500 & $\begin{array}{l}\text { PBB } 2324 \\
\text { PBB } 2325\end{array}$ & MNHN \\
\hline 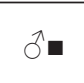 & $\begin{array}{l}\text { San Isidro, Las Minas, } 7 \text { Sep. 2002, } \\
\text { Col. Juan C. De Sousa C. (Barinas) }\end{array}$ & $\begin{array}{c}8^{\circ} 50^{\prime} \mathrm{N} \\
70^{\circ} 34^{\prime} \mathrm{W}\end{array}$ & 1475 & & $\mathrm{JCS}$ \\
\hline$\hat{0}$ & $\begin{array}{l}\text { San Isidro, Las Minas, } 10 \text { Oct. 2010, } \\
\text { Col. Mauro Costa. (Barinas) }\end{array}$ & $\begin{array}{c}8^{\circ} 50^{\prime} \mathrm{N} \\
70^{\circ} 34^{\prime} \mathrm{W}\end{array}$ & 1500 & & JCS \\
\hline$\delta$ & $\begin{array}{l}\text { San Isidro (Mina), } 4 \text { Oct. 2009, } \\
\text { (Barinas) }\end{array}$ & $\begin{array}{c}8^{\circ} 50^{\prime} \mathrm{N} \\
70^{\circ} 34^{\prime} \mathrm{W}\end{array}$ & 1500 & & $\mathrm{MCC}$ \\
\hline$\hat{O} \mathbf{m}$ & $\begin{array}{l}\text { San Isidro (Mina), } 4 \text { Oct. 2009, } \\
\text { (Barinas) }\end{array}$ & $\begin{array}{c}8^{\circ} 50^{\prime} \mathrm{N} \\
70^{\circ} 34^{\prime} \mathrm{W}\end{array}$ & 1500 & & $\mathrm{MCC}$ \\
\hline$\delta$ & $\begin{array}{l}\text { San Isidro (Mina), } 9 \text { Nov. 2009, } \\
\text { (Barinas) }\end{array}$ & $\begin{array}{c}8^{\circ} 50^{\prime} \mathrm{N} \\
70^{\circ} 34^{\prime} \mathrm{W}\end{array}$ & 1500 & & $\mathrm{MCC}$ \\
\hline$\delta$ & $\begin{array}{l}\text { San Isidro (Mina), } 12 \text { Dec. } 2009 \\
\text { (Barinas) }\end{array}$ & $\begin{array}{c}8^{\circ} 50^{\prime} \mathrm{N} \\
70^{\circ} 34^{\prime} \mathrm{W}\end{array}$ & 1500 & & $\mathrm{MCC}$ \\
\hline$\hat{\delta} \mathbf{\square}$ & La Soledad, 5 Apr. 1985 (Barinas) & $\begin{array}{c}8^{\circ} 49^{\prime} \mathrm{N} \\
70^{\circ} 31^{\prime} \mathrm{W}\end{array}$ & 1000 & & $\mathrm{MCC}$ \\
\hline$\hat{\delta} \mathbf{m}$ & $\begin{array}{l}\text { La Chimenea. 1-6 Jun. 1973, J. } \\
\text { Salcedo col. (Barinas) }\end{array}$ & $\begin{array}{c}8^{\circ} 49^{\prime} \mathrm{N} \\
70^{\circ} 31^{\prime} \mathrm{W}\end{array}$ & 1500 & & MIZA \\
\hline 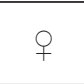 & $\begin{array}{l}\text { Barinitas [La Mina de San Isidro], Oct. } \\
1987 \text { (Barinas) }\end{array}$ & $\begin{array}{r}8^{\circ} 50^{\prime} \mathrm{N} \\
70^{\circ} 34^{\prime} \mathrm{W}\end{array}$ & 1450 & & $\mathrm{R}$ \\
\hline ○* & $\begin{array}{l}\text { Barinitas [La Mina de San Isidro], Oct. } \\
1988 \text { (Barinas) }\end{array}$ & $\begin{array}{c}8^{\circ} 50^{\prime} \mathrm{N} \\
70^{\circ} 34^{\prime} \mathrm{W}\end{array}$ & 1450 & 116-JCSC & $\mathrm{R}$ \\
\hline ㅇ & $\begin{array}{l}\text { Barinitas [La Mina de San Isidro], Oct. } \\
1988 \text { (Barinas) }\end{array}$ & $\begin{array}{c}8^{\circ} 50^{\prime} \mathrm{N} \\
70^{\circ} 34^{\prime} \mathrm{W}\end{array}$ & 1450 & & $\mathrm{R}$ \\
\hline 우 & $\begin{array}{l}\text { Barinitas [La Mina de San Isidro], } \\
\text { Nov. } 1995 \text { (Barinas) }\end{array}$ & $\begin{array}{c}8^{\circ} 50^{\prime} \mathrm{N} \\
70^{\circ} 34^{\prime} \mathrm{W}\end{array}$ & 1400 & & $\mathrm{R}$ \\
\hline ㅇ & $\begin{array}{l}\text { San Isidro [Mina], } 5 \text { Jan. } 2011 \\
\text { (Barinas) }\end{array}$ & $\begin{array}{c}8^{\circ} 50^{\prime} \mathrm{N} \\
70^{\circ} 34^{\prime} \mathrm{W}\end{array}$ & 1500 & & $\mathrm{MCC}$ \\
\hline q & $\begin{array}{l}\text { Qda. La Soledad, Via Barinitas - Sto. } \\
\text { Domingo. } 5 \text { Apr. 1985, Col. Mauro } \\
\text { Costa (Barinas) }\end{array}$ & $\begin{array}{c}8^{\circ} 49^{\prime} \mathrm{N} \\
70^{\circ} 31^{\prime} \mathrm{W}\end{array}$ & 1000 & & JCS \\
\hline q & $\begin{array}{l}\text { La Chimenea. 1-6 Jun. 1973, J.Salcedo } \\
\text { col. (Barinas) }\end{array}$ & $\begin{array}{c}8^{\circ} 49^{\prime} \mathrm{N} \\
70^{\circ} 31^{\prime} \mathrm{W}\end{array}$ & 1500 & & MIZA \\
\hline$\partial َ$ & $\begin{array}{l}\text { Anzoategui, Qda. Guazó, 13-16 } \\
\text { Jun.1972, J. Salcedo. F. Zambrano } \\
\text { (Lara) }\end{array}$ & $\begin{array}{c}9^{\circ} 36^{\prime} \mathrm{N} \\
69^{\circ} 53^{\prime} \mathrm{W}\end{array}$ & 1440 & & MIZA \\
\hline 우 & $\begin{array}{l}\text { Anzoategui, Qda. Guazó, 13-16 Jun. } \\
\text { 1972, J. Salcedo. F. Zambrano (Lara) }\end{array}$ & $\begin{array}{l}9^{\circ} 36^{\prime} \mathrm{N} \\
69^{\circ} 53^{\prime} \mathrm{W}\end{array}$ & 1440 & & MIZA \\
\hline
\end{tabular}




\begin{tabular}{|c|c|c|c|c|c|}
\hline Sex & Data & Coord. & Alt. a.s.l. & Reference & Collection \\
\hline ô* & Vía Choroní, Jun. 1970 (Aragua) & $\begin{array}{l}10^{\circ} 21^{\prime} \mathrm{N} \\
67^{\circ} 34^{\prime} \mathrm{W}\end{array}$ & 1450 & 111- JCSC & $\mathrm{R}$ \\
\hline to* & Vía Choroní, Oct. 1972 (Aragua) & $\begin{array}{l}10^{\circ} 22^{\prime} \mathrm{N} \\
67^{\circ} 35^{\prime} \mathrm{W}\end{array}$ & 1250 & 112- JCSC & $\mathrm{R}$ \\
\hline$\hat{O}$ & Vía Choroní, Sep. 1976 (Aragua) & $\begin{array}{l}10^{\circ} 22^{\prime} \mathrm{N} \\
67^{\circ} 35^{\prime} \mathrm{W}\end{array}$ & 1250 & & $\mathrm{R}$ \\
\hline ôn & Vía Choroní, Feb. 1978 (Aragua) & $\begin{array}{l}10^{\circ} 21^{\prime} \mathrm{N} \\
67^{\circ} 34^{\prime} \mathrm{W} \\
\end{array}$ & 1450 & & $\mathrm{R}$ \\
\hline ภ̄ $*$ & $\begin{array}{l}\text { Choroní, Sep. 1971. C. flia. Romero } \\
\text { (Aragua) }\end{array}$ & $\begin{array}{l}10^{\circ} 21^{\prime} \mathrm{N} \\
67^{\circ} 34^{\prime} \mathrm{W}\end{array}$ & 1450 & 117- JCSC & MIZA \\
\hline q* & Vía Choroní, Aug. 1970 (Aragua) & $\begin{array}{l}10^{\circ} 21^{\prime} \mathrm{N} \\
67^{\circ} 34^{\prime} \mathrm{W}\end{array}$ & 1550 & 113-JCSC & $\mathrm{R}$ \\
\hline ㅇ & Vía Choroní, May 1979 (Aragua) & $\begin{array}{l}10^{\circ} 22^{\prime} \mathrm{N} \\
67^{\circ} 35^{\prime} \mathrm{W}\end{array}$ & 1400 & & $\mathrm{R}$ \\
\hline q* & $\begin{array}{l}\text { Vía Choroní, cara norte, } 28 \text { Sep. } 1976 \\
\text { (Aragua) }\end{array}$ & $\begin{array}{l}10^{\circ} 22^{\prime} \mathrm{N} \\
67^{\circ} 35^{\prime} \mathrm{W} \\
\end{array}$ & 1150 & 114- JCSC & $\mathrm{R}$ \\
\hline $+*$ & $\begin{array}{l}\text { Rancho Grande, Aug. 1965, C. } \\
\text { Eduardo (Aragua) }\end{array}$ & $\begin{array}{l}10^{\circ} 20^{\prime} \mathrm{N} \\
67^{\circ} 40^{\prime} \mathrm{W} \\
\end{array}$ & 1150 & 118- JCSC & MIZA \\
\hline q & Colonia Tovar, Apr. 1993 (Aragua) & $\begin{array}{l}10^{\circ} 24^{\prime} \mathrm{N} \\
67^{\circ} 17^{\prime} \mathrm{W} \\
\end{array}$ & 2100 & & $\mathrm{R}$ \\
\hline 우 & $\begin{array}{l}\text { Colonia Tovar, via Capachal, } 2 \text { Apr. } \\
2010 \text { (Aragua) }\end{array}$ & $\begin{array}{l}10^{\circ} 24^{\prime} \mathrm{N} \\
67^{\circ} 19^{\prime} \mathrm{W} \\
\end{array}$ & 2100 & & $\mathrm{MCC}$ \\
\hline ○* & $\begin{array}{l}\text { La Llanada [Parque Nacional El } \\
\text { Ávila]. } 29 \text { Oct. } 1989 \text { (Distrito Federal) }\end{array}$ & $\begin{array}{l}10^{\circ} 33^{\prime} \mathrm{N} \\
66^{\circ} 56^{\prime} \mathrm{W}\end{array}$ & 1650 & PBB 2322 & MNHN \\
\hline
\end{tabular}

\begin{tabular}{|c|c|c|c|c|c|}
\hline \multicolumn{6}{|c|}{$\begin{array}{l}\text { Eryphanis zolvizora isabelae Neild \& De Sousa ssp. nov. } \\
\text { VENEZUELA: specimen without reliable locality }\end{array}$} \\
\hline Sex & Data & Coord. & $\begin{array}{l}\text { Alt. } \\
\text { a.s.l. }\end{array}$ & Reference & Collection \\
\hline 0 & "Mexico" & & & BMNH[E]\#808093 & BMNH \\
\hline
\end{tabular}

